\title{
Namibia: 2007 Article IV Consultation-Staff Report; Public Information Notice on the Executive Board Discussion; and Statement by the Executive Director for Namibia
}

Under Article IV of the IMF's Articles of Agreement, the IMF holds bilateral discussions with members, usually every year. In the context of the 2007 Article IV consultation with Namibia, the following documents have been released and are included in this package:

- $\quad$ The staff report for the 2007 Article IV consultation, prepared by a staff team of the IMF, following discussions that ended on January 18, 2008 with the officials of Namibia on economic developments and policies. Based on information available at the time of these discussions, the staff report was completed on January 2, 2008. The views expressed in the staff report are those of the staff team and do not necessarily reflect the views of the Executive Board of the IMF.

- $\quad$ A Public Information Notice (PIN) summarizing the views of the Executive Board as expressed during its January 18, 2008 discussion of the staff report that concluded the Article IV consultation.

- $\quad$ A statement by the Executive Director for Namibia.

The document listed below has been or will be separately released.

Selected Issues Paper and Statistical Appendix

The policy of publication of staff reports and other documents allows for the deletion of market-sensitive information.

To assist the IMF in evaluating the publication policy, reader comments are invited and may be sent by e-mail to publicationpolicy@imf.org.

Copies of this report are available to the public from

International Monetary Fund • Publication Services

$70019^{\text {th }}$ Street, N.W. • Washington, D.C. 20431

Telephone: (202) 623-7430 • Telefax: (202) 623-7201

E-mail: publications@imf.org • Internet: http://www.imf.org

Price: $\$ 18.00$ a copy

\section{International Monetary Fund Washington, D.C.}



INTERNATIONAL MONETARY FUND

NAMIBIA

\section{Staff Report for the 2007 Article IV Consultation}

Prepared by the Staff Representatives for the 2007 Consultation with Namibia

Approved by Thomas Krueger and Anthony R. Boote

January 2, 2008

- This report is based on discussions held in Windhoek November 5-16, 2007.

The staff team comprised Mr. Allum (head), Mr. Dwight, Ms. Chen (all AFR), and Mr. Oppers (MCM). Mr. Uanguta from the Executive Director's office and Mr. Burgess from the South Africa resident representative office also attended meetings.

- Meetings: Staff met with Finance Minister Kuugongelwa-Amadhila; Bank of Namibia Governor Alweendo; other senior government officials; and representatives of Parliament, the private sector, academia, development partners, and labor unions.

- Past surveillance: The 2006 Article IV, concluded in January 2007, was streamlined. Directors commended the authorities for generally prudent macroeconomic policies, recommended that they accumulate additional international reserves, and advocated market-based strategies to broaden domestic investment opportunities. The authorities have been receptive to IMF views on economic management.

- Namibia fixes its currency at par to the South African rand, which is also legal tender in Namibia. Namibia has accepted the obligations of Article VIII, Sections 2(a), 3, and 4, and maintains an exchange system free of restrictions on transfers and payments of current account transactions.

- Statistical coverage is good, but some data are not timely (Annex II).

- Selected Issues Papers are studies on (i) current account developments;

(ii) requirements for domestic investment in the pension and life insurance sector;

(iii) management of nonrenewable natural resources; and (iv) labor market issues. 


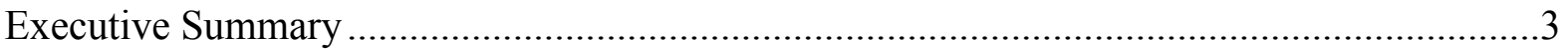

I. Economic and Financial Backdrop ...................................................................4

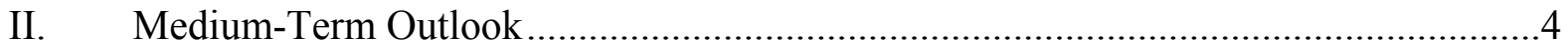

III. The Policy Discussions ....................................................................................... 10

A. How should the Emerging Fiscal Space be Used?.......................................10

B. Do Large Current Account Surpluses Signal Currency Undervaluation? .......13

C. What Further Financial Sector Reforms are Needed? ...................................17

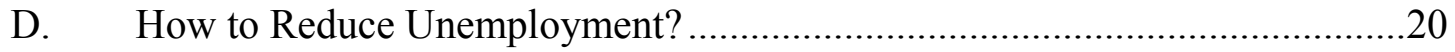

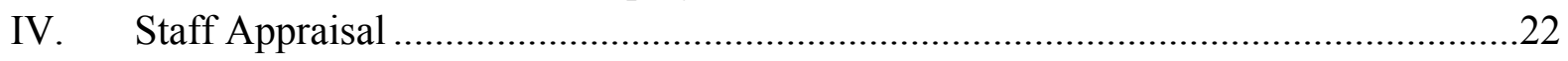

Text Tables

1. Medium-Term Macroeconomic Framework to 2012 …......................................... 9

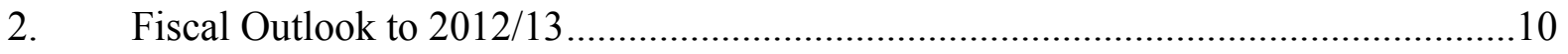

3. Savings, Investment, and the Current Account, 1990-2012 .................................15

4. Indicators of Competitiveness and Currency Valuation ...........................................15

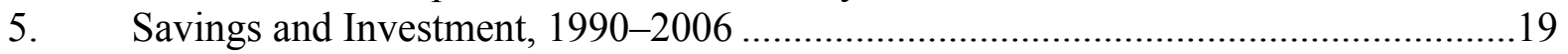

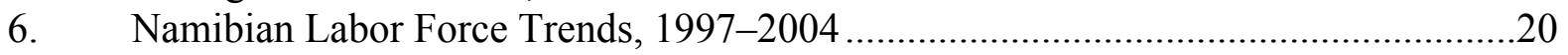

7. International Governance Indicators, 2006 ...................................................21

\section{Text Figures}

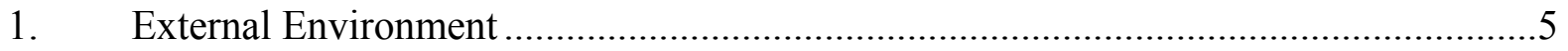

2. Fiscal Developments .....................................................................................

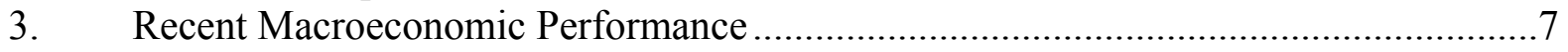

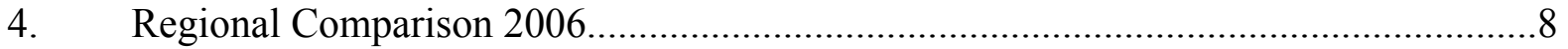

5. Progress Toward Selected Millennium Development Goals, 1990-2015 .................12

6. Savings, Investments, and the External Position .................................................. 14

7. Real Effective Exchange Rate Model, 1980-2006 ..............................................16

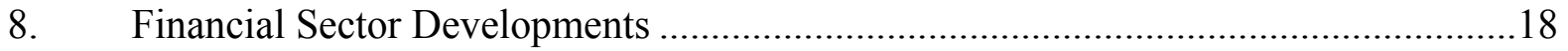

\section{Tables}

1. Selected Financial and Economic Indicators, 2003-12 .......................................24

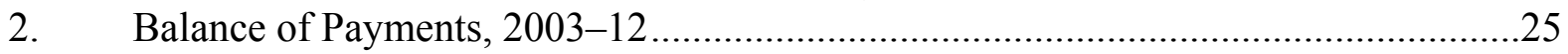

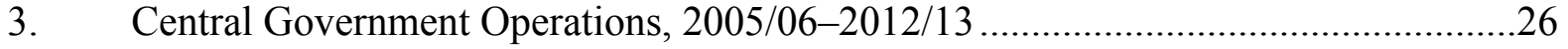

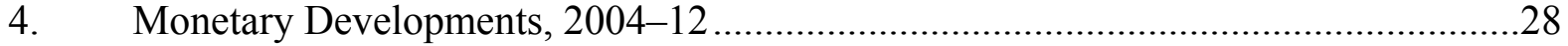

5. Millennium Development Goals, 1990-2005 ...................................................29

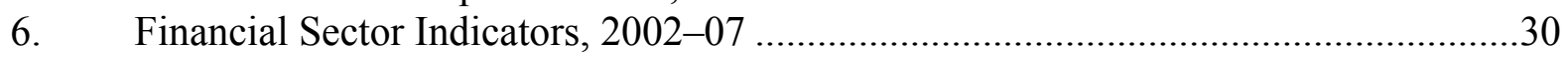

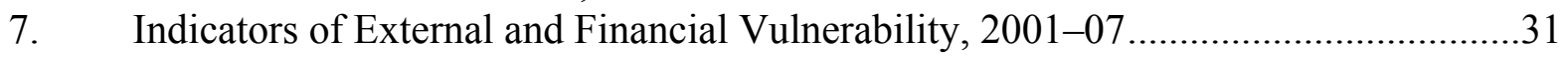

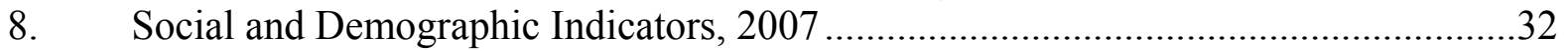




\section{EXECUTIVE SUMMARY}

\section{Background}

Namibia's economic position has been reinforced since the last consultation. Real GDP growth is in line with regional performance, and a substantial terms of trade improvement and large receipts from the Southern Africa Customs Union (SACU) have contributed to significant external current account and fiscal surpluses. Official reserves have increased to a comfortable level, and it is expected that public debt will be reduced to less than 25 percent of GDP this year.

The economic outlook is generally good, despite a projected partial reversal of the terms of trade gains and prospects for lower SACU receipts relative to GDP. The biggest economic problems are unemployment and poverty.

\section{Policy discussions}

Staff supported the authorities' strategy of broadening the economic base and reducing unemployment while preserving a solid fiscal position.

Staff endorsed the authorities' intent to increase infrastructure spending, using existing fiscal space and reprioritizing expenditures. There was also agreement on the importance of reinvigorating domestic revenue administration, given the potential vulnerability of SACU receipts.

Staff supports Namibia's intention to ensure that interest rate differentials with South Africa do not destabilize official reserves or capital flows within the common monetary area (CMA). The authorities are committed to the CMA.

Notwithstanding increased current account surpluses, there was agreement that there is no clear evidence of significant currency undervaluation. To build competitiveness in the nonmining sector, measures to develop skills and enhance labor productivity will be important.

The banking system is profitable and well-capitalized, and there has been welcome progress in reinforcing financial sector supervision in line with FSAP recommendations. The authorities are aware of the risks of tightening domestic investment requirements for the pension and insurance sectors; staff recommended a careful phase-in, and efforts to broaden the investment options.

Staff supported Namibia's efforts to increase employment opportunities in the nonmining economy by, e.g., making the labor market more flexible. Staff also recommended continuing liberalization of the trade regime, including through broader free trade arrangements. 


\section{ECONOMIC AND FINANCIAL BACKDROP}

1. Namibia is benefiting from a favorable external environment:

- $\quad$ The terms of trade strengthened by an estimated one-third between 2005 and 2007 on high mineral export prices. Improved diamond extraction rates and rising SACU receipts driven by South African import growth also contributed to an external current account surplus estimated at 16-18 percent of GDP in 2006 and 2007 (Figure 1).

- $\quad$ A fiscal surplus of 3.4 percent of GDP was recorded in 2006/07 because of high SACU receipts and tight spending policies. For 2007/08, a surplus of 2.6 percent is projected, which should reduce public debt to 23 percent of GDP (Figure 2).

- $\quad$ Net international reserves have almost doubled since 2005 as part of the increased SACU receipts was saved. At end-September 2007 gross reserves of $\$ 850$ million matched short-term external debt, were more than three times base money, and represented 3.0 months of imports of goods and services.

- Inflation remains modest despite pressures from higher international food prices; it declined to 6.6 percent in October 2007 from a peak of 7.2 percent in July (Figure 3). To contain inflationary pass-through, since mid-2006 interest rates have been increased 3.5 percentage points (to 10.5 percent). Treasury bill yields have edged below South African rates reflecting a declining supply with the strengthened fiscal position.

- $\quad$ The exchange rate has been stable in nominal effective terms in the 12 months through September 2007, and the real effective exchange rate in the first nine months of 2007 was in line with the average for the preceding decade (Figure 1).

- $\quad$ Real GDP growth matches regional peers, and Namibia shares the same challenges with regard to unemployment and the prevalence of HIV (Figure 4).

\section{MediUM-TERM OUTLOOK}

\section{The medium-term outlook is promising:}

- $\quad$ Real GDP growth per capita is projected to approach 4 percent, up from 3 percent a few years ago. This reflects a continued strengthening of the nonmining economy, which accounts for 85 percent of GDP. The timing and yields from exploiting the Kudu natural gas field are uncertain and could boost growth toward 2012.

- Inflation is projected to decline to 5.5 percent by 2009; tighter monetary policies are already in place. A small positive differential between Namibian and South African inflation is projected because productivity in Namibia continues to grow faster, so inflation is at the upper end rather than the center of South Africa's 3-6 percent target range.

\footnotetext{
${ }^{1}$ The fiscal year is April 1-March 31.
} 
Figure 1. Namibia: External Environment

Namibia is a relatively open economy...

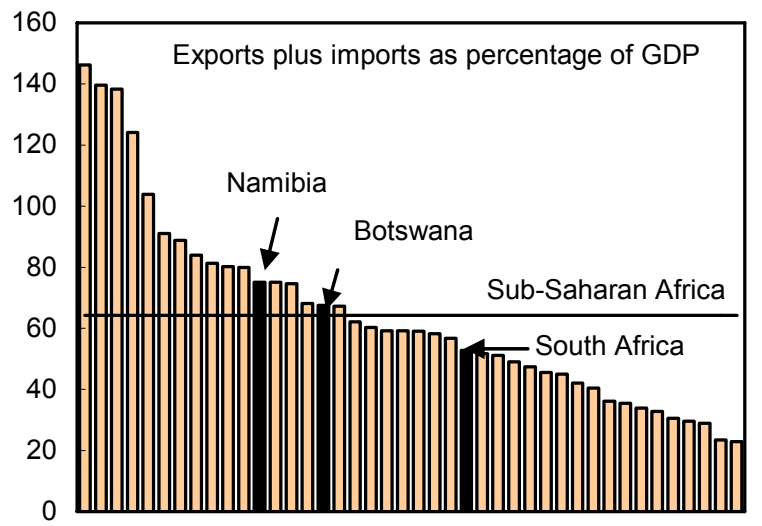

Namibia's terms of trade have risen sharply, ...

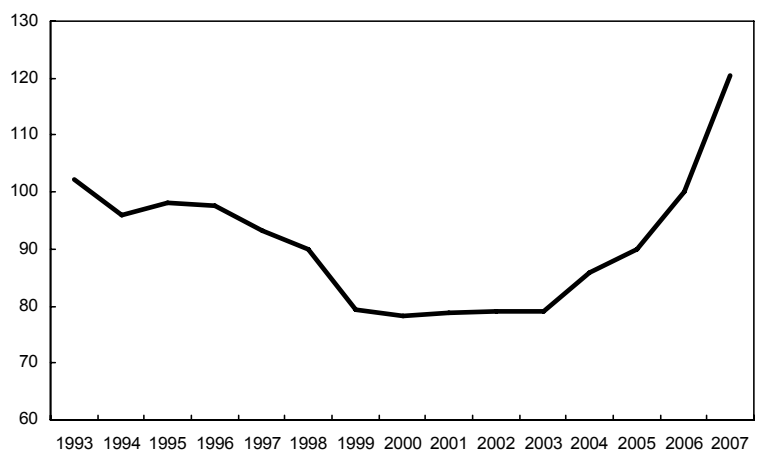

...and a larger current account surplus.

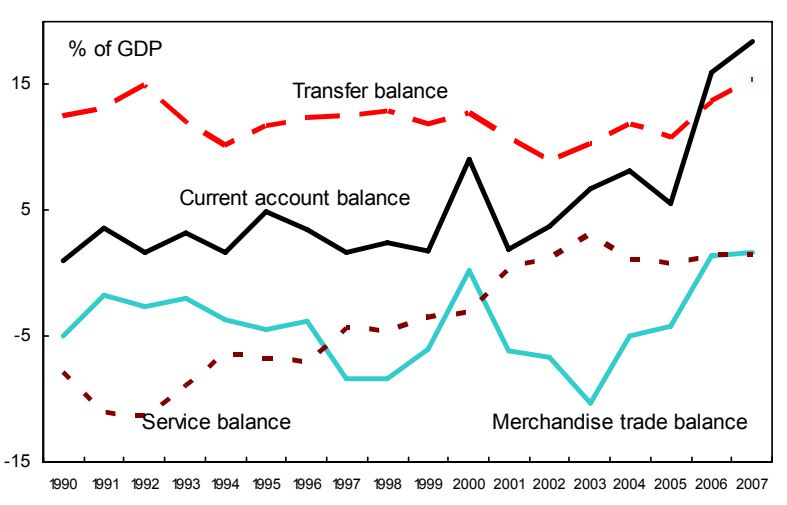

Source: IMF staff estimates. ...where minerals account for more than half of exports.

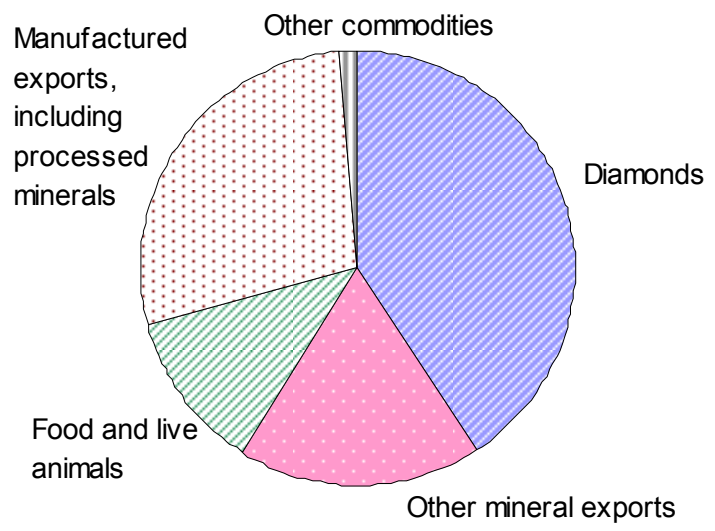

...boosting mineral exports and contributing to a merchandise trade surplus ...

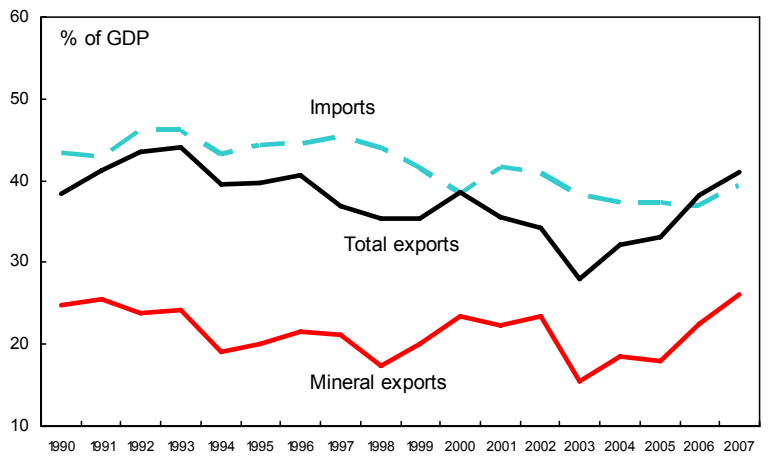

Namibia's real effective exchange rate is at its 1990-2005 average.

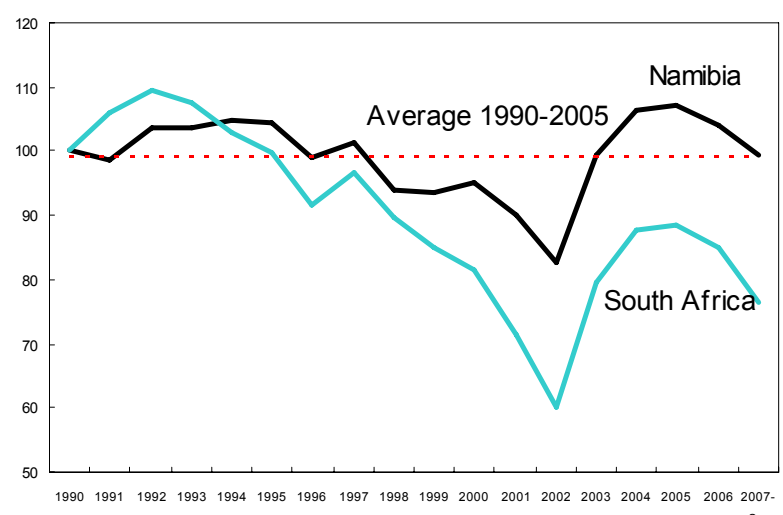


Figure 2. Namibia: Fiscal Developments

Namibia had one of the strongest fiscal positions in Africa in 2006 ...

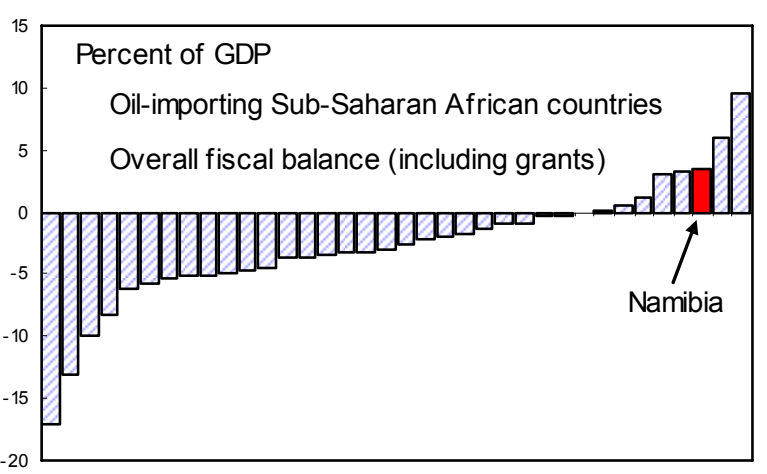

\section{Revenues benefited from higher mineral taxes and SACU transfers ...}

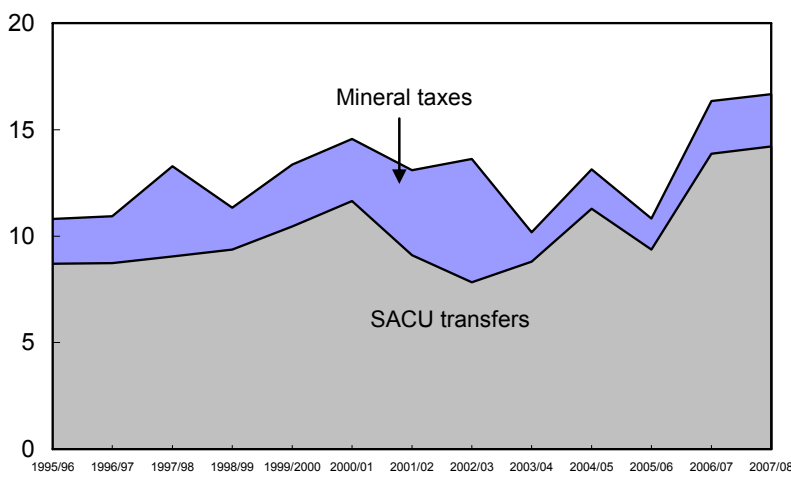

Excluding SACU transfers and mining, the fiscal stance has eased.

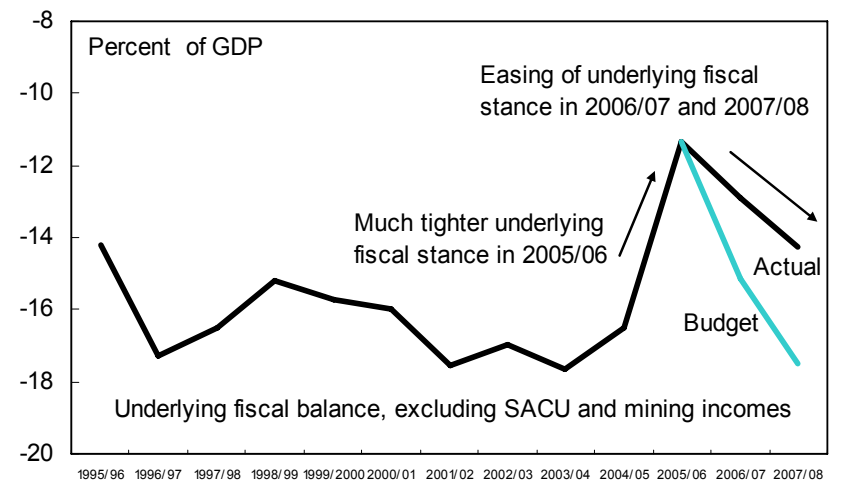

Sources: Namibian authorities; and IMF staff estimates.
... reflecting both revenue growth and expenditure compression.

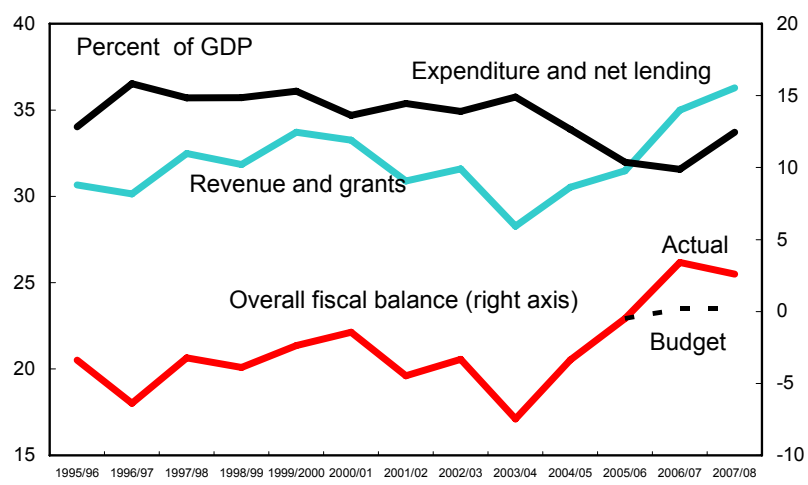

... and public debt was reduced below its ceiling

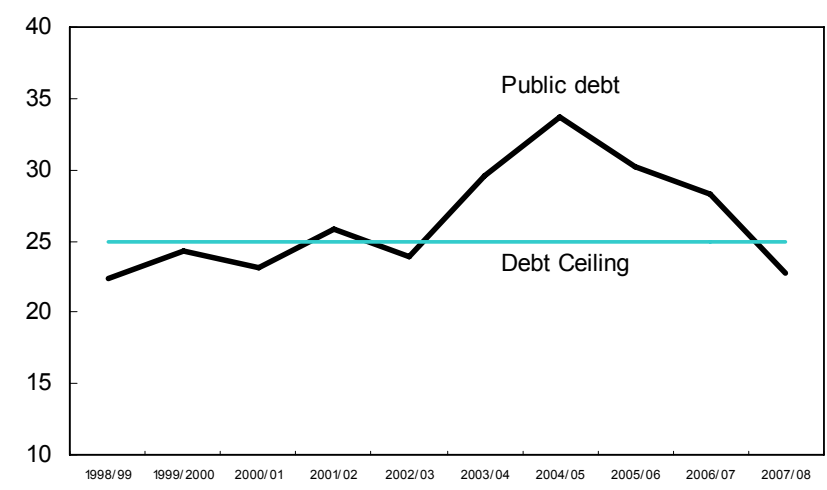

Personnel expenditure remains high.

2006

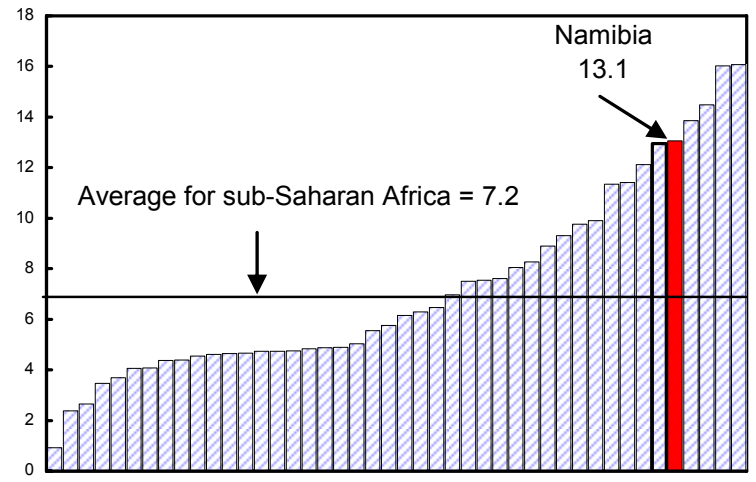


Figure 3. Namibia: Recent Macroeconomic Performance

Per capita income growth has strengthened ...

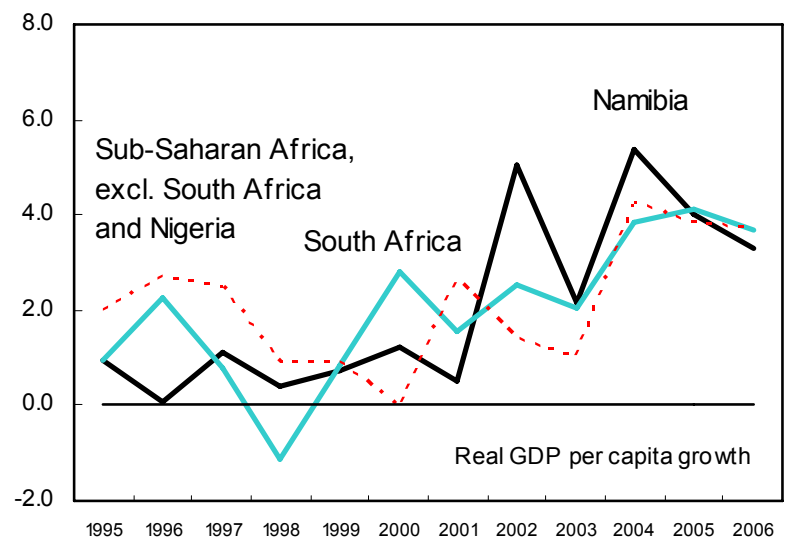

Namibia's inflation parallels South Africa's ...

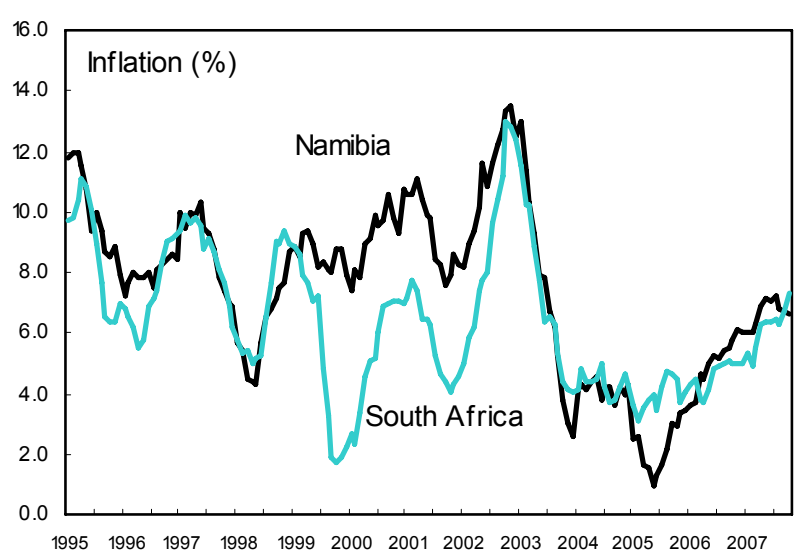

Private sector investment remains high, ...

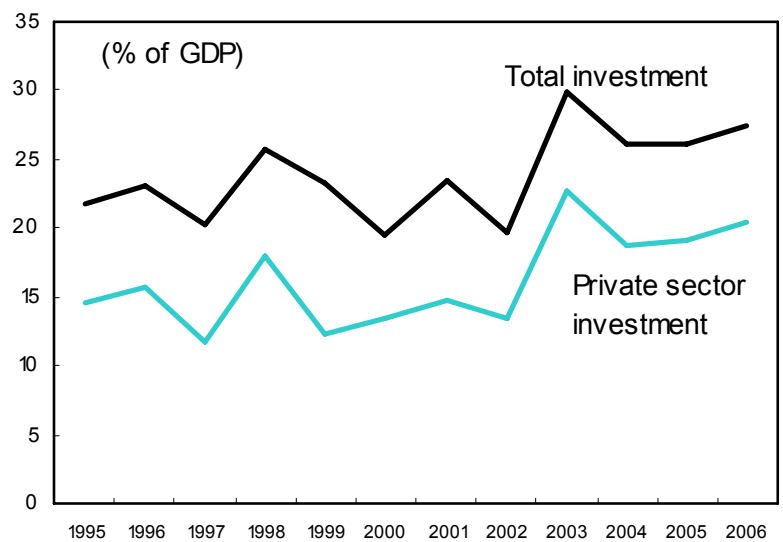

Sources: Namibian authorities; and IMF staff estimates. ...with generally higher nonmining growth since 2002.

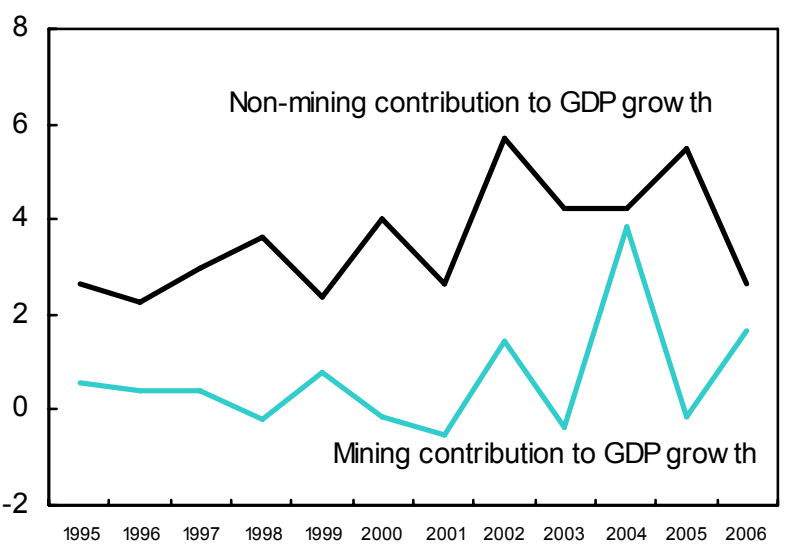

... but has declined since July.

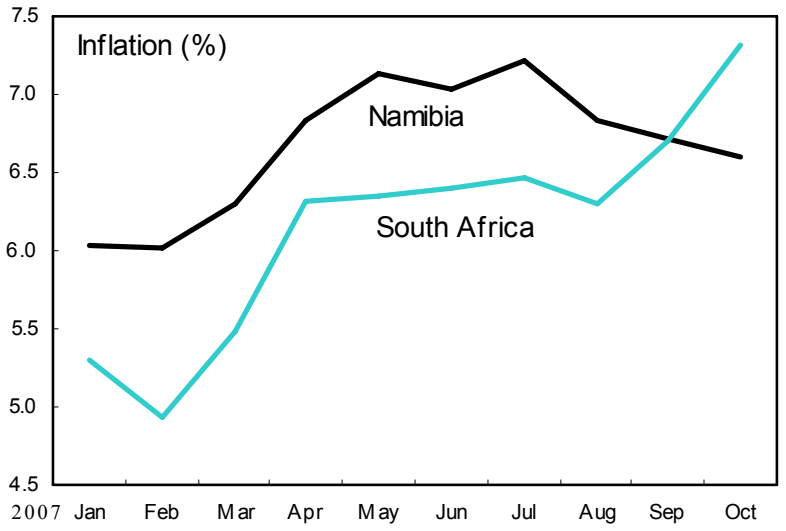

... reflecting in part strong FDI inflows.

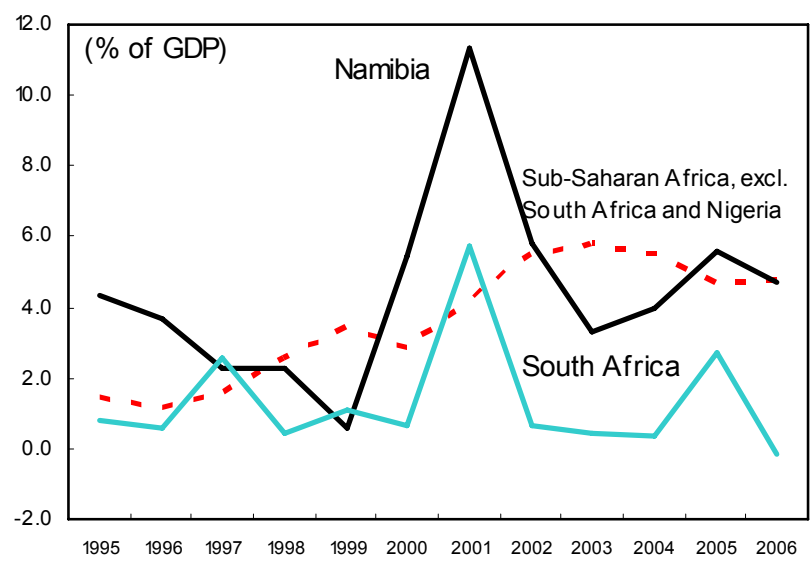


Figure 4. Namibia: Regional Comparison 2006

GDP growth ...

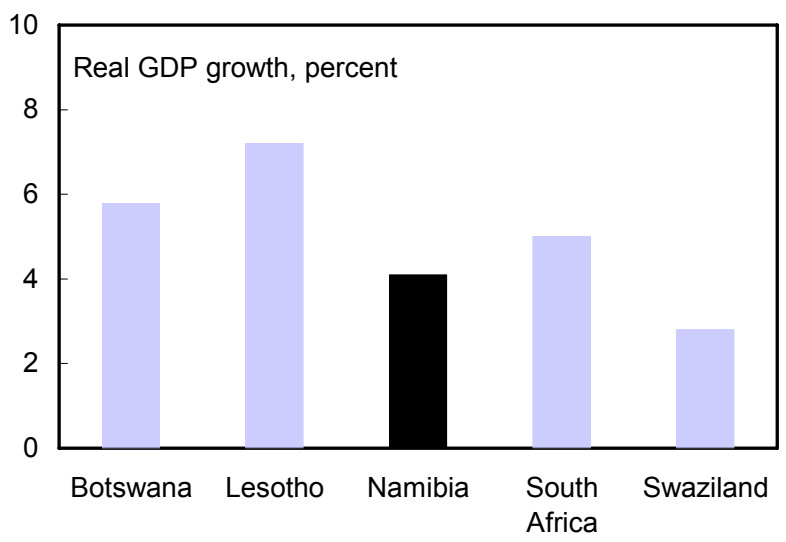

While the fiscal surplus lags due to larger SACU contributions in other countries ...

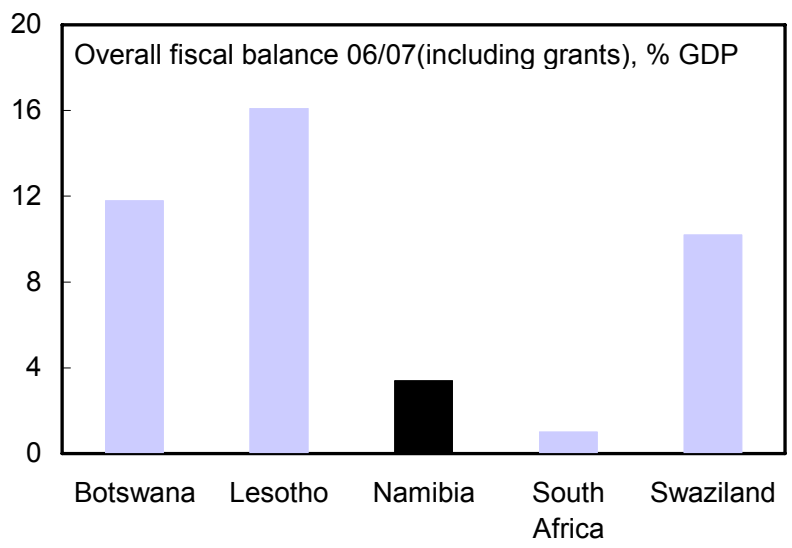

Namibia, together with South Africa, has a relatively deep financial system.

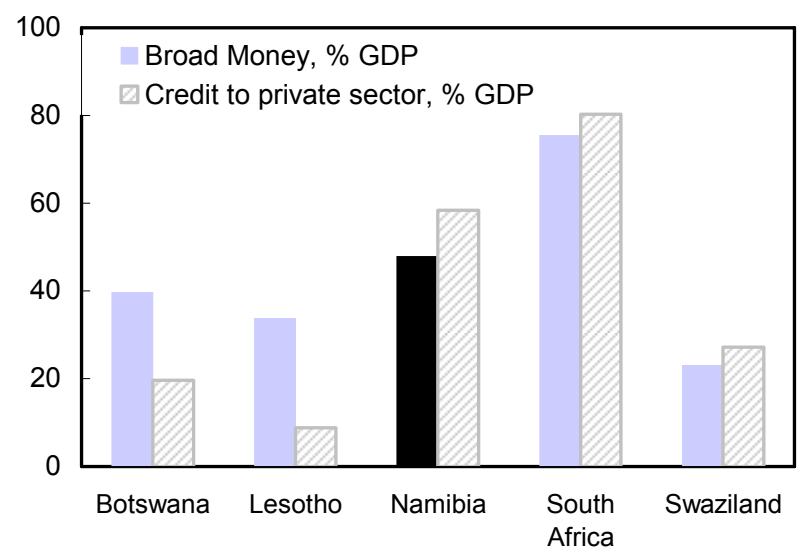

Source: IMF staff estimates.
... and inflation are in line with regional peers.

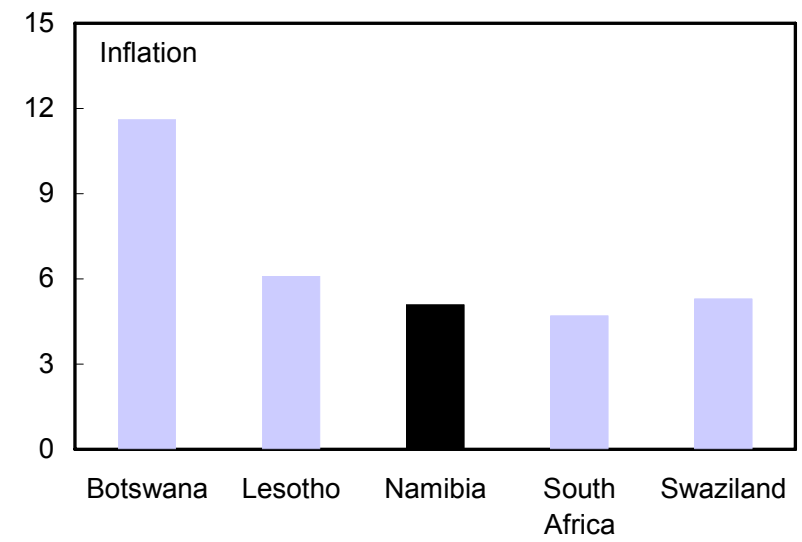

... Namibia's current account is one of the strongest.

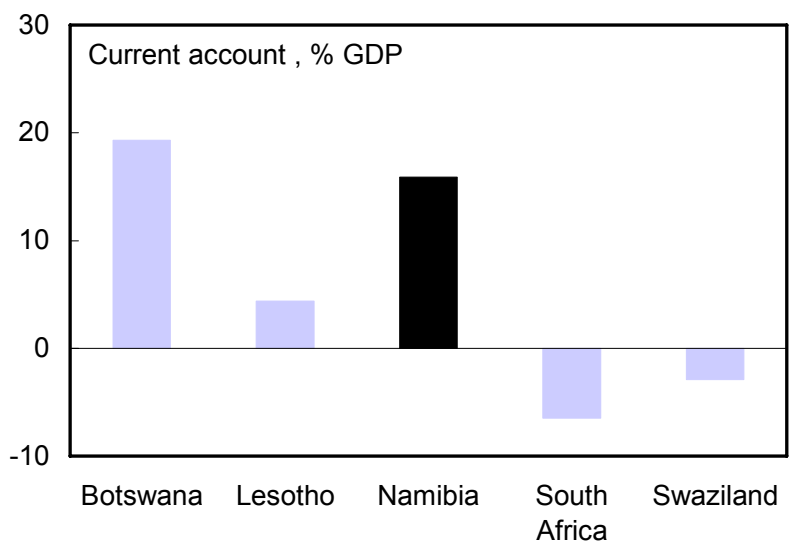

Unemployment and HIVIAIDS are regional challenges.

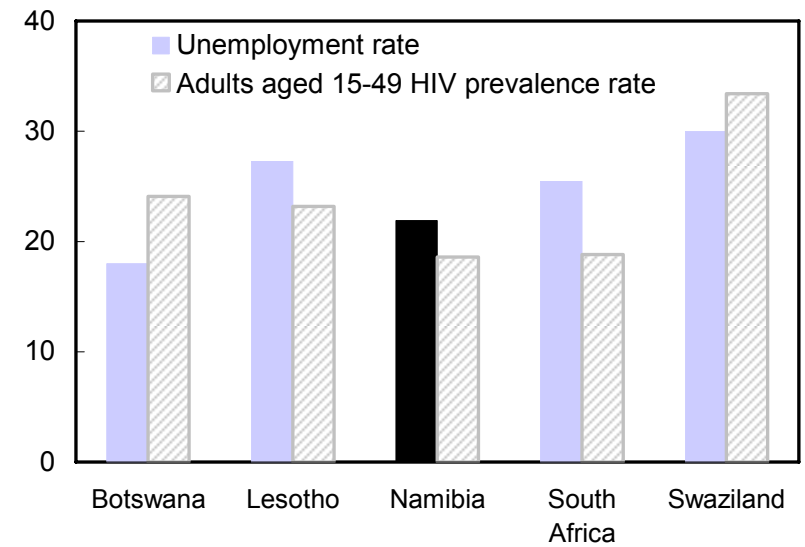


- $\quad$ Private sector credit should continue to exceed nominal GDP growth, financing rising investments. As private savings decline from peak levels, the external current account surplus is projected to narrow.

Medium-Term Macroeconomic Framework to 2012

\begin{tabular}{lrrrrrr}
\hline & $\mathbf{2 0 0 0 - 0 5}$ & $\mathbf{2 0 0 6}$ & $\mathbf{2 0 0 7}$ & $\mathbf{2 0 0 8}$ & $\mathbf{2 0 0 9}$ & $\mathbf{2 0 1 2}$ \\
\hline & \multicolumn{7}{c}{ (Percentage changes) } \\
Real GDP growth & 4.6 & 4.1 & 4.4 & 4.8 & 4.5 & 4.8 \\
$\quad$ Mining & 6.5 & 15.4 & 1.4 & 6.8 & -1.2 & 0.8 \\
Nonmining & 4.5 & 3.0 & 4.7 & 4.6 & 5.1 & 5.2 \\
Real GDP per capita growth & 3.0 & 3.2 & 3.5 & 3.9 & 3.6 & 4.0 \\
CPI inflation (end-period) & 7.0 & 6.0 & 6.7 & 5.7 & 5.5 & 5.5 \\
& \multicolumn{7}{c}{ (Percent of GDP) } \\
Gross investment & 24.1 & 27.5 & 28.2 & 29.8 & 31.2 & 32.1 \\
Gross national savings & 30.0 & 43.4 & 46.7 & 42.4 & 40.9 & 37.5 \\
$\quad$ Public & 1.8 & 7.8 & 9.4 & 8.3 & 7.4 & 6.7 \\
$\quad$ Private & 28.1 & 35.7 & 37.3 & 34.1 & 33.5 & 30.8 \\
External current account balance & 5.8 & 15.9 & 18.5 & 12.6 & 9.7 & 5.4 \\
\hline
\end{tabular}

Sources: Namibian authorities; and IMF staff projections.

\section{There are risks related to mineral production, diversification into nonmineral activities, and SACU receipts.}

- $\quad$ Mining sector volatility is such that the terms of trade may decline faster than projected over the medium term.

- $\quad$ Business climate and public infrastructure improvements may fall short of what is needed to support investment and growth projections.

- $\quad$ Political and social risk: As baseline growth projections would reduce unemployment and income inequality only marginally at first, they would remain as political and social concerns.

- SACU receipts are projected at 11-12 percent of GDP over the medium term, financing about one-third of public spending. These receipts are vulnerable to revision of the revenue-sharing formula, an issue already tabled for discussion.

4. Upside risks relate primarily to the pace of structural reform. Decisive steps to make the labor market more flexible and eliminate business impediments could accelerate economic diversification and reduce unemployment more meaningfully.

5. The authorities concurred with this analysis. Preliminary Bank of Namibia projections for annual economic growth were up to 0.5 percent lower than those of staff, based on more cautious assumptions about the capacity to extend diamond extraction through new discoveries and developments in extraction technology. At the same time, with large parts of the country unsurveyed, the authorities see new mineral discoveries as a distinct possibility. 


\section{The Policy Discussions}

\section{A. How Should the Emerging Fiscal Space be Used?}

\section{Background}

\section{Increased receipts from SACU and the mining sector have created fiscal space.}

- $\quad$ The 25 percent of GDP debt ceiling is likely to be undershot by 2 percentage points this fiscal year. With a strong primary balance, the budget is well-placed to weather declines in SACU and mining revenues over the medium term without breaching the debt ceiling.

- $\quad$ The emerging fiscal space could be used to keep public debt below the ceiling, reduce taxes, or accommodate new spending. Given relatively low public debt and credible fiscal management, the case for maintaining a margin below the debt ceiling is not persuasive. Reducing taxes is also risky, given SACU receipt vulnerabilities. Accordingly, the macroeconomic framework developed with the authorities incorporates a modest expenditure increase, primarily for infrastructure, that amounts to a cumulative $4 \frac{1}{2}$ percent of GDP over five years.

Fiscal Outlook to 2012/13

(Percent of GDP)

\begin{tabular}{lrrrrrrr}
\hline & $\mathbf{2 0 0 5 / 0 6}$ & $\mathbf{2 0 0 6 / 0 7}$ & $\mathbf{2 0 0 7 / 0 8}$ & $\mathbf{2 0 0 8 / 0 9}$ & $\mathbf{2 0 0 9 / 1 0}$ & $\mathbf{2 0 1 0 / 1 1}$ & $\mathbf{2 0 1 2 / 1 3}$ \\
\hline Revenues and grants & 31.5 & 35.0 & 36.3 & 34.7 & 33.9 & 33.6 & 33.3 \\
SACU transfers & 9.4 & 13.9 & 14.2 & 12.8 & 12.1 & 11.8 & 11.4 \\
Mining revenues & 1.5 & 2.5 & 2.5 & 2.5 & 2.3 & 2.2 & 2.2 \\
Other & 20.7 & 18.6 & 19.6 & 19.4 & 19.6 & 19.6 & 19.7 \\
Expenditures & 32.0 & 31.6 & 33.7 & 34.6 & 35.2 & 35.1 & 34.6 \\
Current expenditures & 28.0 & 25.9 & 26.8 & 26.8 & 26.7 & 26.6 & 26.6 \\
Capital expend. and net lending & 4.0 & 5.6 & 6.9 & 7.8 & 8.5 & 8.5 & 8.0 \\
Overall balance & -0.5 & 3.4 & 2.6 & 0.1 & -1.3 & -1.5 & -1.3 \\
$\quad$ Less SACU and mineral taxes & -11.3 & -12.9 & -14.1 & -15.2 & -15.6 & -15.5 & -14.9 \\
Public debt & 30.2 & 28.2 & 22.8 & 22.5 & 23.5 & 24.5 & 25.0 \\
\hline
\end{tabular}

Sources: Namibian authorities; and IMF staff projections.

7. Given uncertainties about future SACU financing, the tax administration effort must be more ambitious. The Inland Revenue Department (IRD) needs a strategic plan setting out goals and work priorities, supported by stepped-up recruitment and capacity building. Forensic tax audits are currently contracted to private accounting companies rather than IRD staff; there is no effective large-taxpayer unit; and VAT refunds are audited in a comprehensive rather than risk-based manner. 
8. The quality of public spending could be improved:

- $\quad$ Public spending is high by sub-Saharan African standards, and better prioritization could accelerate poverty reduction and progress toward the Millennium Development Goals (Figure 5).

- $\quad$ Program-based budgeting is a first priority. Expenditure data are currently reported only by line ministry, and a modernized chart of accounts is needed to support informed discussion of spending priorities.

- $\quad$ The public wage bill in relation to GDP is one of the highest in Africa. Although it was reduced from 15 percent of GDP three years ago to 13 percent in 2006/07 (Figure 2), what is needed is a strategy for civil service structure, performance, and remuneration.

- $\quad$ State-owned enterprises (SOEs) continue to jeopardize the budget. An SOE Governance Act approved in August 2006 is stalled pending establishment of an oversight secretariat. Because of public opposition no significant privatizations are planned.

- $\quad$ The new medium-term expenditure framework (MTEF) offers a basis for prioritizing spending but could be more effective. Spending decisions should be based on the revenue outlook beyond potentially temporary SACU, mining, and other receipts. Budget surpluses and debt reduction in periods of peak income would provide room to sustain spending when public revenues fall. Although recent fiscal surpluses seem consistent with this approach, they reflect shortfalls in capital spending and unexpectedly strong nominal income growth as much as fiscal discipline.

\section{Policy discussions}

\section{Ministry of Finance (MoF) officials underlined the importance of firm fiscal} stewardship. They confirmed the central role of the MTEF in ensuring fiscal sustainability but also noted political challenges in programming fiscal surpluses when revenue is growing given the country's unmet social and economic needs. They continue to see the public debt limit as a central fiscal anchor and will work to ensure that it continues to be respected.

10. Government officials recognized the need to redouble their efforts to strengthen tax administration to mobilize domestic revenue. However, they cited poor taxpayer compliance and recruitment and retention issues in IRD as factors behind the decision to adopt intensive audits of VAT returns and outsource forensic tax audits. Staff saw the intention to mobilize more domestic revenue as welcome, compared to the modest decline relative to GDP projected in the last MTEF. The government intends to seek IMF technical assistance to review the adequacy of taxation of the mining sector considering increased 
Figure 5. Namibia: Progress Toward Selected Millennium Development Goals, 1990-2015 1/ (In percent, unless otherwise indicated)

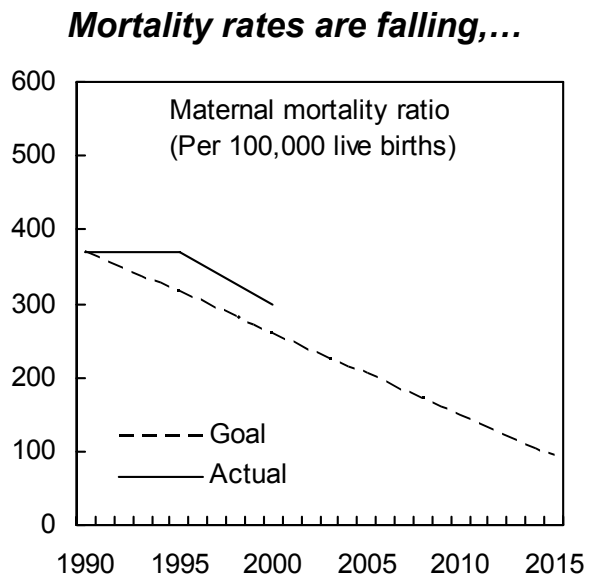

Female school enrollment is high...

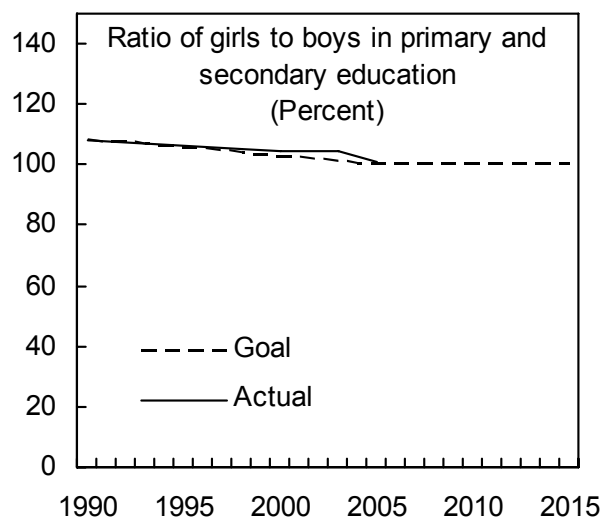

Access to water supplies is rising.

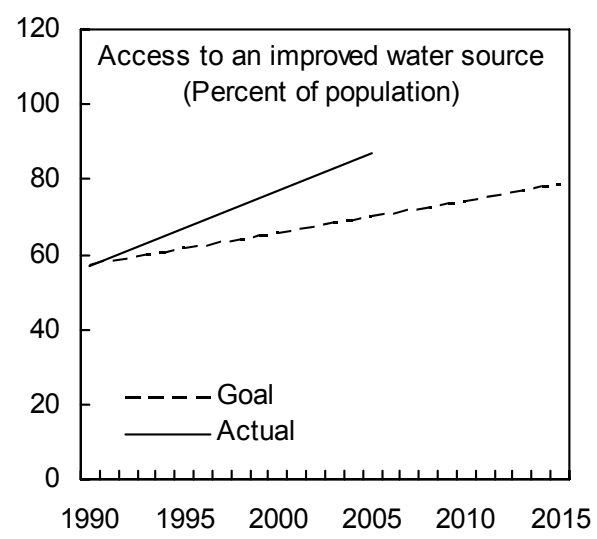

...but lag the MDG targets.

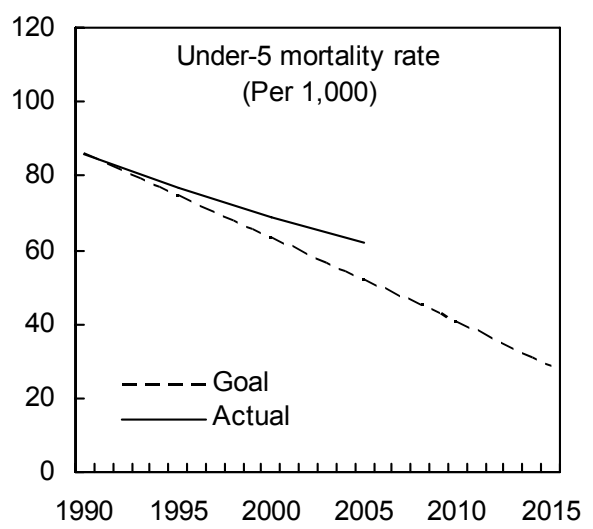

...but overall enrollment lags the MDG targets.

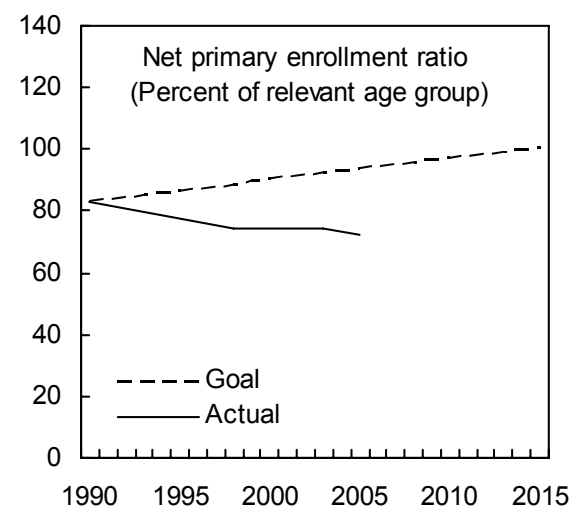

But nutrition performance is lagging.

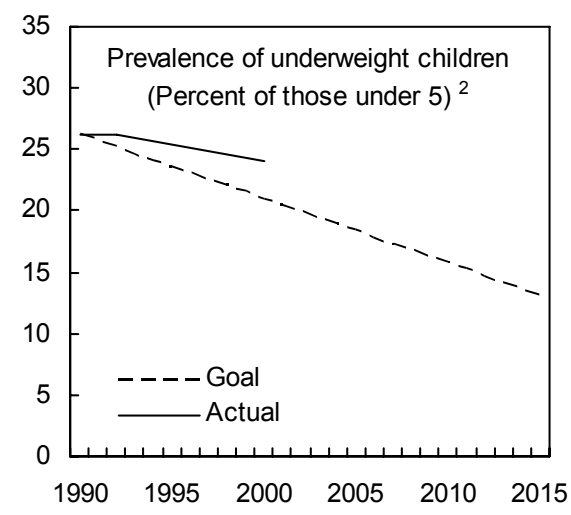

Sources: World Bank, http://www.developmentgoals.org; and United Nations, http://unstats.un.org. 1/ Progress is measured compared to a linear projection between the 1990 level and the end year goal. 2/ Actual data for 1990 is assumed to be equal to 1992 level, due to lack of data. 
mining sector rents and new investments. ${ }^{2}$ The authorities are also considering staff recommendations that Namibia subscribe to the Extractive Industry Transparency Initiative (EITI). ${ }^{3}$ Staff noted that proposals to delegate some revenues and expenditures to subnational authorities should be crafted carefully to avoid undermining fiscal management.

\section{The authorities confirmed the need for better prioritization of spending. They} intend to use the emerging fiscal space to fund growth-promoting infrastructure (notably roads, rail, and rural electrification) and sectoral programs (tourism and fisheries). They indicated that program-based budgeting is a high priority and will continue to control the public wage bill. They also noted that they are considering the use of public-private partnerships to make public spending more effective. In welcoming these goals, staff encouraged the authorities to bring the SOE Act into effect. Noting the contributions of the Global Fund, the United States, and other donors to Namibia's successful antiretroviral (ART) drug program, staff also suggested that a progressive increase in Namibia's own contribution would help ensure sustainability. ${ }^{4}$ The authorities responded that while the budget covered other aspects of the pandemic, provision for antiretrovirals would be increased as needed.

\section{B. Do Large Current Account Surpluses Signal Currency Undervaluation?}

\section{Background}

\section{Namibia's very large current account surpluses reflect a combination of temporary fiscal tightening and an increase in private savings: ${ }^{5}$}

- Public savings rose more than 6 percent in 2006, accounting for three-quarters of the rise in the current account surplus compared to the three preceding years. ${ }^{6}$

- $\quad$ Private savings have also risen considerably since 2003. Though not well understood this trend coincides with a decline in inflation (Figure 6). ${ }^{7}$

\footnotetext{
2 This would be consistent with Namibia's participation as a pilot case for closer Bank-Fund collaboration in supporting management of natural resource earnings.

${ }^{3}$ Namibia is currently a participant in the Kimberley Process diamonds initiative.

${ }^{4}$ Namibia's HIV prevalence rate declined from 22 percent in 2002 to 20 percent in 2006. A program for public provision of ART drugs was launched in mid-2003, and now covers about 40,000 patients, or about 70 percent of those who could benefit from ART treatment.

${ }^{5}$ A more detailed discussion of these issues is provided in the accompanying selected issues paper.

${ }^{6}$ Recent fiscal revenues from the diamond sector, Namibia's principal mineral export, have been 1-2 percent of GDP, compared to an estimated "permanent" fiscal income from diamonds of about 0.4 percent of GDP, taking into account depletion prospects. This difference is not sufficiently large to merit sustained high public savings for income smoothing purposes.

${ }^{7}$ There is a significant inverse relationship between private savings and inflation for 1990-2006.
} 
Figure 6. Namibia: Savings, Investment, and the External Position

\section{A large current account surplus reflects high savings ...}

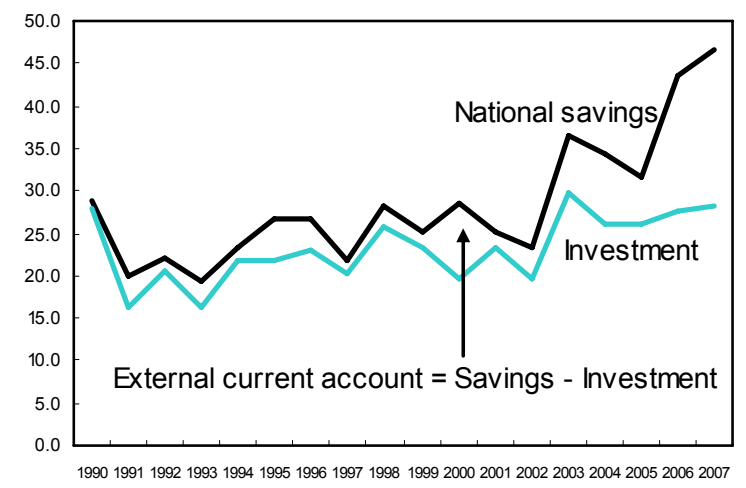

\section{Savings in 2006/07 reflect SACU and mining windfalls ...}

Comparing $2006-07$ to the previous three years: $\%$ of GDP)

The increased current account surplus...

largely reflects increased savings.

Public savings have risen, partly due to...

higher SACU transfers and...

increased mining taxes.

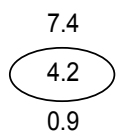

Larger private savings notably reflect...

$\underline{\text { mining windfalls. }}$

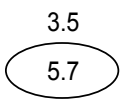

\section{Savings have boosted capital outflows,...}

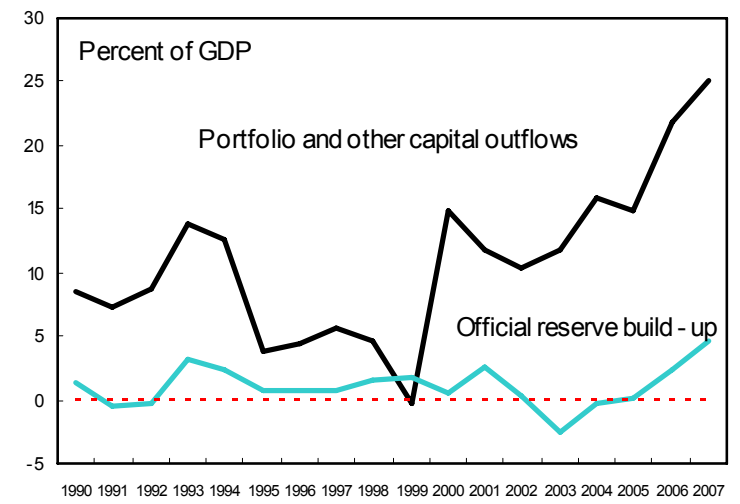

... by both the public and private sectors.

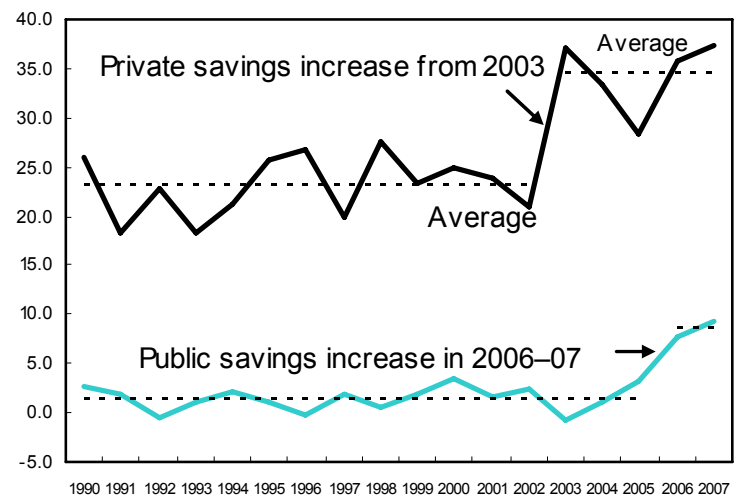

... and, since 2003, a decline in inflation.

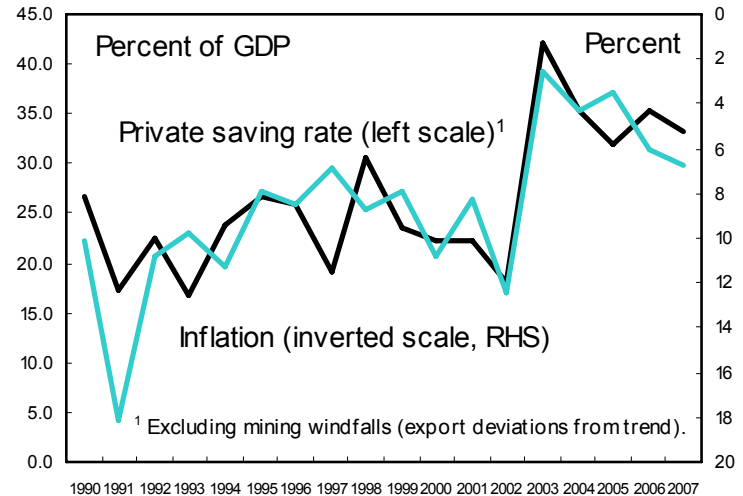

... which remain a small part of South Africa's external financing.

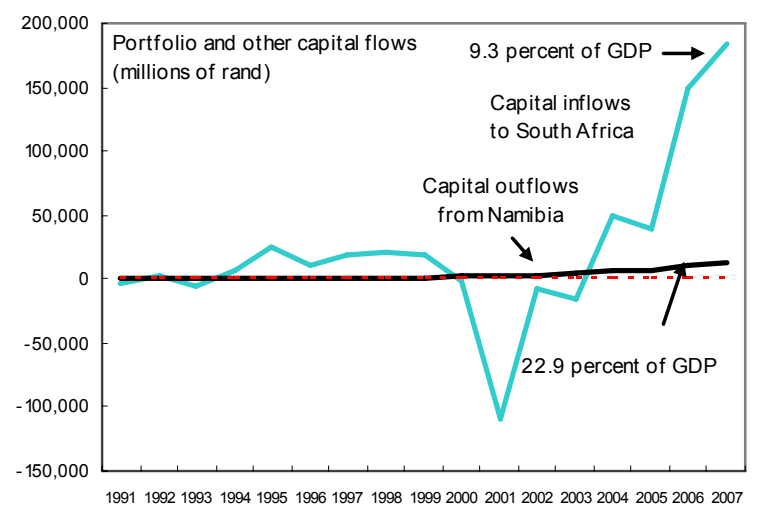

Sources: Namibian authorities; and IMF staff estimates. 
- $\quad$ Mining sector: The increase in private savings in 2006 may reflect increased mining incomes. Mineral exports rose by 4 percent of GDP in 2006, and although mining operations are largely foreign-owned, these increased incomes may have boosted recorded savings pending payment of taxes and remittance of dividends. Absent corporate income data, this channel is difficult to quantify.

- Net foreign assets: Much of the additional savings have been invested abroad, and the medium-term projections for savings-investment balances are consistent with stabilization of private sector net foreign assets at a higher level.

Savings, Investment, and the Current Account, 1990-2012 (Percent of GDP)

\begin{tabular}{lccccc}
\hline & $\begin{array}{c}\text { Public } \\
\text { Savings }\end{array}$ & $\begin{array}{c}\text { Public } \\
\text { Investment }\end{array}$ & $\begin{array}{c}\text { Private } \\
\text { Savings }\end{array}$ & $\begin{array}{c}\text { Private } \\
\text { Investment }\end{array}$ & $\begin{array}{c}\text { Current } \\
\text { Account }\end{array}$ \\
\hline $1990-2002$ & 1.5 & 7.7 & 23.1 & 13.8 & 3.1 \\
$2003-2005$ & 1.2 & 7.1 & 33.0 & 20.3 & 6.8 \\
2006 & 7.8 & 7.0 & 35.7 & 20.5 & 15.9 \\
2012 & 6.7 & 10.1 & 30.8 & 22.0 & 5.4 \\
\hline
\end{tabular}

Sources: Namibian authorities; and IMF staff projections.

\section{Yet there is no conclusive evidence of significant undervaluation:}

- $\quad$ Tradables sector performance (aside from mining) is weak, which is at odds with a possible currency undervaluation. Manufacturing growth has declined since 2003, as has real GDP growth. There is no evidence of a sustained pick up in nonmineral exports or a slowing in import demand.

- $\quad$ Survey-based competitiveness indicators have deteriorated on some measures since the 1990s; while the trend is not significant, it does not a priori suggest accelerated supply-side improvements that would lead to currency appreciation.

\section{Indicators of Competitiveness and Currency Valuation}

\begin{tabular}{|c|c|c|c|c|}
\hline & 1990-2002 & $2003-05$ & 2006 & 2007 \\
\hline \multicolumn{5}{|c|}{ (percent changes from a year earlier) } \\
\hline Manufacturing sector value-added & 4.2 & 3.4 & -8.3 & $\ldots$ \\
\hline Real GDP & 5.4 & 5.0 & 4.1 & $\ldots$ \\
\hline Nonmineral export values $(\$)^{1}$ & -8.0 & 36.5 & -22.0 & $\ldots$ \\
\hline Import volumes $^{2}$ & -2.7 & 18.2 & 6.3 & $\cdots$ \\
\hline \multicolumn{5}{|c|}{ (levels) } \\
\hline Inflation differential w/South Africa ${ }^{3}$ & 1.3 & 1.0 & 0.4 & -1.0 \\
\hline Inflation differential w/trading partners ${ }^{3}$ & 4.5 & 1.8 & 1.8 & 2.7 \\
\hline Government effectiveness $^{4}$ & 66.0 & 60.5 & 59.2 & $\ldots$ \\
\hline
\end{tabular}


- Behavioral real exchange rate models suggest emerging undervaluation estimated at about 7-8 percent in $2006^{8}$ (Figure 7) - but the models also predict that about half of this undervaluation would pass through to higher inflation differentials within a year. While inflation has picked up relative to trading partners, the increase has been modest, consistent with a small undervaluation.

\section{Policy discussions}

\section{The authorities underlined their commitment to the common monetary area}

(CMA). ${ }^{9}$ They agreed that there is no clear evidence of significant currency undervaluation. Indeed (see below), their main concern was the need to make nonmineral exports more competitive.

Figure 7. Real Effective Exchange Rate Model, 1980-2006

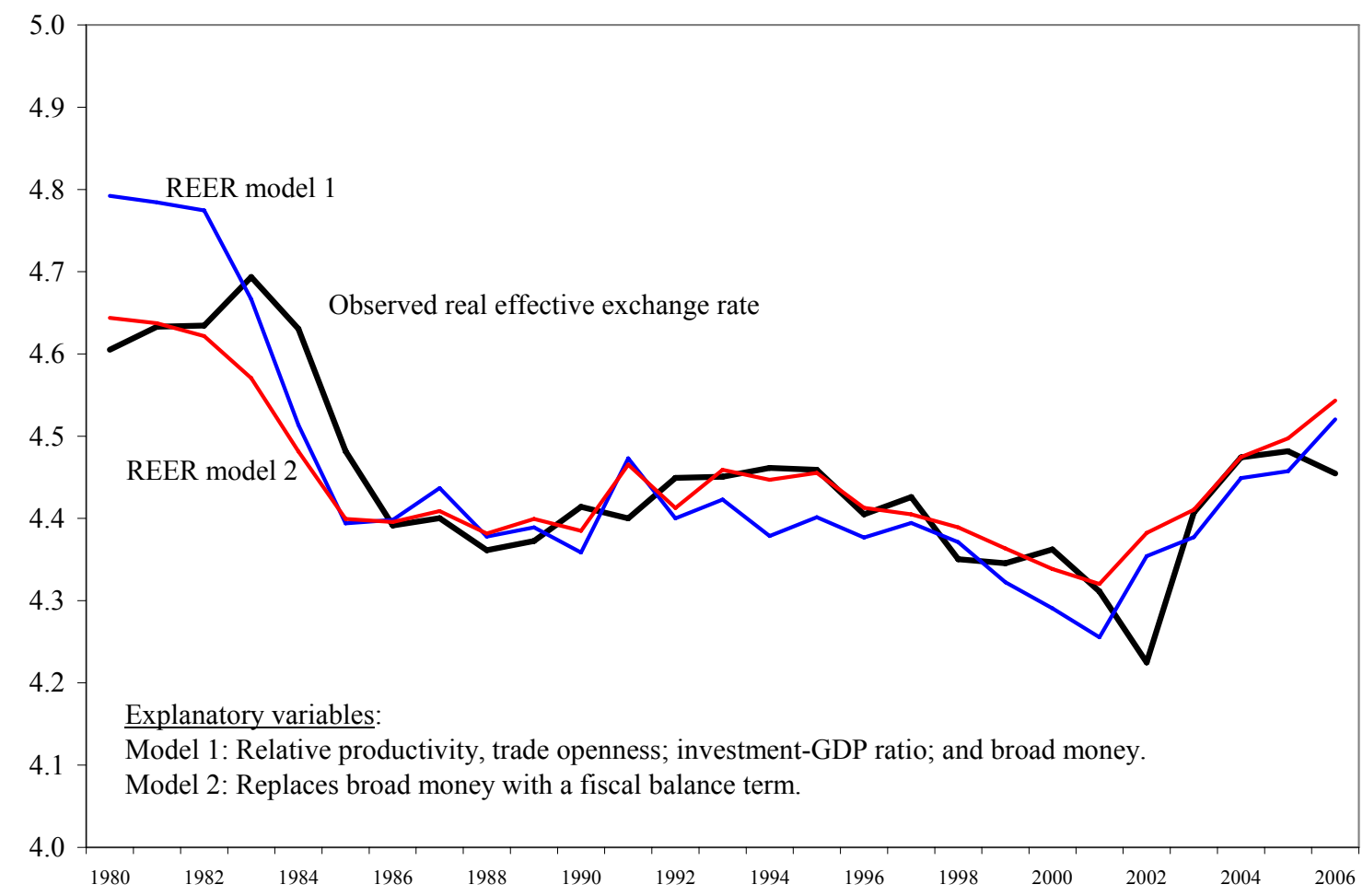

Source: IMF staff estimates.

\footnotetext{
${ }^{8}$ The model, documented in "What Do We Know About Namibia's Competitiveness?" WP/07/191, is based on data for 1980-2006.

${ }^{9}$ Under the CMA, Namibia, Lesotho, and Swaziland peg their currencies to the South Africa rand, which is also legal tender in their territories. The CMA provides for free capital mobility. Separate central banks set interest rates and hold official reserves, which for Namibia, Lesotho, and Swaziland must equal or exceed domestic currency issue.
} 
15. Discussions on CMA issues focused on appropriate monetary policies. While Namibia's policy interest rate decisions have matched those of South Africa since mid-2004, the authorities saw macroeconomic conditions as diverging, with more evidence in Namibia of slowing domestic demand and inflation. Accordingly, the need for continuing to align Namibia's policies with South Africa's was being carefully reviewed (foreshadowing the decision not to match South Africa's 50-basis-point repo rate increase early in December). Staff noted the need to monitor closely the impact on capital outflows and official reserves.

\section{What Further Financial Sector Reforms are Needed? ${ }^{10}$}

\section{Background}

16. The financial sector is strong and increasingly well regulated. However, more effective intermediation of ample domestic savings to boost domestic investment and growth would be welcome.

- $\quad$ The banking system is very profitable, well-capitalized, with few nonperforming loans (Figure 8); private sector credit is relatively high by international standards, amounting to 58 percent of GDP in 2006. As the 2006 FSAP found, bank outreach to poorer households and small and medium-sized enterprises could be better. Banks are now extending their outreach through a range of innovative savings and credit products.

- $\quad$ Namibia's well-developed life insurance and pension fund sector is required to invest 35 percent of portfolios domestically; the industry typically invests much of the rest abroad, citing a lack of domestic investment opportunities. The capitalization of local companies on the domestic stock market is just 6 percent of GDP (only seven local companies are listed); public debt is low; and volume on the secondary corporate debt market is low. Pension savings are one factor behind Namibia's capital outflows; most middle-income countries have capital inflows.

\footnotetext{
${ }^{10}$ See also the selected issues paper, "Namibia's Domestic Investment Requirements: Proposed Legislation, Issues, and Options."
} 
Figure 8. Namibia: Financial Sector Developments

With the decline in government debt, interest rates are trending lower than in South Africa.

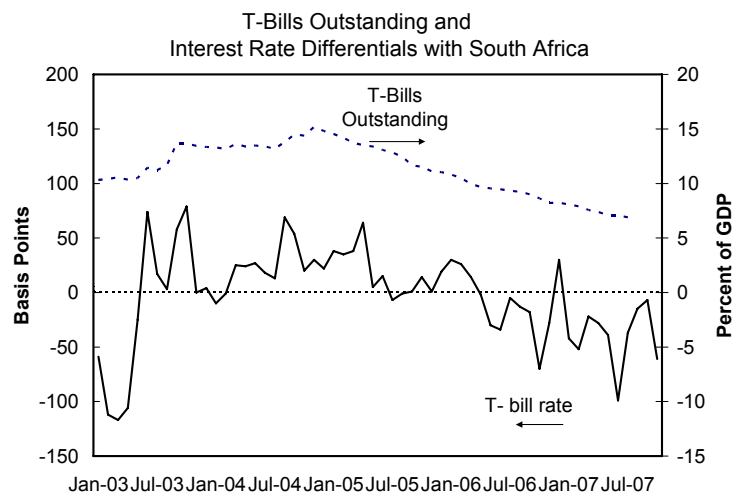

... banks are profitable, ...

Return on Assets and Equity

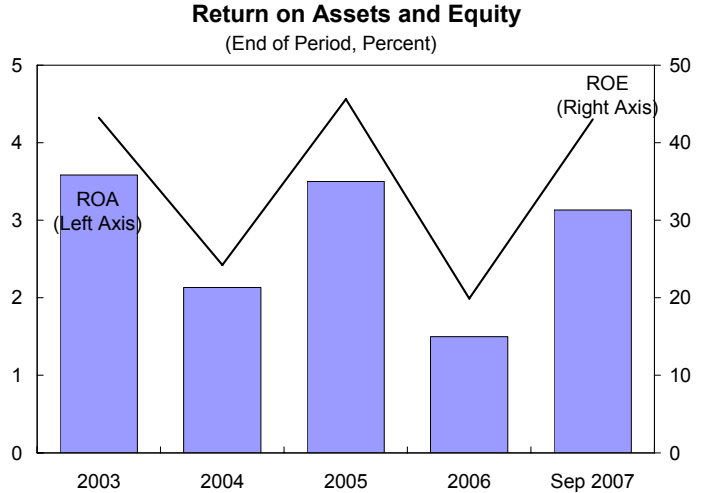

Government pensions are heavily vested in South Africa and in equities.

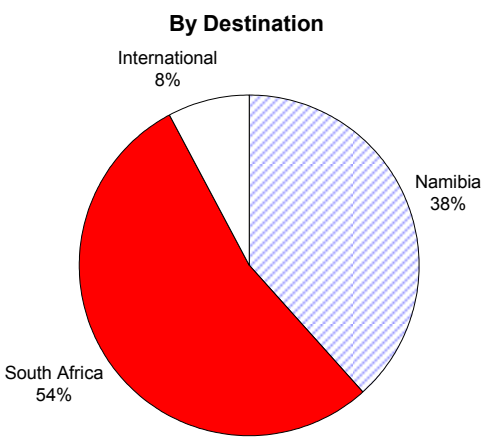

(March 2005)
Bank lending margins are at healthy and relatively high levels, ...

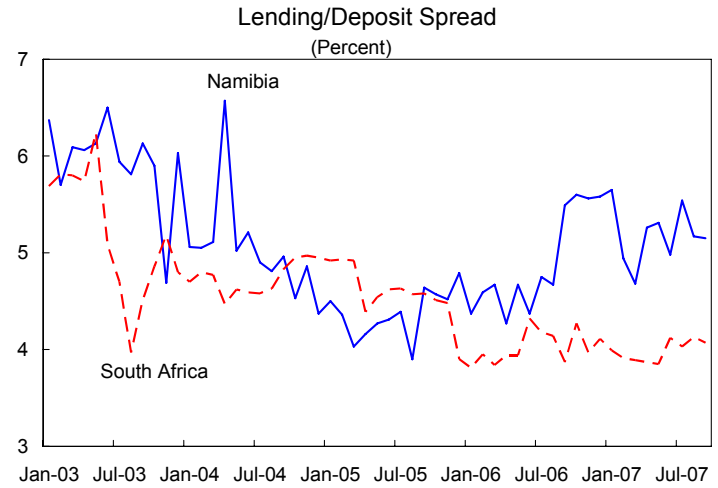

... and prudential ratios are in good shape.

Capital Adequacy and NPLs

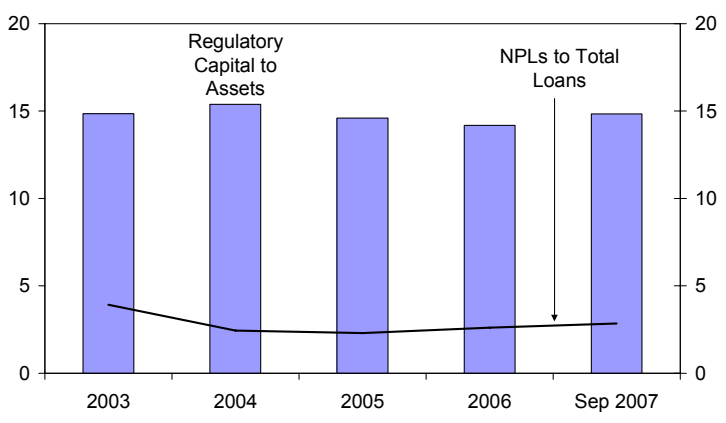

Namibia's stock index has tracked South Africa's, but local companies have underperformed.

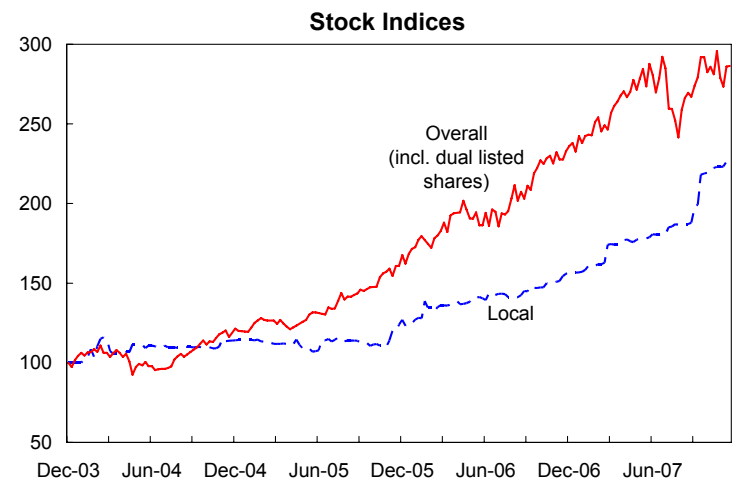

Equities $=66 \%$, Fixed Income $=21 \%$, Cash $=12 \%$

Source: Namibian authorities. 
Savings and Investment, 1990-2006

(Percent of GDP)

\begin{tabular}{lccc}
\hline & Savings & Investment & $\begin{array}{c}\text { Capital } \\
\text { and } \\
\text { Financial } \\
\text { Inflows }\end{array}$ \\
\hline 1990-2006 & 19.9 & 24.8 & 4.7 \\
Middle-income countries & 27.4 & 22.9 & -4.5 \\
Namibia & & & \\
2004-2006 & 21.9 & 24.8 & 3.4 \\
Middle-income countries & 36.5 & 26.6 & -9.9 \\
\hline Namibia & &
\end{tabular}

Sources: Namibian authorities; and IMF staff projections.

- $\quad$ Tighter regulation of pension and insurance fund domestic investments is being considered. Specifically, the funds would no longer be able to meet the current 35 percent domestic investment requirement with holdings in foreign companies dual-listed on the Namibia stock exchange, and would have to dedicate some of their portfolios to investments in domestic unlisted companies.

- $\quad$ Financial sector supervision is also being reinforced, as recommended in the 2006 FSAP. ${ }^{11}$ An overhaul of NAMFISA, which supervises nonbanks, was initiated in 2006 after a new CEO was appointed. Staffing and training have been increased in both NAMFISA and the Bank of Namibia, the banking regulator; risk-based supervision has been initiated; both institutions have stepped up on-site visits; NAMFISA has taken a medium-sized insurance company into curatorship; and a number of banking regulations have been issued. But collection and analysis of data from the nonbank financial sector is lagging; a full prudential picture of the sector is unlikely before mid-2008.

\section{Policy discussions}

17. The authorities emphasized the need for further outreach by the banking community and more domestic investments by pension and life insurance funds. A voluntary charter is being drafted under which banks will agree to meet social and economic benchmarks for personnel management and lending. The authorities noted that tighter domestic investment requirements were needed to encourage portfolio managers of pension and insurance companies to look beyond the "easy option" of investing in South Africa's deeper markets. Any changes are to be implemented cautiously, monitoring closely the impact on the industry.

\footnotetext{
${ }^{11}$ Anti-money-laundering policies were strengthened in 2007 with enactment of the Financial Intelligence Act and establishment of a financial intelligence center within the Bank of Namibia (BoN). Implementing regulations are being drafted, and training needs and the roles of the respective government agencies are being analyzed.
} 
18. Staff urged caution in tightening domestic investment requirements. International experience suggests that pension funds earn higher returns when investment is not restricted. Moreover, a domestic development mandate leaves funds vulnerable to pressures to finance nonviable projects. Requirements to invest in unlisted securities pose a particular risk, because unlisted companies disclose less about their finances. Staff noted that the required repatriation of funds, which could amount to 10 percent of GDP or more, could exceed the economy's ability to absorb it. There are also uncertainties about enforceability. Pension and insurance funds could probably side-step the regulations by investing in local banks, which would still be free to invest in South African bonds. This would result in no real increase in domestic financing while lowering returns through (a) a likely shift from equity to fixedincome returns favored by banks and (b) intermediation fees paid to banks.

19. The authorities discounted concerns about investment opportunities. They believe portfolio managers will find considerable unmet domestic demand for financing. The authorities concurred, however, on the merits of broadening the range of investment options through, e.g., bond issues by solid public agencies (following the precedent of NamPower) and indicated they would look into international experience with securitization of mortgages (which make up 40 percent of banks' loan portfolios), and factoring and leasing.

\section{How to Reduce Unemployment?}

\section{Background}

\section{Unemployment is a major problem:}

- Unemployment generally was 22 percent in 2004, not counting those not seeking work, and was 44 percent for urban 20- to 24-year olds.

- Job creation is needed. The mining sector provides few jobs; employment in agriculture is likely to continue to decline; and fiscal considerations preclude further expansion of public sector employment. Private nonfarm, nonmining employment (currently 192,000) would need to rise by almost 60 percent to absorb the 108,000 unemployed.

Namibian Labor Force Trends, 1997-2004

\begin{tabular}{lccccc}
\hline & $\begin{array}{c}\text { Labor Force } \\
\text { Status } \\
(\mathbf{6} \mathbf{0 0 0 s}, \mathbf{2 0 0 4 )}\end{array}$ & $\begin{array}{c}\text { Value-added } \\
\text { per Employee } \\
\text { (US\$, 2004) }\end{array}$ & $\begin{array}{c}\text { Labor } \\
\text { Growth } \\
(\mathbf{1 9 9 7 - 2 0 0 4 )}\end{array}$ & $\begin{array}{c}\text { Output } \\
\text { Growth } \\
(\mathbf{1 9 9 7 - 2 0 0 4 )}\end{array}$ & $\begin{array}{c}\text { Labor } \\
\text { Productivity } \\
\text { Growth } \\
\mathbf{( 1 9 9 7 - 2 0 0 4 )}\end{array}$ \\
\hline Total employment & 385 & $\$ 13,300$ & -0.6 & 4.0 & 4.8 \\
Mining & 8 & $\$ 71,500$ & 2.0 & 5.7 & 3.6 \\
Agriculture & 103 & $\$ 2,800$ & -5.0 & 1.4 & 6.7 \\
Other employment & 275 & $\$ 15,500$ & 1.5 & 4.5 & 2.9 \\
Public sector & 83 & $\ldots$ & 1.2 & $\ldots$ & $\ldots$ \\
Private sector & 192 & $\ldots$ & 1.6 & $\ldots$ & $\ldots$ \\
Unemployment & 108 & $\ldots$ & 1.5 & $\ldots$ & $\ldots$ \\
Labor force & 493 & $\ldots$ & -0.1 & $\ldots$ & $\ldots$ \\
\hline
\end{tabular}

Source: Namibian Labor Force Surveys.

${ }^{1}$ Narrow definition, excluding individuals not looking for work. 


\section{A superior business climate would compensate for difficult geographic conditions:}

- Namibia's economic geography complicates diversification. The domestic market is limited, and the population is small and widely dispersed. Limited water resources and distances from advanced economies are a further challenge.

- Infrastructure is fairly well-developed, with business access to rail, port, and air facilities viewed as superior to the average for lower-middle-income countries.

- Economic governance is ranked in most surveys below Botswana and South Africa, but is above average for a lower-middle-income country. The decline in government effectiveness and control of corruption indicators over the past decade, while not statistically significant, is nevertheless indicative. ${ }^{12}$ However, an Anti-Corruption Commission became effective in 2006.

22. Skills gaps and inflexible labor markets are obstacles to job growth:

- $\quad$ Education and skills: At independence, Namibia inherited a poor education system. The probability of employment is little higher for students with education up to grade 10 than for the uneducated, but an education and skills reform program has been launched with support from development partners.

International Governance Indicators, 2006

(Percentile ranking, $100=$ strongest)

\begin{tabular}{lccc}
\hline & $\begin{array}{c}\text { Government } \\
\text { Effectiveness }\end{array}$ & $\begin{array}{c}\text { Regulatory } \\
\text { Quality }\end{array}$ & $\begin{array}{c}\text { Control of } \\
\text { Corruption }\end{array}$ \\
\hline Sub-Saharan Africa & 27.2 & 27.4 & 30.3 \\
Lower-middle-income countries & 37.8 & 36.6 & 37.7 \\
Namibia & 59.2 & 57.1 & 61.2 \\
Upper-middle-income countries & 61.5 & 63.0 & 60.9 \\
Botswana & 73.9 & 75.6 & 78.2 \\
South Africa & 76.8 & 70.2 & 70.9 \\
Namibia (1996) & 73.0 & 46.8 & 78.2 \\
\hline
\end{tabular}

Source: World Bank.

\footnotetext{
${ }^{12}$ The differences between Namibia and other lower-middle-income countries is significant at the 90 percent level, as are differences with Botswana and South Africa for government effectiveness, and with Botswana for control of corruption.
} 
- $\quad$ Labor market functioning: Workforce management is complicated by lengthy and contentious challenges to worker dismissals in district labor courts. The pending Labor Law would increase annual leave eligibility to 24 days (plus 5 days' compassionate leave), substantially above many middle-income country peers. ${ }^{13}$

23. Staff recommended continuing liberalization of the trade regime, including through broader free trade arrangements. A wider free trade area across SADC would increase market access for Namibia but is unlikely to be achieved by the 2008 target date because non-SACU members are progressing slowly. Namibia signed an interim Economic Partnership Agreement (EPA) with the European Union in mid-December. This will preserve Namibia's access to the EU market and lower tariffs over time.

\section{Policy discussions}

24. The authorities agreed that reducing unemployment is a top priority, and will depend on building labor productivity and skills. Accordingly, a new Productivity Center is being launched in the Ministry of Labor, and the planned opening in 2009 of a National Institute of Public Administration and Management should make the civil service more effective. Meanwhile, staff urged that the work permit process be streamlined for hard-to-fill occupations. Reforms are being discussed, but the authorities underlined the need for employers to do more to recruit Namibian workers.

25. The authorities recognized the arguments for more flexible labor markets but pointed to the importance of improving working conditions since independence. The authorities envisage considerable improvements in the labor market under the pending Labor Law, which will promote conciliation and arbitration as an alternative to legal challenges to worker dismissals. They also considered that labor relations would benefit from industry-level voluntary charters for the empowerment of the previously disadvantaged. Staff noted that non-wage labor costs might rise as a result of the expanded leave provisions in the new law and recommended that employers be permitted to establish lower leave standards for new hires, with subsequent increases based on job seniority.

\section{Staff Appraisal}

26. Achievements: Namibia's economic position is strong. Economic growth is robust, and inflation has declined since peaking in mid-2007. National savings have reduced public indebtedness, built official reserves to a healthy level, and financed new private investments at home and abroad. The banking system is profitable and well-capitalized.

27. Vulnerabilities: Volatility in the mining sector and declines in SACU receipts remain risks. Political support for economic reforms is strong but would be reinforced by success in tackling unemployment and income inequality.

\footnotetext{
${ }^{13}$ Statutory annual leave is 15 days in Botswana, Chile, and South Africa; 8-16 days in Malaysia (depending on service); and 6 days in Thailand.
} 
28. Currency valuation: Namibia's large current account surplus partly reflects a tight fiscal position that is projected to ease over the medium term. While there is considerable uncertainty about the cause of the recent increase in private saving, there is little evidence of any significant currency undervaluation. Consistent with the authorities' commitment to the CMA, interest rate differentials with South Africa should be limited to levels that do not destabilize capital flows or official reserves.

29. Fiscal policy: Using a good part of the recent surge in SACU transfers and mineral revenues to reduce public debt was appropriate. The emerging fiscal space and reprioritization of expenditures provide scope for modest increases for infrastructure and other programs.

30. Expenditure management: To help prioritize and monitor expenditures, adoption of a program classification for budget execution and reporting should be a priority. Because the public wage bill is high, new hires and remuneration should be strictly limited, but adequate salaries for critical staff should be ensured. To reduce risks to the budget from SOEs, the SOE Governance Act needs to be implemented.

31. Revenue policies: Tax administration should be strengthened in case SACU receipts fall. Domestic revenue reforms have been hampered by recruitment and retention issues and poor taxpayer compliance; efforts to strengthen the strategic and operational functions of the Inland Revenue Department should be redoubled.

32. Financial policies: Financial sector management is being enhanced consistent with the recommendations of the 2006 FSAP. The authorities should continue to explore the scope for fostering competition in the banking sector. Caution is needed in modifying domestic investment requirements for pension and insurance companies - especially minimum investments in unlisted securities - to avoid raising industry risk and deteriorating returns.

33. Structural reforms: Fostering employment growth in the nonmining economy to reduce unemployment is a central challenge. It will require forceful efforts to build skills and labor productivity, especially through greater labor market flexibility. The business climate also needs to be improved. Given Namibia's daunting economic geography, it must build on its comparatively strong economic institutions and tackle bureaucratic obstacles. Further liberalization of the trade regime remains a priority.

34. It is recommended that the next Article IV consultation take place on the standard 12-month cycle. 
Table 1. Namibia: Selected Financial and Economic Indicators, 2003-12

\begin{tabular}{|c|c|c|c|c|c|c|c|c|c|c|}
\hline & 2003 & 2004 & 2005 & 2006 & 2007 & 2008 & 2009 & 2010 & 2011 & 2012 \\
\hline & & & & \multicolumn{7}{|c|}{ Projections } \\
\hline & \multicolumn{10}{|c|}{ (Annual percent change, unless otherwise noted) } \\
\hline \multicolumn{11}{|l|}{ National income and prices } \\
\hline GDP at constant 1995 prices & 3.5 & 6.6 & 4.8 & 4.1 & 4.4 & 4.8 & 4.5 & 4.8 & 4.7 & 4.8 \\
\hline GDP deflator & -0.6 & 1.1 & 3.8 & 13.7 & 6.5 & 6.0 & 5.3 & 5.2 & 5.2 & 5.6 \\
\hline GDP at current market prices ( $\mathrm{N} \$$ millions) & 33,842 & 36,496 & 39,711 & 46,971 & 52,208 & 57,987 & 63,777 & 70,339 & 77,513 & 85,828 \\
\hline GDP per capita (US\$) & 2,253 & 2,816 & 3,073 & 3,389 & 3,562 & 3,861 & 4,077 & 4,319 & 4,572 & 4,863 \\
\hline Consumer price index (period average) & 7.2 & 4.1 & 2.3 & 5.1 & 6.7 & 6.1 & 5.5 & 5.5 & 5.5 & 5.5 \\
\hline Consumer price index (end of period) & 2.6 & 4.3 & 3.5 & 6.0 & 6.7 & 5.7 & 5.5 & 5.5 & 5.5 & 5.5 \\
\hline \multicolumn{11}{|l|}{ External sector } \\
\hline Exports (US\$) & 16.6 & 45.8 & 13.3 & 28.3 & 13.8 & 5.4 & -0.6 & 1.1 & 3.4 & 4.0 \\
\hline Imports (US\$) & 33.7 & 23.1 & 10.7 & 9.7 & 13.2 & 16.8 & 5.8 & 6.1 & 6.0 & 8.2 \\
\hline Export volume & 6.3 & 27.4 & -1.2 & 17.6 & -9.3 & 8.4 & 3.0 & 3.2 & 3.0 & 1.8 \\
\hline Import volume & 5.2 & 6.6 & 5.2 & 5.0 & 4.4 & 12.8 & 2.5 & 2.8 & 2.7 & 4.8 \\
\hline Terms of trade & 0.2 & 8.5 & 4.8 & 11.1 & 20.5 & -6.1 & -6.4 & -5.1 & -2.7 & -1.0 \\
\hline Real effective exchange rate (period average) ${ }^{2}$ & 20.0 & 7.0 & 0.7 & -2.7 & -6.2 & $\ldots$ & $\ldots$ & $\ldots$ & $\ldots$ & $\ldots$ \\
\hline \multicolumn{11}{|l|}{ Money and credit } \\
\hline Credit to the private sector & 12.4 & 19.4 & 20.1 & 14.7 & 11.2 & 11.1 & 12.0 & 12.3 & 12.2 & 12.7 \\
\hline Broad money & 9.6 & 16.2 & 9.7 & 29.8 & 18.8 & 14.0 & 14.2 & 14.7 & 14.8 & 14.8 \\
\hline & \multicolumn{10}{|c|}{ (Percent of GDP, unless otherwise noted) } \\
\hline \multicolumn{11}{|l|}{ Investment and savings } \\
\hline Gross investment & 29.8 & 26.1 & 26.1 & 27.5 & 28.2 & 29.8 & 31.2 & 32.0 & 32.3 & 32.1 \\
\hline Public & 7.0 & 7.3 & 6.9 & 7.0 & 7.7 & 9.3 & 10.7 & 11.0 & 10.3 & 10.1 \\
\hline Private & 22.8 & 18.8 & 19.2 & 20.5 & 20.5 & 20.5 & 20.5 & 21.0 & 22.0 & 22.0 \\
\hline Gross domestic savings & 22.6 & 22.1 & 22.6 & 30.3 & 31.3 & 27.9 & 27.2 & 26.6 & 26.5 & 24.9 \\
\hline Gross national savings & 36.5 & 34.3 & 31.6 & 43.4 & 46.7 & 42.4 & 40.9 & 39.7 & 39.3 & 37.5 \\
\hline Public & -0.7 & 1.0 & 3.2 & 7.8 & 9.4 & 8.3 & 7.4 & 7.0 & 7.0 & 6.7 \\
\hline Private & 37.2 & 33.3 & 28.4 & 35.7 & 37.3 & 34.1 & 33.5 & 32.7 & 32.3 & 30.8 \\
\hline \multicolumn{11}{|l|}{ Central government finance ${ }^{1}$} \\
\hline Revenue and grants & 28.3 & 30.5 & 31.5 & 35.0 & 36.3 & 34.7 & 33.9 & 33.6 & 33.6 & 33.3 \\
\hline Of which: SACU receipts & 8.8 & 11.3 & 9.4 & 13.9 & 14.2 & 12.8 & 12.1 & 11.8 & 11.6 & 11.4 \\
\hline Expenditure and net lending & 35.7 & 33.9 & 32.0 & 31.6 & 33.7 & 34.6 & 35.2 & 35.1 & 34.6 & 34.6 \\
\hline Of which: personnel expenditure & 14.8 & 14.6 & 14.2 & 12.9 & 13.0 & 13.0 & 13.0 & 13.0 & 13.0 & 13.0 \\
\hline capital expenditure and net lending & 5.6 & 5.2 & 4.0 & 5.7 & 6.9 & 7.8 & 8.5 & 8.5 & 8.0 & 8.0 \\
\hline Primary balance (deficit $=-$ ) & -5.0 & -0.7 & 2.3 & 6.0 & 5.2 & 2.2 & 0.8 & 0.5 & 1.1 & 0.8 \\
\hline Overall government deficit including grants & -7.5 & -3.4 & -0.5 & 3.4 & 2.6 & 0.1 & -1.3 & -1.5 & -1.0 & -1.3 \\
\hline Public and publicly guaranteed debt outstanding/GDP & 39.5 & 40.2 & 38.6 & 36.4 & 30.6 & 30.0 & 30.6 & 31.2 & 31.1 & 30.9 \\
\hline Public debt outstanding/GDP & 29.6 & 33.7 & 30.2 & 28.2 & 22.8 & 22.5 & 23.5 & 24.5 & 24.7 & 25.0 \\
\hline \multicolumn{11}{|l|}{ External sector } \\
\hline \multicolumn{11}{|l|}{ Current account balance } \\
\hline Including official transfers & 6.7 & 8.2 & 5.5 & 15.9 & 18.5 & 12.6 & 9.7 & 7.7 & 6.9 & 5.4 \\
\hline Excluding official transfers & -3.1 & -3.2 & -4.9 & 2.6 & 3.4 & -1.3 & -3.4 & -4.9 & -5.4 & -6.6 \\
\hline \multicolumn{11}{|l|}{ Gross official reserves } \\
\hline US\$ millions & 318.9 & 352.7 & 315.9 & 512.7 & 791.1 & 900.2 & 992.7 & 1072.6 & 1147.0 & 1225.0 \\
\hline Months of imports of goods and services & 1.9 & 1.7 & 1.4 & 2.1 & 2.8 & 2.7 & 2.8 & 2.9 & 2.9 & 2.9 \\
\hline External debt/GDP (percent) & 36.2 & 36.4 & 29.6 & 30.3 & 30.0 & 30.8 & 30.5 & 29.8 & 28.6 & 27.7 \\
\hline Exchange rate ( $\mathrm{N} \$ / \mathrm{US} \$$, end of period) & 6.6 & 5.6 & 6.3 & 7.0 & $\ldots$ & $\ldots$ & $\ldots$ & $\ldots$ & $\ldots$ & $\ldots$ \\
\hline Exchange rate $(\mathrm{N} \$ / \mathrm{US} \$$, period average $)$ & 7.6 & 6.4 & 6.4 & 6.8 & $\ldots$ & $\ldots$ & $\ldots$ & $\ldots$ & $\ldots$ & $\ldots$ \\
\hline
\end{tabular}

Sources: Namibian authorities; and IMF staff estimates and projections.

${ }^{1}$ Figures are for the fiscal year, which begins April 1.

${ }^{2}$ First 9 months of 2007 compared to a year earlier. 
Table 2. Namibia: Balance of Payments, 2003-12

(US\$ millions)

\begin{tabular}{|c|c|c|c|c|c|c|c|c|c|c|}
\hline & 2003 & 2004 & 2005 & 2006 & 2007 & 2008 & 2009 & 2010 & 2011 & $2012^{1}$ \\
\hline & & & & \multicolumn{7}{|c|}{ Projections } \\
\hline Current account & 299.9 & 461.7 & 344.4 & 1106.1 & 1357.2 & 1011.8 & 826.0 & 704.2 & 677.6 & 567.0 \\
\hline Goods & -460.2 & -283.6 & -265.3 & 94.8 & 121.3 & -203.0 & -415.7 & -599.1 & -717.9 & -912.7 \\
\hline Exports, f.o.b. & 1250.9 & 1823.4 & 2066.7 & 2652.3 & 3017.5 & 3180.2 & 3162.1 & 3196.4 & 3304.3 & 3437.7 \\
\hline Of which: diamonds & 510.9 & 824.5 & 848.3 & 1083.8 & 1153.6 & 1286.5 & 1305.6 & 1385.0 & 1468.6 & 1557.4 \\
\hline other minerals & 182.6 & 227.5 & 275.0 & 474.7 & 764.5 & 749.4 & 679.5 & 586.7 & 553.8 & 534.1 \\
\hline fish & 229.5 & 178.7 & 155.9 & 204.8 & 231.0 & 217.1 & 202.3 & 197.0 & 195.5 & 196.0 \\
\hline Imports, f.o.b. (excluding duty) & -1711.1 & -2107.0 & -2331.9 & -2557.5 & -2896.2 & -3383.2 & -3577.8 & -3795.5 & -4022.1 & -4350.5 \\
\hline Services & 138.6 & 54.9 & 43.1 & 97.2 & 107.3 & 48.2 & 72.2 & 104.7 & 142.9 & 163.3 \\
\hline Transportation & -6.6 & -109.9 & -107.8 & -48.5 & -90.4 & -127.0 & -135.0 & -141.5 & -147.7 & -162.6 \\
\hline Travel & 230.0 & 281.4 & 239.7 & 265.3 & 340.1 & 356.9 & 399.6 & 448.1 & 502.2 & 556.0 \\
\hline Other services & -84.7 & -116.6 & -88.8 & -119.8 & -142.4 & -181.6 & -192.3 & -201.9 & -211.6 & -230.1 \\
\hline Income & 163.2 & 23.1 & -103.1 & -35.8 & 0.4 & 25.4 & 31.6 & 24.3 & 27.4 & 37.4 \\
\hline Compensation of employees & -4.1 & -4.2 & -3.6 & -5.9 & -3.3 & -6.0 & -6.0 & -6.0 & -6.0 & -6.1 \\
\hline Investment income & 167.3 & 27.3 & -99.5 & -29.9 & 3.7 & 31.4 & 37.5 & 30.3 & 33.5 & 43.4 \\
\hline Current transfers & 458.3 & 667.3 & 669.7 & 949.9 & 1128.2 & 1141.1 & 1137.9 & 1174.2 & 1225.1 & 1279.0 \\
\hline Of which: SACU receipts ${ }^{2}$ & 386.8 & 606.8 & 650.1 & 893.9 & 1041.6 & 1054.4 & 1051.2 & 1087.6 & 1138.4 & 1192.4 \\
\hline Capital and financial account & -281.9 & -604.7 & -451.9 & -1236.8 & -1357.2 & -1011.8 & -826.0 & -704.2 & -677.6 & -567.0 \\
\hline Capital account & 67.3 & 77.2 & 79.4 & 84.7 & 82.1 & 68.3 & 64.6 & 57.9 & 63.6 & 62.0 \\
\hline Financial account & -349.2 & -681.9 & -531.3 & -1321.5 & -1439.3 & -1080.0 & -890.6 & -762.1 & -741.2 & -629.0 \\
\hline (Excluding reserve assets) & -365.4 & -648.5 & -568.8 & -1181.2 & -1110.9 & -970.9 & -798.1 & -682.1 & -666.8 & -550.9 \\
\hline Direct investment & 159.1 & 248.4 & 360.4 & 339.1 & 736.4 & 526.5 & 509.4 & 544.4 & 581.2 & 623.5 \\
\hline Portfolio investment & -633.5 & -842.6 & -1043.7 & -1112.4 & -1681.5 & -1507.1 & -1357.0 & -1222.3 & -1159.7 & -1101.9 \\
\hline Other investment & 108.9 & -54.3 & 114.4 & -407.9 & -165.7 & 9.7 & 49.5 & -4.2 & -88.3 & -72.5 \\
\hline Reserve assets (net) & 16.2 & -33.4 & 37.5 & -140.3 & -328.4 & -109.1 & -92.4 & -79.9 & -74.3 & -78.1 \\
\hline Net errors and omissions & -18.0 & 143.0 & 107.5 & 130.7 & 0.0 & 0.0 & 0.0 & 0.0 & 0.0 & 0.0 \\
\hline \multicolumn{11}{|l|}{ Memorandum items: } \\
\hline Trade balance/GDP & -10.3 & -5.0 & -4.3 & 1.4 & 1.6 & -2.5 & -4.9 & -6.6 & -7.4 & -8.7 \\
\hline \multicolumn{11}{|l|}{ Current account/GDP } \\
\hline Including transfers & 6.7 & 8.2 & 5.5 & 15.9 & 18.5 & 12.6 & 9.7 & 7.7 & 6.9 & 5.4 \\
\hline Excluding transfers & -3.1 & -3.2 & -4.9 & 2.6 & 3.4 & -1.3 & -3.4 & -4.9 & -5.4 & -6.6 \\
\hline Non-mineral, non-SACU Current Account/GDP & -17.4 & -21.2 & -22.9 & -19.4 & -21.8 & -25.9 & -25.8 & -25.8 & -25.4 & -26.0 \\
\hline Exports of GNFS & 1662.4 & 2297.5 & 2477.4 & 3181.8 & 3633.7 & 3853.5 & 3895.4 & 3995.8 & 4176.4 & 4389.8 \\
\hline Exports/GDP (percent) & 37.2 & 40.6 & 39.7 & 45.8 & 49.4 & 47.9 & 45.5 & 43.7 & 42.8 & 41.9 \\
\hline Imports of GNFS & 1984.0 & 2526.2 & 2699.6 & 2989.7 & 3405.1 & 4008.2 & 4238.9 & 4490.1 & 4751.3 & 5139.2 \\
\hline Imports/GDP (percent) & 44.3 & 44.6 & 43.3 & 43.1 & 46.3 & 49.9 & 49.5 & 49.1 & 48.7 & 49.1 \\
\hline Gross International reserves (end of period) ${ }^{3}$ & 318.9 & 352.7 & 315.9 & 512.7 & 791.1 & 900.2 & 992.7 & 1072.6 & 1147.0 & 1225.0 \\
\hline Months of imports of goods and services & 1.9 & 1.7 & 1.4 & 2.1 & 2.8 & 2.7 & 2.8 & 2.9 & 2.9 & 2.9 \\
\hline Ratio of reserves/short-term debt & 0.5 & 0.5 & 0.5 & 0.6 & 0.8 & 0.8 & 0.8 & 0.8 & 0.9 & 0.9 \\
\hline Short-term debt (US\$ millions) & 594.9 & 685.3 & 699.8 & 862.7 & 960.0 & 1188.7 & 1277.1 & 1313.3 & 1314.3 & 1316.3 \\
\hline External debt/GDP (percent) & 36.2 & 36.4 & 29.6 & 30.3 & 30.0 & 30.8 & 30.5 & 29.8 & 28.6 & 27.7 \\
\hline External debt (US\$ millions) from IIP & 1618.1 & 2060.1 & 1848.4 & 2101.1 & 2205.4 & 2475.1 & 2614.6 & 2720.4 & 2792.1 & 2894.6 \\
\hline Exchange rate (N\$/US\$, end of period) & 6.6 & 5.6 & 6.3 & 7.0 & $\ldots$ & $\ldots$ & $\ldots$ & $\ldots$ & $\ldots$ & $\ldots$ \\
\hline Exchange rate (N\$/US\$, period average) & 7.6 & 6.4 & 6.4 & 6.8 & & $\ldots$ & $\ldots$ & $\ldots$ & $\cdots$ & \\
\hline GDP at market prices (US\$ millions) & 4473.7 & 5658.4 & 6241.6 & 6941.0 & 7355.7 & 8038.8 & 8559.0 & 9143.4 & 9758.8 & 10466.7 \\
\hline
\end{tabular}

Sources: Namibian authorities; and IMF staff estimates and projections.

${ }^{1}$ Namibia will become a net exporter of electricity in 2012, when electricity production from the Kudu gas project is expected to be fully operational.

${ }^{2}$ Southern African Customs Union.

${ }^{3}$ Gross foreign assets of the Bank of Namibia, converted to U.S. dollars. 
Table 3. Namibia: Central Government Operations, 2005/06-2012/13

(N\$ millions)

\begin{tabular}{|c|c|c|c|c|c|c|c|c|c|c|}
\hline & \multirow[t]{2}{*}{$\underline{2005 / 06}$} & \multicolumn{2}{|c|}{$2006 / 07$} & \multicolumn{2}{|c|}{$2007 / 08$} & \multirow[t]{2}{*}{$\underline{2008 / 09}$} & \multirow[t]{2}{*}{$2009 / 10$} & \multirow{2}{*}{$\frac{2010 / 11}{\text { Projections }}$} & \multirow[t]{2}{*}{$2011 / 12$} & \multirow[t]{2}{*}{$2012 / 13$} \\
\hline & & Budget & Est. & Budget & Proj. & & & & & \\
\hline Revenue and grants & $13,075.3$ & $15,459.8$ & $16,892.6$ & $18,134.3$ & $19,475.5$ & $20,632.0$ & $22,181.1$ & $24,215.8$ & $26,709.7$ & $29,208.8$ \\
\hline Revenue & $13,036.3$ & $15,387.8$ & $16,843.0$ & $17,930.2$ & $19,271.5$ & $20,513.1$ & $22,050.3$ & $24,071.5$ & $26,550.6$ & $29,033.4$ \\
\hline Tax revenue & $11,886.7$ & $14,422.6$ & $15,734.4$ & $16,909.5$ & $17,942.0$ & $19,074.2$ & $20,442.1$ & $22,299.9$ & $24,532.6$ & $26,808.2$ \\
\hline Personal income tax & $2,905.3$ & $3,286.0$ & $3,373.6$ & $2,983.0$ & $3,750.0$ & $4,160.4$ & $4,611.9$ & $5,085.4$ & $5,647.1$ & $6,226.8$ \\
\hline Corporate income tax & $1,573.1$ & $1,302.0$ & $2,161.3$ & $2,070.0$ & $2,328.0$ & $2,615.1$ & $2,682.1$ & $2,921.4$ & $3,221.3$ & $3,508.1$ \\
\hline Diamond mining & 199.3 & 45.0 & 359.9 & 250.0 & 330.0 & 356.6 & 327.1 & 360.7 & 397.7 & 438.5 \\
\hline Other mining & 0.9 & 7.0 & 350.7 & 350.0 & 440.0 & 534.9 & 490.6 & 504.9 & 556.8 & 613.9 \\
\hline Nonmining & $1,373.0$ & $1,250.0$ & $1,450.8$ & $1,470.0$ & $1,558.0$ & $1,723.6$ & $1,864.4$ & $2,055.8$ & $2,266.8$ & $2,455.6$ \\
\hline VAT and sales taxes & $3,108.1$ & $2,925.0$ & $3,001.6$ & $3,263.0$ & $3,700.0$ & $4,101.0$ & $4,579.2$ & $5,049.3$ & $5,647.1$ & $6,226.8$ \\
\hline International taxes (includes SACU receipts) & $3,891.9$ & $6,471.4$ & $6,697.9$ & $8,085.0$ & $7,624.5$ & $7,600.0$ & $7,911.0$ & $8,518.5$ & $9,217.2$ & $9,963.5$ \\
\hline Other & 408.2 & 438.2 & 500.0 & 508.5 & 539.5 & 597.7 & 657.8 & 725.4 & 799.8 & 881.9 \\
\hline Nontax revenue & $1,149.6$ & 965.2 & $1,108.6$ & $1,020.7$ & $1,329.5$ & $1,438.9$ & $1,608.2$ & $1,771.6$ & $2,018.0$ & $2,225.2$ \\
\hline Diamond royalties & 404.6 & 258.3 & 482.0 & 271.2 & 550.0 & 594.3 & 654.2 & 721.3 & 795.4 & 877.0 \\
\hline Administrative fees, including license revenues & 519.2 & 419.2 & 411.7 & 490.0 & 490.0 & 542.8 & 597.4 & 658.8 & 726.4 & 801.0 \\
\hline Other & 225.8 & 287.7 & 214.8 & 259.4 & 289.4 & 301.7 & 356.6 & 391.5 & 496.3 & 547.2 \\
\hline Grants (tied) & 39.0 & 72.0 & 49.6 & 204.0 & 204.0 & 118.9 & 130.8 & 144.3 & 159.1 & 175.4 \\
\hline Expenditures & $13,279.4$ & $15,383.1$ & $15,242.9$ & $18,040.4$ & $18,083.2$ & $20,550.6$ & $23,011.5$ & $25,326.0$ & $27,518.3$ & $30,367.7$ \\
\hline Current expenditure & $11,614.3$ & $12,499.0$ & $12,512.4$ & $14,052.9$ & $14,395.7$ & $15,927.6$ & $17,465.3$ & $19,210.4$ & $21,172.7$ & $23,370.7$ \\
\hline Personnel & $5,888.8$ & $6,144.9$ & $6,213.1$ & $6,725.0$ & $6,950.0$ & $7,726.5$ & $8,504.3$ & $9,377.2$ & $10,339.8$ & $11,401.2$ \\
\hline Goods and services & $2,017.6$ & $2,323.3$ & $2,289.4$ & $3,104.6$ & $3,000.0$ & $3,566.1$ & $3,925.0$ & $4,328.0$ & $4,772.2$ & $5,262.1$ \\
\hline Interest payments & $1,162.4$ & $1,312.7$ & $1,262.6$ & $1,156.2$ & $1,378.7$ & $1,237.5$ & $1,372.6$ & $1,465.8$ & $1,686.1$ & $1,883.8$ \\
\hline Domestic & $1,080.1$ & $1,215.3$ & $1,168.9$ & $1,037.2$ & $1,256.7$ & $1,107.1$ & $1,202.4$ & $1,285.9$ & $1,495.8$ & $1,674.0$ \\
\hline Foreign & 82.3 & 97.5 & 93.7 & 118.9 & 122.0 & 130.4 & 170.2 & 179.9 & 190.3 & 209.8 \\
\hline Subsidies and current transfers & $2,545.6$ & $2,718.2$ & $2,747.3$ & $3,067.0$ & $3,067.0$ & $3,397.5$ & $3,663.4$ & $4,039.4$ & $4,374.5$ & $4,823.6$ \\
\hline Other & 0.0 & 0.0 & 0.0 & 0.0 & 0.0 & 0.0 & 0.0 & 0.0 & 0.0 & 0.0 \\
\hline Capital expenditure & $1,489.9$ & $2,297.8$ & $2,097.2$ & $2,792.1$ & $2,492.1$ & $3,447.2$ & $4,252.1$ & $4,688.6$ & $4,772.2$ & $5,262.1$ \\
\hline Acquisition of capital assets & $1,383.9$ & $2,049.3$ & $\ldots$ & $2,450.3$ & $\ldots$ & $3,447.2$ & $4,252.1$ & $4,688.6$ & $4,772.2$ & $5,262.1$ \\
\hline Capital transfers & 106.0 & 248.4 & $\ldots$ & 341.8 & $\ldots$ & 0.0 & 0.0 & 0.0 & 0.0 & 0.0 \\
\hline Net lending & 175.1 & 586.4 & 633.2 & $1,195.5$ & $1,195.5$ & $1,175.7$ & $1,294.1$ & $1,426.9$ & $1,573.4$ & $1,734.9$ \\
\hline Overall balance ${ }^{1}$ & -204.1 & 76.6 & $1,649.7$ & 93.9 & $1,392.3$ & 81.4 & -830.3 & $-1,110.2$ & -808.7 & $-1,158.9$ \\
\hline Overall balance excluding extrabudgetary spending ${ }^{1}$ & -57.8 & 403.4 & $1,845.7$ & 376.1 & $1,561.6$ & 176.0 & -726.2 & -995.4 & -682.1 & $-1,019.4$ \\
\hline Primary balance & 958.3 & $1,389.4$ & $2,912.3$ & $1,250.0$ & $2,771.0$ & $1,318.9$ & 542.2 & 355.6 & 877.5 & 724.9 \\
\hline Statistical discrepancy & 9.0 & 0.0 & -66.3 & 0.0 & 0.0 & 0.0 & 0.0 & 0.0 & 0.0 & 0.0 \\
\hline Financing & 213.1 & -76.6 & $-1,716.0$ & -93.9 & $-1,392.3$ & -81.4 & 830.3 & $1,110.2$ & 808.7 & $1,158.9$ \\
\hline Domestic & 100.9 & $-1,052.8$ & $-2,561.5$ & -342.1 & $-1,527.6$ & -138.4 & 767.6 & $1,041.1$ & 732.4 & $1,074.9$ \\
\hline Central bank & -46.0 & $\ldots$ & $-2,799.5$ & $\ldots$ & 174.0 & -932.3 & -902.0 & -867.5 & -887.0 & -704.0 \\
\hline Commercial banks & 481.6 & $\ldots$ & 558.9 & $\ldots$ & -400.0 & -100.0 & -100.0 & -100.0 & -100.0 & -100.0 \\
\hline Nonbank & -334.8 & $\ldots$ & -320.9 & $\ldots$ & $-1,301.6$ & 893.9 & $1,769.6$ & $2,008.6$ & $1,719.4$ & $1,878.8$ \\
\hline External & 112.2 & 292.7 & 162.0 & 248.3 & 135.4 & 57.0 & 62.7 & 69.1 & 76.2 & 84.1 \\
\hline Disbursements & 146.2 & 326.7 & 196.0 & 282.3 & 169.4 & 94.6 & 104.1 & 114.8 & 126.6 & 139.6 \\
\hline Amortization & -34.0 & -34.0 & -34.0 & -34.0 & -34.0 & -37.6 & -41.4 & -45.7 & -50.3 & -55.5 \\
\hline Privatization & $\ldots$ & 683.5 & 683.5 & $\cdots$ & $\ldots$ & $\cdots$ & $\ldots$ & $\ldots$ & $\cdots$ & $\ldots$ \\
\hline \multicolumn{11}{|l|}{ Memorandum items: } \\
\hline Public and publicly guaranteed debt & $16,037.9$ & $\ldots$ & $17,405.6$ & $\ldots$ & $16,444.4$ & $17,837.8$ & $20,032.7$ & $22,509.2$ & $24,725.2$ & $27,129.2$ \\
\hline Public debt & $12,533.1$ & $\ldots$ & $13,638.0$ & $\ldots$ & $12,238.0$ & $13,356.4$ & $15,361.9$ & $17,647.4$ & $19,682.5$ & $21,919.7$ \\
\hline Domestic & $10,689.8$ & $\ldots$ & $10,927.8$ & $\ldots$ & $9,226.2$ & $10,020.1$ & $11,689.7$ & $13,598.3$ & $15,217.7$ & $16,996.6$ \\
\hline External & $1,843.3$ & $\ldots$ & $2,710.2$ & $\ldots$ & $3,011.8$ & $3,336.3$ & $3,672.2$ & $4,049.1$ & $4,464.8$ & 4,923.1 \\
\hline Publicly guaranteed debt & $3,504.8$ & $\ldots$ & $3,767.6$ & $\ldots$ & $4,206.4$ & $4,481.4$ & $4,670.8$ & $4,861.7$ & $5,042.7$ & $5,209.5$ \\
\hline GDP at current market prices ( $N \$$ millions) & 41,526 & 44,002 & 48,280 & 50,583 & 53,653 & 59,435 & 65,417 & 72,133 & 79,537 & 87,702 \\
\hline
\end{tabular}

Sources: Namibian authorities; and IMF staff estimates and projections.

1 "Overall balance" reflects externally financed project spending (except for roads) that is not channeled through the state account. "Overall balance excluding extrabudgetary spending" excludes such spending and thus corresponds directly with the authorities' concept. 
Table 3. Namibia: Central Government Operations, 2005/06-2012/13 (concluded)

(Percent of GDP)

\begin{tabular}{|c|c|c|c|c|c|c|c|c|c|c|}
\hline & \multirow[t]{2}{*}{$\underline{2005 / 06}$} & \multicolumn{2}{|c|}{$2006 / 07$} & \multicolumn{2}{|c|}{$2007 / 08$} & \multirow[t]{2}{*}{$2008 / 09$} & \multirow{2}{*}{$2009 / 10$} & $2010 / 11$ & \multirow{2}{*}{$\frac{2011 / 12}{S}$} & \multirow[t]{2}{*}{$2012 / 13$} \\
\hline & & Budget & Est. & Budget & Proj. & & & Projections & & \\
\hline Revenue and grants & 31.5 & 35.1 & 35.0 & 35.9 & 36.3 & 34.7 & 33.9 & 33.6 & 33.6 & 33.3 \\
\hline Revenue & 31.4 & 35.0 & 34.9 & 35.4 & 35.9 & 34.5 & 33.7 & 33.4 & 33.4 & 33.1 \\
\hline Tax revenue & 28.6 & 32.8 & 32.6 & 33.4 & 33.4 & 32.1 & 31.2 & 30.9 & 30.8 & 30.6 \\
\hline Personal income tax & 7.0 & 7.5 & 7.0 & 5.9 & 7.0 & 7.0 & 7.1 & 7.1 & 7.1 & 7.1 \\
\hline Corporate income tax & 3.8 & 3.0 & 4.5 & 4.1 & 4.3 & 4.4 & 4.1 & 4.1 & 4.1 & 4.0 \\
\hline Diamond mining & 0.5 & 0.1 & 0.7 & 0.5 & 0.6 & 0.6 & 0.5 & 0.5 & 0.5 & 0.5 \\
\hline Other mining & 0.0 & 0.0 & 0.7 & 0.7 & 0.8 & 0.9 & 0.8 & 0.7 & 0.7 & 0.7 \\
\hline Nonmining & 3.3 & 2.8 & 3.0 & 2.9 & 2.9 & 2.9 & 2.9 & 2.9 & 2.9 & 2.8 \\
\hline VAT and sales taxes & 7.5 & 6.6 & 6.2 & 6.5 & 6.9 & 6.9 & 7.0 & 7.0 & 7.1 & 7.1 \\
\hline International taxes (includes SACU receipts) & 9.4 & 14.7 & 13.9 & 16.0 & 14.2 & 12.8 & 12.1 & 11.8 & 11.6 & 11.4 \\
\hline Other & 1.0 & 1.0 & 1.0 & 1.0 & 1.0 & 1.0 & 1.0 & 1.0 & 1.0 & 1.0 \\
\hline Nontax revenue & 2.8 & 2.2 & 2.3 & 2.0 & 2.5 & 2.4 & 2.5 & 2.5 & 2.5 & 2.5 \\
\hline Diamond royalties & 1.0 & 0.6 & 1.0 & 0.5 & 1.0 & 1.0 & 1.0 & 1.0 & 1.0 & 1.0 \\
\hline Administrative fees, including license revenues & 1.3 & 1.0 & 0.9 & 1.0 & 0.9 & 0.9 & 0.9 & 0.9 & 0.9 & 0.9 \\
\hline Other & 0.5 & 0.7 & 0.4 & 0.5 & 0.5 & 0.5 & 0.5 & 0.5 & 0.6 & 0.6 \\
\hline Grants (tied) & 0.1 & 0.2 & 0.1 & 0.4 & 0.4 & 0.2 & 0.2 & 0.2 & 0.2 & 0.2 \\
\hline Expenditures & 32.0 & 35.0 & 31.6 & 35.7 & 33.7 & 34.6 & 35.2 & 35.1 & 34.6 & 34.6 \\
\hline Current expenditure & 28.0 & 28.4 & 25.9 & 27.8 & 26.8 & 26.8 & 26.7 & 26.6 & 26.6 & 26.6 \\
\hline Personnel & 14.2 & 14.0 & 12.9 & 13.3 & 13.0 & 13.0 & 13.0 & 13.0 & 13.0 & 13.0 \\
\hline Goods and services & 4.9 & 5.3 & 4.7 & 6.1 & 5.6 & 6.0 & 6.0 & 6.0 & 6.0 & 6.0 \\
\hline Interest payments & 2.8 & 3.0 & 2.6 & 2.3 & 2.6 & 2.1 & 2.1 & 2.0 & 2.1 & 2.1 \\
\hline Domestic & 2.6 & 2.8 & $\ldots$ & 2.1 & 2.3 & 1.9 & 1.8 & 1.8 & 1.9 & 1.9 \\
\hline Foreign & 0.2 & 0.2 & $\ldots$ & 0.2 & 0.2 & 0.2 & 0.3 & 0.2 & 0.2 & 0.2 \\
\hline Subsidies and current transfers & 6.1 & 6.2 & 5.7 & 6.1 & 5.7 & 5.7 & 5.6 & 5.6 & 5.5 & 5.5 \\
\hline Other & 0.0 & 0.0 & 0.0 & 0.0 & 0.0 & 0.0 & 0.0 & 0.0 & 0.0 & 0.0 \\
\hline Capital expenditure & 3.6 & 5.2 & 4.3 & 5.5 & 4.6 & 5.8 & 6.5 & 6.5 & 6.0 & 6.0 \\
\hline Acquisition of capital assets & 3.3 & 4.7 & $\ldots$ & 4.8 & $\ldots$ & 5.8 & 6.5 & 6.5 & 6.0 & 6.0 \\
\hline Capital transfers & 0.3 & 0.6 & $\ldots$ & 0.7 & $\ldots$ & 0.0 & 0.0 & 0.0 & 0.0 & 0.0 \\
\hline Net lending & 0.4 & 1.3 & 1.3 & 2.4 & 2.2 & 2.0 & 2.0 & 2.0 & 2.0 & 2.0 \\
\hline Overall balance $^{1}$ & -0.5 & 0.2 & 3.4 & 0.2 & 2.6 & 0.1 & -1.3 & -1.5 & -1.0 & -1.3 \\
\hline Overall balance excluding extrabudgetary spending ${ }^{1}$ & -0.1 & 0.9 & 3.8 & 0.7 & 2.9 & 0.3 & -1.1 & -1.4 & -0.9 & -1.2 \\
\hline Primary balance & 2.3 & 3.2 & 6.0 & 2.5 & 5.2 & 2.2 & 0.8 & 0.5 & 1.1 & 0.8 \\
\hline Statistical discrepancy & 0.0 & 0.0 & -0.1 & 0.0 & 0.0 & 0.0 & 0.0 & 0.0 & 0.0 & 0.0 \\
\hline Financing & 0.5 & -0.2 & -3.6 & -0.2 & -2.6 & -0.1 & 1.3 & 1.5 & 1.0 & 1.3 \\
\hline Domestic & 0.2 & -2.4 & -5.3 & -0.7 & -2.8 & -0.2 & 1.2 & 1.4 & 0.9 & 1.2 \\
\hline Central bank & -0.1 & $\ldots$ & -5.8 & $\ldots$ & 0.3 & -1.6 & -1.4 & -1.2 & -1.1 & -0.8 \\
\hline Commercial banks & 1.2 & $\ldots$ & 1.2 & $\ldots$ & -0.7 & -0.2 & -0.2 & -0.1 & -0.1 & -0.1 \\
\hline Nonbank & -0.8 & $\cdots$ & -0.7 & $\cdots$ & -2.4 & 1.5 & 2.7 & 2.8 & 2.2 & 2.1 \\
\hline External & 0.3 & 0.7 & 0.3 & 0.5 & 0.3 & 0.1 & 0.1 & 0.1 & 0.1 & 0.1 \\
\hline Disbursements & 0.4 & 0.7 & 0.4 & 0.6 & 0.3 & 0.2 & 0.2 & 0.2 & 0.2 & 0.2 \\
\hline Amortization & -0.1 & -0.1 & -0.1 & -0.1 & -0.1 & -0.1 & -0.1 & -0.1 & -0.1 & -0.1 \\
\hline Privatization & $\ldots$ & 1.6 & 1.4 & $\ldots$ & $\ldots$ & $\ldots$ & $\ldots$ & $\ldots$ & $\ldots$ & $\ldots$ \\
\hline \multicolumn{11}{|l|}{ Memorandum items: } \\
\hline Public and publicly guaranteed debt & 38.6 & $\ldots$ & 36.4 & $\ldots$ & 30.6 & 30.0 & 30.6 & 31.2 & 31.1 & 30.9 \\
\hline Public debt & 30.2 & $\ldots$ & 28.2 & $\ldots$ & 22.8 & 22.5 & 23.5 & 24.5 & 24.7 & 25.0 \\
\hline Domestic & 25.7 & $\ldots$ & 22.6 & $\ldots$ & 17.2 & 16.9 & 17.9 & 18.9 & 19.1 & 19.4 \\
\hline External & 4.4 & $\cdots$ & 5.6 & $\ldots$ & 5.6 & 5.6 & 5.6 & 5.6 & 5.6 & 5.6 \\
\hline Publicly guaranteed debt & 8.4 & $\ldots$ & 7.8 & $\ldots$ & 7.8 & 7.5 & 7.1 & 6.7 & 6.3 & 5.9 \\
\hline GDP at current market prices ( $\mathrm{N} \$$ millions) & 41,526 & 44,002 & 48,280 & 50,583 & 53,653 & 59,435 & 65,417 & 72,133 & 79,537 & 87,702 \\
\hline
\end{tabular}

Sources: Namibian authorities; and IMF staff estimates and projections.

1 "Overall balance" reflects externally financed project spending (except for roads) that is not channeled through the state account.

"Overall balance excluding extrabudgetary spending" excludes such spending and thus corresponds directly with the authorities' concept. 
Table 4. Namibia: Monetary Developments, 2004-12

(N\$ millions, end of period)

\begin{tabular}{|c|c|c|c|c|c|c|c|c|c|}
\hline & 2004 & 2005 & 2006 & 2007 & 2008 & 2009 & 2010 & 2011 & 2012 \\
\hline & Dec. & Dec. & Dec. & Dec. & Dec. & Dec. & Dec. & Dec. & Dec. \\
\hline & & & \multicolumn{7}{|c|}{ Projections } \\
\hline \multicolumn{10}{|l|}{ Bank of Namibia } \\
\hline Reserve money & $1,238.6$ & $1,372.5$ & $1,532.4$ & $1,761.4$ & $1,981.8$ & $2,234.0$ & $2,529.5$ & $2,866.6$ & $3,250.3$ \\
\hline Currency & 945.8 & $1,026.8$ & $1,151.4$ & $1,303.4$ & $1,446.7$ & $1,608.5$ & $1,795.9$ & $2,006.6$ & $2,242.7$ \\
\hline Reserves & 292.9 & 345.7 & 381.0 & 458.0 & 535.1 & 625.5 & 733.5 & 860.0 & $1,007.6$ \\
\hline Net foreign assets & $1,977.3$ & $1,983.9$ & $3,164.3$ & $5,598.5$ & $6,537.0$ & $7,450.7$ & $8,317.5$ & $9,187.3$ & $10,125.9$ \\
\hline Net domestic assets & -738.7 & -611.4 & $-1,631.9$ & $-3,837.1$ & $-4,555.2$ & $-5,216.7$ & $-5,788.0$ & $-6,320.6$ & $-6,875.6$ \\
\hline Domestic credit & -637.4 & -79.5 & -744.5 & $-3,493.8$ & $-3,765.1$ & $-4,584.0$ & $-5,278.9$ & $-6,002.4$ & $-6,553.8$ \\
\hline Banks & 238.7 & 515.2 & $1,333.0$ & 453.2 & 362.6 & 453.2 & 634.5 & 793.1 & 991.4 \\
\hline Government (net) & -889.7 & -608.1 & $-2,093.3$ & $-3,963.5$ & $-4,144.2$ & $-5,053.8$ & $-5,929.9$ & $-6,812.1$ & $-7,561.8$ \\
\hline Other sectors & 13.6 & 13.4 & 15.8 & 16.6 & 16.6 & 16.6 & 16.6 & 16.6 & 16.6 \\
\hline Other items net & -101.3 & -531.9 & -887.4 & -343.3 & -790.1 & -632.6 & -509.1 & -318.2 & -321.7 \\
\hline \multicolumn{10}{|l|}{ Monetary survey } \\
\hline Broad money & $15,828.9$ & $17,370.2$ & $22,540.2$ & $26,773.5$ & $30,519.6$ & $34,850.8$ & $39,965.4$ & $45,866.0$ & $52,655.1$ \\
\hline Currency & 632.7 & 680.0 & 763.4 & 803.2 & 897.3 & $1,003.7$ & $1,127.0$ & $1,265.9$ & $1,421.7$ \\
\hline Deposits & $15,196.2$ & $16,690.2$ & $21,771.0$ & $25,970.3$ & $29,622.3$ & $33,847.1$ & $38,838.3$ & $44,600.1$ & $51,233.4$ \\
\hline Net foreign assets & 970.3 & -156.3 & $4,844.5$ & $8,454.9$ & $9,690.9$ & $10,691.2$ & $12,203.0$ & $14,414.7$ & $16,853.8$ \\
\hline Net domestic assets & $14,858.6$ & $17,526.5$ & $17,695.7$ & $18,318.6$ & $20,828.7$ & $24,159.6$ & $27,762.3$ & $31,451.3$ & $35,801.3$ \\
\hline Domestic credit & $21,169.4$ & $25,670.1$ & $28,397.5$ & $29,496.2$ & $32,620.4$ & $35,795.5$ & $39,624.7$ & $43,999.2$ & $49,419.0$ \\
\hline Private sector & $19,918.7$ & $23,922.4$ & $27,436.6$ & $30,495.8$ & $33,871.4$ & $37,930.7$ & $42,592.0$ & $47,788.2$ & $53,869.8$ \\
\hline Government (net) & 871.7 & $1,405.7$ & 113.3 & $-1,941.7$ & $-2,297.4$ & $-3,307.0$ & $-4,283.1$ & $-5,265.3$ & $-6,115.0$ \\
\hline Others $^{1}$ & 379.0 & 342.0 & 847.6 & 942.1 & $1,046.4$ & $1,171.8$ & $1,315.8$ & $1,476.3$ & $1,664.2$ \\
\hline Other items net & $-6,310.8$ & $-8,143.6$ & $-10,701.8$ & $-11,177.6$ & $-11,791.6$ & $-11,635.9$ & $-11,862.4$ & $-12,548.0$ & $-13,617.8$ \\
\hline \multicolumn{10}{|l|}{ Memorandum items: } \\
\hline \multicolumn{10}{|l|}{ Annual percent change } \\
\hline Reserve money & 5.6 & 10.8 & 11.7 & 14.9 & 12.5 & 12.7 & 13.2 & 13.3 & 13.4 \\
\hline Broad money & 16.2 & 9.7 & 29.8 & 18.8 & 14.0 & 14.2 & 14.7 & 14.8 & 14.8 \\
\hline Private sector credit & 19.4 & 20.1 & 14.7 & 11.2 & 11.1 & 12.0 & 12.3 & 12.2 & 12.7 \\
\hline Velocity & 2.4 & 2.4 & 2.3 & 2.0 & 1.9 & 1.8 & 1.8 & 1.7 & 1.6 \\
\hline Money multiplier & 12.8 & 12.7 & 14.7 & 15.2 & 15.4 & 15.6 & 15.8 & 16.0 & 16.2 \\
\hline Exchange rate (N\$/US\$) & 5.6 & 6.3 & 7.0 & $\ldots$ & $\ldots$ & $\ldots$ & $\ldots$ & $\ldots$ & $\ldots$ \\
\hline Net foreign assets (US\$ millions) & 172.3 & -24.7 & 695.1 & $1,181.6$ & $1,321.6$ & $1,411.9$ & $1,560.9$ & $1,785.9$ & $2,024.5$ \\
\hline Bank of Namibia & 351.2 & 313.7 & 454.0 & 782.4 & 891.5 & 984.0 & $1,063.9$ & $1,138.2$ & $1,216.3$ \\
\hline Commercial banks & -178.9 & -338.4 & 241.1 & 399.2 & 430.1 & 427.9 & 497.0 & 647.6 & 808.2 \\
\hline \multicolumn{10}{|l|}{ Domestic interest rates (end of period) } \\
\hline Deposit rate & 6.4 & 6.0 & 6.9 & $\ldots$ & $\ldots$ & $\ldots$ & $\ldots$ & $\ldots$ & $\ldots$ \\
\hline Lending rate & 10.7 & 10.8 & 12.4 & $\ldots$ & $\ldots$ & $\ldots$ & $\ldots$ & $\ldots$ & $\ldots$ \\
\hline Bank rate $^{2}$ & 7.5 & 7.0 & 9.0 & $\ldots$ & $\ldots$ & $\ldots$ & $\ldots$ & $\ldots$ & $\ldots$ \\
\hline 3-month T-bill rate & 7.5 & 7.0 & 8.7 & $\ldots$ & $\ldots$ & $\ldots$ & $\ldots$ & $\ldots$ & $\ldots$ \\
\hline
\end{tabular}

Sources: Bank of Namibia; and IMF staff estimates and projections.

${ }^{1}$ "Others" includes local and regional government and nonfinancial public enterprises.

${ }^{2}$ BoN overdraft rate. 
Table 5. Namibia: Millennium Development Goals, 1990-2005

\begin{tabular}{|c|c|c|c|c|}
\hline & 1990 & 1995 & 2000 & 2005 \\
\hline \multicolumn{5}{|l|}{ Eradicate extreme poverty and hunger ${ }^{1}$} \\
\hline Income share held by lowest $20 \%$ & .. & 1.4 &.. & .. \\
\hline Malnutrition prevalence, weight for age ( $\%$ of children under 5 ) & 26.2 &.. & 24.0 & .. \\
\hline Poverty gap at $\$ 1$ a day (PPP) (\%) &.. & 14.0 &.. & .. \\
\hline Poverty headcount ratio at $\$ 1$ a day (PPP) (\% of population) & .. & 34.9 & .. & .. \\
\hline Prevalence of undernourishment (\% of population) & 34.0 & 35.0 &.. & 24.0 \\
\hline \multicolumn{5}{|l|}{ Achieve universal primary education ${ }^{2}$} \\
\hline Literacy rate, youth total (\% of people ages $15-24$ ) & 87.0 & .. & .. & 92.0 \\
\hline Persistence to grade 5 , total (\% of cohort) & 62.0 & .. & 94.0 & 85.0 \\
\hline Primary completion rate, total ( $\%$ of relevant age group) &.. & 74.0 & 85.0 & 75.0 \\
\hline School enrollment, primary (\% net) & .. &.. & 74.0 & 72.0 \\
\hline \multicolumn{5}{|l|}{ Promote gender equality and empower women ${ }^{3}$} \\
\hline Proportion of seats held by women in national parliament $(\%)$ & 7.0 & 18.0 & 22.0 & 27.0 \\
\hline Ratio of girls to boys in primary and secondary education (\%) & 108.0 &.. & 105.0 & 101.0 \\
\hline Ratio of young literate females to males (\% ages $15-24)$ & 104.0 & .. & .. & 103.0 \\
\hline Share of women employed in the nonagricultural sector ( $\%$ of total employment) & .. & .. & 48.8 & .. \\
\hline \multicolumn{5}{|l|}{ Reduce child mortality ${ }^{4}$} \\
\hline Immunization, measles (\% of children ages 12-23 months) & 57.0 & 68.0 & 69.0 & 73.0 \\
\hline Mortality rate, infant (per 1,000 live births) & 60.0 & 55.0 & 50.0 & 46.0 \\
\hline Mortality rate, under-5 (per 1,000$)$ & 86 & 77.0 & 69.0 & 62.0 \\
\hline \multicolumn{5}{|l|}{ Improve maternal health ${ }^{5}$} \\
\hline Births attended by skilled health staff (\% of total) & 68 & .. & 76.0 & .. \\
\hline Maternal mortality ratio (modeled estimate, per 100,000 live births) & .. &.. & 300.0 &.. \\
\hline \multicolumn{5}{|l|}{ Combat HIVIAIDS, malaria, and other diseases ${ }^{6}$} \\
\hline Contraceptive prevalence (\% of women ages $15-49$ ) & 29 &.. & 44.0 & .. \\
\hline Incidence of tuberculosis (per 100,000 people) & 260.0 & 456.0 & 623.0 & 697.0 \\
\hline Prevalence of HIV, female (\% ages $15-24)$ &.. &.. &.. & 13.4 \\
\hline Prevalence of HIV, total (\% of population ages $15-49$ ) & .. &.. &.. & 19.6 \\
\hline Tuberculosis cases detected under DOTS (\%) & .. & 22.0 & 83.0 & 90.0 \\
\hline \multicolumn{5}{|l|}{ Ensure environmental sustainability ${ }^{7}$} \\
\hline CO2 emissions (metric tons per capita) & 0.0 & 1.0 & 0.9 & 1.2 \\
\hline Forest area ( $\%$ of land area) & 11.0 &.. & 10.0 & 9.0 \\
\hline GDP per unit of energy use (constant 2000 PPP \$ per kg of oil equivalent) & 12.3 & 10.3 & 11.1 & 10.2 \\
\hline Improved sanitation facilities (\% of population with access) & 24.0 &.. &.. & 25.0 \\
\hline Improved water source (\% of population with access) & 57.0 & .. & .. & 87.0 \\
\hline Nationally protected areas ( $\%$ of total land area) &.. & .. & .. & 5.6 \\
\hline \multicolumn{5}{|l|}{ Develop a global partnership for development ${ }^{8}$} \\
\hline Fixed line and mobile phone subscribers (per 1,000 people) & 38.0 & 50.0 & 101.0 & 206.0 \\
\hline Personal computers (per 1,000 people) & .. & 12.0 & 40.0 & 109.0 \\
\hline Unemployment, youth total (\% of total labor force ages $15-24$ ) & 38.1 & 31.7 & 44.8 & .. \\
\hline
\end{tabular}

Source: World Development Indicators database, April 2007.

${ }^{1}$ Goal 1 targets: Halve, between 1990 and 2015, the proportion of people whose income is less than US\$1 a day. Halve, between 1990 and 2015, the proportion of people who suffer from hunger.

${ }^{2}$ Goal 2 target: Ensure that, by 2015, children everywhere, boys and girls alike, will be able to complete a full course of primary schooling.

${ }^{3}$ Goal 3 target: Eliminate gender disparity in primary and secondary education preferably by 2005 and to all levels of education no later than 2015 .

${ }^{4}$ Goal 4 target: Reduce by two-thirds, between 1990 and 2015, the under-five mortality rate.

${ }^{5}$ Goal 5 target: Reduce by three-quarters, between 1990 and 2015, the maternal mortality rate.

${ }^{6}$ Goal 6 targets: Have halted by 2015, and begun to reverse, the spread of HIVIAIDS. Have halted by 2015, and begun to reverse, the incidence of malaria and other major diseases.

${ }^{7}$ Goal 7 targets: Integrate the principles of sustainable development into country policies and programs and reverse the loss of environmental resol Halve, by 2015 , the proportion of people without sustainable access to safe drinking water

${ }^{8}$ Goal 8 targets: Develop further an open, rule-based, predictable, non discriminatory trading and financial system. Address the special seeds of the least developed countries. Address the special needs of landlocked countries and small island developing nations. 
Table 6. Namibia: Financial Sector Indicators, 2002-07

(Percent, unless otherwise indicated)

\begin{tabular}{|c|c|c|c|c|c|c|}
\hline & 2002 & 2003 & 2004 & 2005 & 2006 & $\begin{array}{r}\text { Sep } \\
2007\end{array}$ \\
\hline \multicolumn{7}{|l|}{ Banking indicators } \\
\hline \multicolumn{7}{|l|}{ Capital adequacy } \\
\hline Capital to assets & 7.5 & 8.3 & 8.8 & 7.8 & 7.5 & 7.3 \\
\hline Regulatory capital to risk-weighted assets & 14.1 & 14.8 & 15.4 & 14.6 & 14.2 & 14.8 \\
\hline Regulatory tier I capital to risk-weighted assets & 11.0 & 12.2 & 12.7 & 11.2 & 11.1 & 10.9 \\
\hline Nonperforming loans net of provisions to capital & 11.6 & 14.3 & 1.1 & 3.0 & 2.5 & 6.4 \\
\hline \multicolumn{7}{|l|}{ Asset quality } \\
\hline Large exposure to capital & 207.2 & 190.2 & 181.2 & 182.8 & 189.3 & 170.8 \\
\hline Nonperforming loans to total gross loans & 3.5 & 3.9 & 2.4 & 2.3 & 2.6 & 2.9 \\
\hline \multicolumn{7}{|l|}{ Sectoral distribution of loans to total loans } \\
\hline Agriculture & 8.6 & 5.5 & 3.1 & 3.9 & 3.0 & 2.7 \\
\hline Mining & 1.5 & 2.6 & 2.0 & 2.8 & 0.7 & 1.9 \\
\hline Manufacturing & 5.4 & 3.8 & 2.3 & 1.8 & 2.4 & 2.1 \\
\hline Construction & 4.5 & 4.1 & 5.5 & 1.5 & 1.6 & 1.6 \\
\hline Electricity and water & 4.4 & 3.4 & 0.7 & 0.8 & 0.3 & 0.3 \\
\hline Trade and accommodation & 5.2 & 2.6 & 3.7 & 4.1 & 5.1 & 5.3 \\
\hline Transport and communications & 3.6 & 4.6 & 2.3 & 3.1 & 3.1 & 1.3 \\
\hline Finance, real estate, and business services & 11.1 & 9.6 & 11.4 & 13.2 & 15.8 & 19.6 \\
\hline Other services (including government) & 7.0 & 8.6 & 8.2 & 6.8 & 4.1 & 4.6 \\
\hline Individuals & 47.1 & 47.1 & 51.2 & 54.9 & 56.4 & 58.0 \\
\hline Other & 1.8 & 8.3 & 9.4 & 7.1 & 7.6 & 2.6 \\
\hline \multicolumn{7}{|l|}{ Earnings and profitability } \\
\hline Trading income to total income & 3.0 & 4.2 & 7.5 & 3.8 & 3.7 & 6.0 \\
\hline Return on assets & 4.5 & 3.6 & 2.1 & 3.5 & 1.5 & 3.1 \\
\hline Return on equity & 59.8 & 43.2 & 24.2 & 45.6 & 19.9 & 43.0 \\
\hline Interest margin to gross income & 53.0 & 51.3 & 57.0 & 49.8 & 53.7 & 53.4 \\
\hline Noninterest expenses to gross income & 49.3 & 58.1 & 69.2 & 54.9 & 63.7 & 54.8 \\
\hline Spread between reference lending and deposit rates & 6.2 & 6.0 & 4.4 & 4.8 & 5.6 & 5.9 \\
\hline Personnel expenses to noninterest expenses & 48.4 & 43.8 & 47.1 & 47.8 & 39.6 & 50.9 \\
\hline \multicolumn{7}{|l|}{ Liquidity } \\
\hline Spread between highest and lowest interbank rate & 4.0 & 9.0 & 0.2 & 5.3 & 10.3 & 1.1 \\
\hline Liquid assets to total assets & 1.9 & 2.4 & 1.3 & 1.2 & 1.0 & 0.8 \\
\hline Liquid assets to short-term liabilities & 9.4 & 11.0 & 10.4 & 9.5 & 9.1 & 7.3 \\
\hline Customer deposits to total (non-interbank) loans & 84.3 & 87.4 & 87.1 & 94.6 & 101.8 & 104.9 \\
\hline \multicolumn{7}{|l|}{ Exposure to foreign exchange risk } \\
\hline Net open position in foreign exchange to capital & 0.1 & 0.0 & 0.5 & 1.4 & 0.3 & 0.5 \\
\hline Foreign currency-denominated loans to total loans & 5.0 & 3.0 & 1.9 & 0.7 & 1.0 & 0.1 \\
\hline Foreign currency-denominated liabilities to total liabilities & 5.2 & 4.5 & 2.0 & 1.1 & 2.5 & 2.0 \\
\hline \multicolumn{7}{|l|}{ Financial system structure } \\
\hline \multicolumn{7}{|l|}{ Number } \\
\hline Banks & 5 & 4 & 4 & 4 & 4 & 4 \\
\hline Private commercial & 2 & 1 & 1 & 1 & 1 & 1 \\
\hline State-owned & 0 & 0 & 0 & 0 & 0 & 0 \\
\hline Foreign-owned subsidiaries & 3 & 3 & 3 & 3 & 3 & 3 \\
\hline Branches of foreign banks & 0 & 0 & 0 & 0 & 0 & 0 \\
\hline \multicolumn{7}{|l|}{ Assets (N\$ billions) } \\
\hline Banks & 17.8 & 20.0 & 23.4 & 28.2 & 33.4 & 36.2 \\
\hline Private commercial & 5.7 & 4.3 & 5.2 & 6.8 & 8 & 9.5 \\
\hline State-owned & $\ldots$ & $\ldots$ & 0 & 0 & 0 & 0 \\
\hline Foreign-owned subsidiaries & 12.1 & 15.8 & 18.2 & 21.4 & 25.4 & 26.7 \\
\hline Branches of foreign banks & $\ldots$ & $\ldots$ & 0 & 0 & 0 & 0 \\
\hline \multicolumn{7}{|l|}{ Deposits ( $\mathrm{N} \$$ billions) } \\
\hline Banks & 12.7 & 14.3 & 17.2 & 21.5 & 26.4 & 28.9 \\
\hline Private commercial & 4.7 & 3.5 & 2.5 & 5.5 & 6.9 & 8.1 \\
\hline State-owned & $\ldots$ & $\ldots$ & 0.0 & 0 & 0 & 0 \\
\hline Foreign-owned subsidiaries & 7.9 & 10.7 & 14.7 & 16 & 19.5 & 20.8 \\
\hline Branches of foreign banks & $\ldots$ & $\ldots$ & 0.0 & 0 & 0 & 0 \\
\hline
\end{tabular}

Sources: Bank of Namibia; and IMF staff estimates. 
Table 7. Namibia: Indicators of External and Financial Vulnerability, 2001-07

\begin{tabular}{|c|c|c|c|c|c|c|c|c|}
\hline & 2001 & 2002 & 2003 & 2004 & 2005 & 2006 & Latest & $\begin{array}{c}\text { Date of } \\
\text { Latest } \\
\text { Observation }\end{array}$ \\
\hline \multicolumn{9}{|l|}{ Financial indicators } \\
\hline Public sector debt of the central government ${ }^{1}$ & 25.9 & 23.9 & 29.6 & 33.7 & 30.2 & 28.2 & -- & Mar. 2007 \\
\hline Broad money (percent change, 12-month basis) & 4.5 & 6.9 & 9.6 & 16.2 & 9.7 & 29.8 & 19.5 & Sept. 2007 \\
\hline Private sector credit (percent change, 12-month basis) & 16.3 & 20.2 & 12.4 & 19.4 & 20.1 & 14.7 & 12.1 & Sept. 2007 \\
\hline Bank of Namibia overdraft interest rate (bank rate) ${ }^{2}$ & 9.3 & 12.8 & 7.8 & 7.5 & 7.0 & 9.0 & 10.5 & Oct. 2007 \\
\hline Bank of Namibia overdraft real interest rate ${ }^{23}$ & 1.0 & 0.3 & 5.2 & 3.2 & 3.5 & 3.0 & 3.9 & Oct. 2007 \\
\hline \multicolumn{9}{|l|}{ External indicators } \\
\hline Exports (percent change, 12-month basis in US\$) & -13.5 & -6.1 & 16.6 & 45.8 & 13.3 & 28.3 & -- & Dec. 2006 \\
\hline Imports (percent change, 12-month basis in US\$) & 2.3 & -4.6 & 33.7 & 23.1 & 10.7 & 9.7 & -- & Dec. 2006 \\
\hline Terms of trade (percent change, 12-month basis) & 0.5 & 0.5 & 0.2 & 8.5 & 4.8 & 11.1 & -- & Dec. 2006 \\
\hline Current account balance & 1.9 & 3.7 & 6.7 & 8.2 & 5.5 & 15.9 & -- & Dec. 2006 \\
\hline Capital and financial account balance & 0.0 & 0.0 & 0.0 & 0.0 & 0.0 & 0.0 & -- & Dec. 2006 \\
\hline Gross official reserves (US\$ millions) ${ }^{2}$ & 224.0 & 336.2 & 318.9 & 352.7 & 315.9 & 512.7 & 823.5 & Sept. 2007 \\
\hline Official reserves in months of imports of goods and services ${ }^{2}$ & 1.7 & 2.7 & 1.9 & 1.7 & 1.4 & 2.1 & 3.3 & Sept. 2007 \\
\hline Broad money to reserves & 5.2 & 3.5 & 5.6 & 7.0 & 8.6 & 6.5 & 4.5 & Sept. 2007 \\
\hline Reserves/total short-term external debt ${ }^{2}$ & 1.5 & 1.1 & 0.5 & 0.5 & 0.5 & 0.6 & -- & Dec. 2006 \\
\hline Total external debt (US\$ millions) ${ }^{2}$ & 0.0 & 0.0 & 0.0 & 0.0 & 0.0 & 0.0 & -- & Dec. 2006 \\
\hline Of which: public sector debt (US\$ millions) & 0.0 & 0.0 & 0.0 & 0.0 & 0.0 & 0.0 & -- & Dec. 2006 \\
\hline Total external debt to exports of goods and services ${ }^{2}$ & 0.0 & 0.0 & 0.0 & 0.0 & 0.0 & 0.0 & -- & Dec. 2006 \\
\hline Nominal exchange rate (N\$/US\$, period average) & 8.6 & 10.5 & 7.6 & 6.4 & 6.4 & 6.8 & 6.9 & Sep. 2007 \\
\hline Real effective exchange rate (percent change, depreciation $=-$ ) & -5.0 & -8.3 & 20.0 & 7.0 & 0.7 & -2.7 & -- & Dec. 2006 \\
\hline \multicolumn{9}{|l|}{ Financial market indicators } \\
\hline End-of-period stock market index & 392.0 & 305.0 & 347.0 & 425.9 & 581.7 & 852.8 & $1,022.4$ & Oct. 10,2007 \\
\hline
\end{tabular}

Sources: Namibian authorities; and IMF staff estimates.

${ }^{1}$ Fiscal years, which begin on April 1.

${ }^{2}$ End of period.

${ }^{3}$ Deflated by the percentage change in end-of-period CPI. 
Table 8. Namibia: Social and Demographic Indicators, 2007

\begin{tabular}{|c|c|c|c|}
\hline & Namibia & South Africa & $\begin{array}{c}\text { Sub-Saharan } \\
\text { Africa }\end{array}$ \\
\hline Area (thousands of square kilometers) & 824 & 1,219 & 24,265 \\
\hline \multicolumn{4}{|l|}{ Population (2005) } \\
\hline Total (millions) & 2.0 & 46.9 & 743.0 \\
\hline Annual rate of growth (percent) ${ }^{1}$ & 1.0 & 0.1 & 2.2 \\
\hline \multicolumn{4}{|l|}{ Population characteristics } \\
\hline Population density (per square kilometer) & 2.4 & 38.5 & 30.6 \\
\hline Urban population (percent of total) & 32 & 59 & 36 \\
\hline \multicolumn{4}{|l|}{ Population age structure (percent of total) } \\
\hline $0-14$ years & 41.5 & 32.6 & 43.5 \\
\hline $15-64$ years & 55.0 & 63.1 & 53.4 \\
\hline 65 years and above & 3.5 & 4.3 & 3.1 \\
\hline \multicolumn{4}{|l|}{ Income distribution ${ }^{2}$} \\
\hline Income share held by highest 20 percent & 78.7 & 62.2 & $\ldots$ \\
\hline Income share held by lowest 20 percent & 1.4 & 3.5 & $\ldots$ \\
\hline \multicolumn{4}{|c|}{ Access to improved water source (percent of population, 2004) } \\
\hline Total & 87 & 88 & 56 \\
\hline Rural & 79 & 73 & 44 \\
\hline Urban & 98 & 98 & 82 \\
\hline \multicolumn{4}{|l|}{ Health (2005) } \\
\hline Life expectancy at birth & 47 & 48 & 47 \\
\hline Infant mortality (per 1,000 live births) & 46 & 55 & 96 \\
\hline People living with HIVIAIDS ${ }^{3}$ & 19.6 & 18.8 & 5.8 \\
\hline PPP gross national income per capita (2005) & 7,690 & 10,880 & 1,913 \\
\hline \multicolumn{4}{|l|}{ Labor force (2005) } \\
\hline Total (millions) & 0.6 & 19.2 & 306.0 \\
\hline Female (percent of total population) & 43.6 & 38.2 & 42.1 \\
\hline \multicolumn{4}{|l|}{ Education (2005) } \\
\hline \multicolumn{4}{|l|}{ School enrollment (percent, gross) } \\
\hline Primary & 99 & 104 & 92 \\
\hline Secondary & 61 & 93 & 30 \\
\hline Tertiary & 6 & 16 & 5 \\
\hline Adult literacy rate & 85.0 & 82.5 & 61.5 \\
\hline
\end{tabular}

Source: World Bank, World Development Indicators, 2007.

${ }^{1}$ Based on 2005 data from the United Nations Populations Division.

${ }^{2}$ Based on latest household income and expenditure survey.

${ }^{3}$ Reflects prevalence rate in sentinel survey. 


\section{INTERNATIONAL MONETARY FUND}

\section{NAMIBIA \\ Staff Report for the 2007 Article IV Consultation \\ Informational Annex}

Prepared by the African Department

January 2, 2008

- Relations with the Fund. Describes Namibia's membership status, exchange arrangement, and financial and technical assistance from the Fund.

- Relations with the World Bank. Describes the World Bank Group program.

- $\quad$ Statistical Issues. Assesses the quality of the statistical data. Namibia's statistical coverage is generally good but some data are not timely.

- $\quad$ Fiscal Debt Sustainability Analysis. Examines the long run sustainability of Namibia's public debt. It finds that Namibia has moderate public debt ratios that are robust to most economic shocks. 


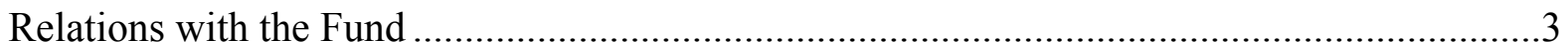

Relations with the World Bank ...................................................................................

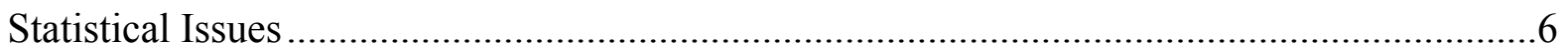

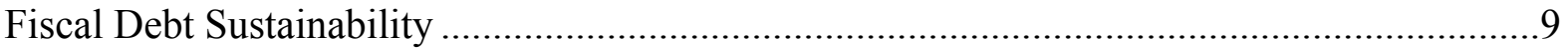

Table

1. Public Sector Debt Sustainability Framework, 2002-12 …....................................10

Figure

1. Public Debt Sustainability: Bound Tests ..........................................................11 


\section{APPENDIX I \\ NAMIBIA: RELATIONS WITH THE FUND}

(As of November 30, 2007)

Membership Status

General Resources Account

Quota

Fund holdings of currency

Reserve position in Fund

SDR Department

Holdings

Outstanding purchases and loans

Financial arrangements

Projected obligations to Fund
Joined 9/25/90; Article VIII

\begin{tabular}{rr} 
SDR (million) & \% of Quota \\
\hline 136.50 & 100.0 \\
136.43 & 99.95 \\
0.08 & 0.06 \\
SDR (million) & \% of Allocation \\
\cline { 2 - 2 } & N/A
\end{tabular}

None

None

None

\section{Exchange rate arrangement}

The Namibia dollar is pegged at par to the South African rand, and both currencies are legal tender in Namibia. Namibia formally accepted the obligations of Article VIII, Sections 2, 3, and 4, of the Fund's Articles of Agreement as of September 20, 1996, and maintains an exchange rate system free of restrictions in the making of transfers and payments of current account transactions.

\section{Article IV consultations}

Namibia is on the standard 12-month Article IV consultation cycle; the last Article IV consultation was concluded by the Executive Board on January 5, 2007.

During the Executive Board meeting, Directors commended Namibia's record of macroeconomic stability and welcomed the recent rise in growth, decline in inflation, and strengthening of external accounts. They emphasized the need to reduce the fiscal deficit through expenditure restraint and civil service reform. They observed that the exchange rate peg had served Namibia well but noted the importance of maintaining adequate international reserves. Directors also stressed the importance of addressing HIV/AIDS, high unemployment, and large disparities of income. 


\section{Technical Assistance:}

\begin{tabular}{|c|c|c|c|c|c|}
\hline Date & Duration & Dept. & Recipient & Purpose & Form \\
\hline $06 / 05$ & 10 days & MFD & Bank of Namibia & Payments oversight & Advisor \\
\hline $02 / 06$ & 2 weeks & FAD & Ministry of Finance & $\begin{array}{l}\text { Modernizing tax } \\
\text { administration } \\
\text { Fiscal regime for } \\
\text { mining and processing }\end{array}$ & $\begin{array}{l}\text { Advisor } \\
\mathrm{g}\end{array}$ \\
\hline $04 / 06$ & 1 weeks & MFD & Bank of Namibia & Payment systems & Advisor \\
\hline $05 / 06$ & 3 weeks & STA & Centr. Bur. Of Stat. & $\begin{array}{l}\text { National accounts } \\
\text { (GDDS project) }\end{array}$ & Advisor \\
\hline $05 / 06$ & 4 days & MFD & $\begin{array}{l}\text { Nonbank Financial } \\
\text { Institution }\end{array}$ & Bank of Namibia & Advisor \\
\hline $06 / 06$ & 2 weeks & STA & Ministry of Finance & GFS (GDDS project) & Advisor \\
\hline $10 / 06$ & 2 weeks & MFD & Bank of Namibia & $\begin{array}{l}\text { Lending policy, } \\
\text { monetary operations, } \\
\text { bank supervision }\end{array}$ & Advisor \\
\hline $10 / 06$ & 4 days & STA & Bank of Namibia & SDDS project & Advisor \\
\hline $03 / 07$ & 2 weeks & MCM & Bank of Namibia & $\begin{array}{l}\text { Risk-based } \\
\text { supervision }\end{array}$ & Advisor \\
\hline $04 / 07$ & 2 weeks & FAD & Ministry of Finance & $\begin{array}{l}\text { Revenue modeling } \\
\text { and forecasting }\end{array}$ & Advisor \\
\hline $06 / 07$ & 2 weeks & FAD & Ministry of Finance & ROSC & Advisor \\
\hline $08 / 07$ & 2 weeks & MCM & Bank of Namibia & Payment systems & Advisor \\
\hline $10 / 07$ & 2 weeks & STA & Bank of Namibia & $\begin{array}{l}\text { Monetary and } \\
\text { financial statistics }\end{array}$ & Advisor \\
\hline
\end{tabular}




\section{APPENDIX II \\ NAMIBIA: RELATIONS WITH THE WORLD BANK GROUP}

(As of December 2007)

1. Namibia joined the World Bank, the International Finance Corporation (IFC), and the Multilateral Investment Guarantee Agency (MIGA) in 1990. The Interim Strategy Note, the first framework for engagement with the Republic of Namibia, was presented to the Board of Executive Directors in May 2007. The strategy focuses on a flexible, demand-driven business model in step with the Government's budget and decision-making processes. Engagement is envisioned at three levels: (i) continued work on education and environment; (ii) building on recent fiduciary and analytical work; and (iii) responses to Government requests for analytical and advisory activities (AAA) based on a collaborative process of setting priorities through broad-based consultations. Lending is envisaged for two Development Policy Loans (DPL) in support of the Government's Education and Training Sector Improvement Program (ETSIP) in the amount of $\$ 15$ million over two years.

2. The Bank is now finalizing a Country Economic Report, prepared jointly with the Government, to identify binding constraints to achieving sustainable growth and reducing poverty and inequality. Support also aims to strengthen poverty diagnosis and build macromicro simulation models that could analyze the macroeconomic, structural, and distributional implications of alternative policies.

3. As part of its AAA services the Bank carried out several diagnostic studies, including a Foreign Investment Advisory Services/MIGA Study on Investment Incentives; an Investment Climate Assessment; and a Financial Sector Assessment Program (jointly with the Fund). The Bank is supporting Namibia's endeavors toward good governance and zero tolerance of corruption by assisting the Anti-Corruption Commission and other law enforcement agencies through technical assistance and advice on spearheading the roll-out of e-governance.

4. A Country Environmental Analysis with a Public Environmental Expenditure Review (CEA/PEER) now underway aims to help the Ministry of Environment and Tourism (MET) review some of the main policy, institutional, and financing challenges it faces. The CEA/PEER is an outcome of the dialogue between the World Bank and the Government of Namibia about sustainable environmental management and complements the program funded by the Global Environmental Facility (GEF) comprising two active projects (on Integrated Community-Based Ecosystem Management and Namibian Coast Conservation and Management) and a small project being prepared to promote environmental sustainability through improved land-use planning.

5. Working in collaboration with the Fund under the Lipsky-Daboub Initiative, the Bank is consulting with the Namibian authorities to strengthen management of natural resources income.

6. An IDF grant of US\$499,000 to support the public-private partnership in the fight against HIV/AIDS will close in March 2009. Further technical assistance is provided by the Global AIDS Monitoring and Evaluation Team (GAMET) on building the country's capacities to monitor and evaluate its interventions.

7. IFC does not have an active portfolio at present, and no new MIGA projects have been executed or are planned. 


\section{APPENDIX III}

\section{NAMIBIA: STATISTICAL ISSUES}

1. While data provision is broadly adequate for surveillance purposes, staff analysis is hampered by significant lags and revisions of key macroeconomic data. As one of 22 countries participating in the Fund's General Data Dissemination System (GDDS) Project for Anglophone African Countries, the country has undertaken to use the GDDS as a framework for the development of their national statistical systems. The country is participating in the SDDS and the monetary and financial statistics modules of the Anglophone Africa project (funded by the U.K. Department for International Development (DFID)). GDDS metadata were posted on the Fund's Dissemination Standards Bulletin Board on December 19, 2002. Since then, metadata on central government debt were updated in November 2003 while metadata for the financial and external sectors were updated in May 2005.

\section{Real sector}

2. The authorities revised the coverage of national accounts over the last three years, by incorporating new mining activity and the value-added of companies operating in Export Processing Zones (EPZs). As a result, real GDP growth in 2002 was revised upward by 4 percentage points, to $63 / 4$ percent, while growth in 2003 remained broadly unchanged. The authorities are in the process of updating the base year of the national accounts from 1995 to 2004. Such estimates will benefit from the 2004 Household Income and Expenditure Survey (HIES), though there remains a paucity of reliable annual and quarterly source data. A regional real sector expert covering Botswana, Mauritius and, Namibia was posted in October 2007 for one year.

3. In February 2005, the government introduced a nation-wide consumer price index to replace the previous index that only covered the capital city of Windhoek. The new index is available from January 2002.

4. Data on the labor market, including labor force, employment, and wages are not systematically collected, which impedes the analysis of labor market developments. The last labor market survey was conducted in 2004.

\section{Government finance}

5. Annual fiscal data on budgetary central government through 2003 are reported to STA for publication in the 2007 GFS Yearbook and in IFS. The data, which are reported on a cash basis in the GFSM 2001 format, are reasonably complete, despite some gaps in terms of details. No data on outstanding debt are reported. The area department receives actual fiscal data several months after the end of the fiscal year. No data on budget implementation during the fiscal year are provided. 
6. Expenditure data of line ministries are not available in a timely manner after the end of the fiscal year, and are also subject to frequent revisions; however, preliminary general ledger data related to the 2005/06 fiscal year were received by the area department relatively quickly following the end of the fiscal year, contrary to past practice. Overall, the system for providing expenditure information needs to be strengthened, and preliminary information on cash expenditures of ministries should be made available on a regular basis and more quickly. In addition, the reconciliation of above-the-line fiscal data with financing data should be conducted on a regular basis and more frequently.

\section{Monetary accounts}

7. Monthly monetary statistics for the Bank of Namibia $(\mathrm{BoN})$ and the other depository corporations (ODCs) are reported on a timely basis. Beginning in April 2002, data are based on standardized report forms which accord with the concepts and definitions of the Monetary and Financial Statistics Manual. Although the consistency in inter-ODCs positions as well as between the ODCs and BoN has improved substantially, the BoN continues working on eliminating any remaining inconsistency. The October 2007 STA technical assistance mission assisted BoN to expand monetary and financial statistics to cover the Other Financial Corporations (OFCs).

\section{External sector statistics}

8. Since 2001, the BoN has been reporting the balance of payments data on a quarterly basis with a lag of one quarter. Those data are subject to substantial revisions. The methodology underlying the balance of payments is consistent with the fifth edition of the IMF's Balance of Payments Manual and is well documented. The international investment position (IIP) data are compiled annually, but dissemination is subject to significant lags. Through a series of three missions between January 2003 and May 2004, the Bank of Namibia received Fund TA to improve the compilation of the capital and financial transactions and IIP statistics. However, further work is needed to expand the coverage of the IIP and restate the IIP in a format that will allow for comparison with the balance of payments statistics and also reporting to STA. 


\section{NAMibia: TABLE OF COMMON INDICATORS REQUIRED FOR SURVEILLANCE}

(as of December 12, 2007)

\begin{tabular}{|c|c|c|c|c|c|c|c|}
\hline & \multirow{2}{*}{$\begin{array}{c}\text { Date of } \\
\text { latest } \\
\text { observation }\end{array}$} & \multirow{2}{*}{$\begin{array}{l}\text { Date } \\
\text { received }\end{array}$} & \multirow{2}{*}{$\begin{array}{c}\text { Frequency } \\
\text { of } \\
\text { Data }^{6}\end{array}$} & \multirow{2}{*}{$\begin{array}{l}\text { Frequency } \\
\text { of } \\
\text { Reporting }^{6}\end{array}$} & \multirow{2}{*}{$\begin{array}{c}\text { Frequency } \\
\text { of } \\
\text { Publication }^{6}\end{array}$} & \multicolumn{2}{|c|}{ Memo Items: } \\
\hline & & & & & & $\begin{array}{c}\text { Data Quality - } \\
\text { Methodological } \\
7^{7} \\
\text { soundness }\end{array}$ & $\begin{array}{c}\text { Data Quality - } \\
\text { Accuracy and } \\
\text { reliability }^{8}\end{array}$ \\
\hline Exchange Rates & Nov. 2007 & Dec. 2007 & $\mathrm{D}$ & $\mathrm{M}$ & $\mathrm{D}$ & & \\
\hline $\begin{array}{l}\text { International Reserve Assets and Reserve } \\
\text { Liabilities of the Monetary Authorities }{ }^{1}\end{array}$ & Aug. 2007 & Oct. 2007 & M & M & M & & \\
\hline Reserve/Base Money & Oct. 2007 & Dec. 2007 & M & M & M & $\mathrm{LO}, \mathrm{O}, \mathrm{O}, \mathrm{LO}$ & $\begin{array}{l}\text { LNO, LNO, } \\
\text { LO, LO, NA }\end{array}$ \\
\hline Broad Money & Oct. 2007 & Dec. 2007 & M & M & M & & \\
\hline Central Bank Balance Sheet & Oct. 2007 & Dec. 2007 & M & M & M & & \\
\hline Consolidated Balance Sheet of the Banking System & Oct. 2007 & Dec. 2007 & M & M & M & & \\
\hline Interest Rates ${ }^{2}$ & Oct. 2007 & Dec. 2007 & M & $\mathrm{M}$ & $\mathrm{M}$ & & \\
\hline Consumer Price Index & Oct. 2007 & Dec. 2007 & M & M & M & $\mathrm{O}, \mathrm{LNO}, \mathrm{LO}, \mathrm{O}$ & $\begin{array}{l}\text { LO, LNO, O, } \\
\text { O, NA }\end{array}$ \\
\hline $\begin{array}{l}\text { Revenue, Expenditure, Balance and Composition of } \\
\text { Financing }{ }^{3}-\text { General Government }\end{array}$ & $\ldots$ & $\cdots$ & I or NA & I or NA & I or NA & $\begin{array}{l}\text { LNO, LNO, } \\
\text { LO, O }\end{array}$ & $\begin{array}{l}\mathrm{O}, \mathrm{O}, \mathrm{O}, \mathrm{LO}, \\
\mathrm{NA}\end{array}$ \\
\hline $\begin{array}{l}\text { Revenue, Expenditure, Balance and Composition of } \\
\text { Financing }{ }^{3} \text { - Central Government }\end{array}$ & Mar. 2007 & Jun. 2007 & $\begin{array}{c}\text { I, NA } \\
\text { (Comp. of } \\
\text { Financing } \\
\text { ) } \\
\end{array}$ & $\begin{array}{c}\text { I, NA } \\
\text { (Comp. of } \\
\text { Financing) }\end{array}$ & $\begin{array}{c}\text { I, NA } \\
\text { (Comp. of } \\
\text { Financing) }\end{array}$ & & \\
\hline $\begin{array}{l}\text { Stocks of Central Government and Central } \\
\text { Government-Guaranteed Debt }\end{array}$ & Jun. 2007 & Oct. 2007 & $\begin{array}{l}\text { M, I } \\
\text { (Gov.-Guar. } \\
\text { Debt) }\end{array}$ & $\begin{array}{l}\text { M, I } \\
\text { (Gov.-Guar. } \\
\text { Debt) }\end{array}$ & $\begin{array}{l}\text { M, I } \\
\text { (Gov.-Guar. } \\
\text { Debt) }\end{array}$ & & \\
\hline External Current Account Balance & Q2 2007 & Oct. 2007 & Q & Q & Q & $\mathrm{O}, \mathrm{O}, \mathrm{O}, \mathrm{LO}$ & $\begin{array}{l}\text { LO, LO, LO, } \\
\text { LNO, NO }\end{array}$ \\
\hline Exports and Imports of Goods and Services & Q2 2006 & Oct. 2007 & Q & Q & Q & & \\
\hline GDP/GNP & 2006 & Nov. 2007 & A & A & A & $\mathrm{O}, \mathrm{O}, \mathrm{O}, \mathrm{LO}$ & $\begin{array}{l}\text { LNO, LO, LO, } \\
\text { LO, O }\end{array}$ \\
\hline Gross External Debt & 2006 & Oct. 2007 & A & A & A & & \\
\hline
\end{tabular}

${ }^{1}$ Includes reserve assets pledged or otherwise encumbered as well as net derivative positions.

${ }^{2}$ Both market-based and officially-determined, including discount rates, money market rates, rates on treasury bills, notes and bonds.

${ }^{3}$ Foreign, domestic bank, and domestic nonbank financing.

${ }^{4}$ The general government consists of the central government (budgetary funds, extra budgetary funds, and social security funds) and state and local governments.

${ }^{5}$ Including currency and maturity composition.

${ }^{6}$ Daily (D); weekly (W); monthly (M); quarterly (Q); annually (A); irregular (I); and not available (NA).

${ }^{7}$ Reflect the assessments provided in the data ROSC Substantive Update and the data ROSC module published, respectively, in September 2005 and September 2002, and based on the findings of the missions that took place during April 2005 and January 2001) for the dataset corresponding to the variable in each row. The assessment indicates whether international standards concerning concepts and definitions, scope, classification/sectorization, and basis for recording are fully observed (O); largely observed (LO); largely not observed (LNO); not observed (NO); and not available (NA).

${ }^{8}$ Same as footnote 7, except referring to international standards concerning source data, statistical techniques, assessment and validation of source data, assessment, and revision studies. 


\section{APPENDIX IV \\ Namibia: Fiscal Debt Sustainability}

1. Namibia's public debt is low due to substantial fiscal consolidation over the last three years. On a calendar-year basis, in 2006 public debt fell approximately $3 \frac{1 / 4}{4}$ percentage points, to $28 \frac{1}{2}$ percent of GDP, due in part to receipts from privatization of a telecommunications firm. This decrease followed a $1 \frac{1}{4}$ percentage point fall in 2005 . On current projections, the debt-to-GDP ratio will fall to $22 \frac{1}{2}$ percent in 2008 before rising gradually to the authorities' target of 25 percent by 2012, as capital spending rises.

2. The first panel of Table 1 corresponds to the baseline scenario underlying the macroeconomic framework. It assumes the central government budget balance has a surplus of 23/4 percent of GDP in 2007 before declining gradually to a 11/4 percent deficit by 2012 . Revenues decline by approximately $2 \frac{1}{2}$ percent of GDP over the period as customs union (SACU) revenues decline. Declines in mining income are offset by increases in personal income and VAT taxes. On the expenditure side, an increase of 1 percent of GDP in capital spending in 2009 and 2010 and increased expenditures on goods and services causes total expenditures to rise to 35 percent of GDP before falling back to $34 \frac{1}{2}$ percent by 2012 . As a result, public debt declines to $22 \frac{1}{2}$ percent of GDP in 2008 before stabilizing at the authorities' 25 percent target. Robust nominal GDP growth (projected to average 9 percent over the period) also helps to keep the public debt-to-GDP ratio stable.

3. Table 1 shows two additional scenarios. The first shows the fiscal outcome if real GDP growth, real interest rates, and the primary balance are maintained at their historical averages. In this case, because Namibia had substantial deficits in past years, the public debt ratio would rise to approximately 33 percent of GDP by 2012. The second scenario shows the outcome if the government maintains the 5 percent of GDP primary surplus estimated for 2007. In this case the public debt ratio rapidly declines to less than 5 percent of GDP by the end of the forecast period.

4. The bounds tests illustrate the vulnerability of the fiscal position to exogenous shocks (Figure 1). The results show that even with a half standard deviation shock to interest rates, growth, or the exchange rate, the debt-to-GDP ratio would remain at or below 31 percent of GDP.

5. To date the authorities have shown thorough commitment to fiscal prudence and to achieving their target public debt ratio of 25 percent of GDP. They have been helped in these efforts by positive shocks to both SACU revenues and diamond production. At the same time, they have been able to contain expenditures on personnel and goods and service and public debt appears robust to most economic shocks. 


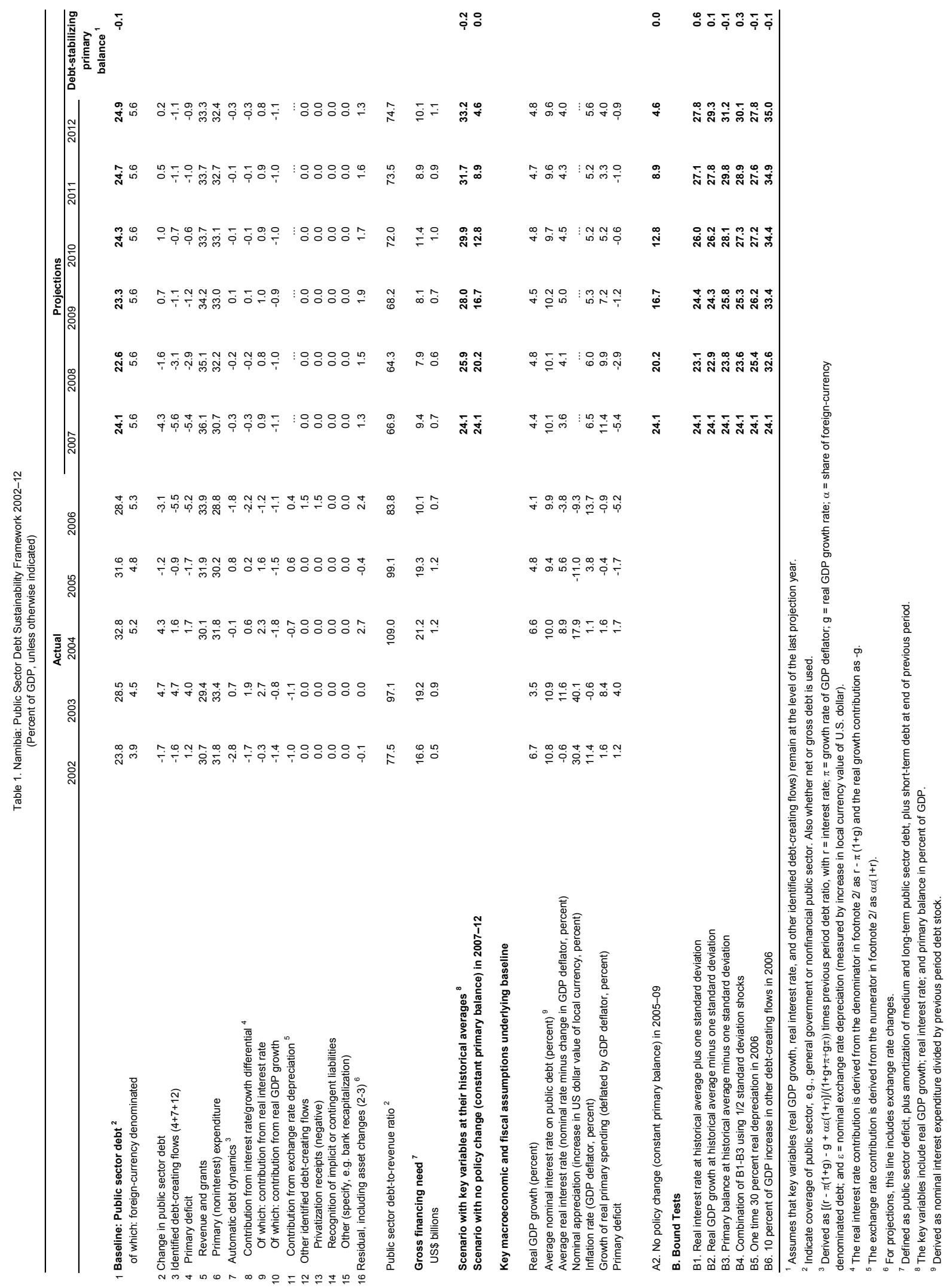


Figure 1. Namibia: Public Debt Sustainability: Bound Tests ${ }^{1}$ (Public debt in percent of GDP)

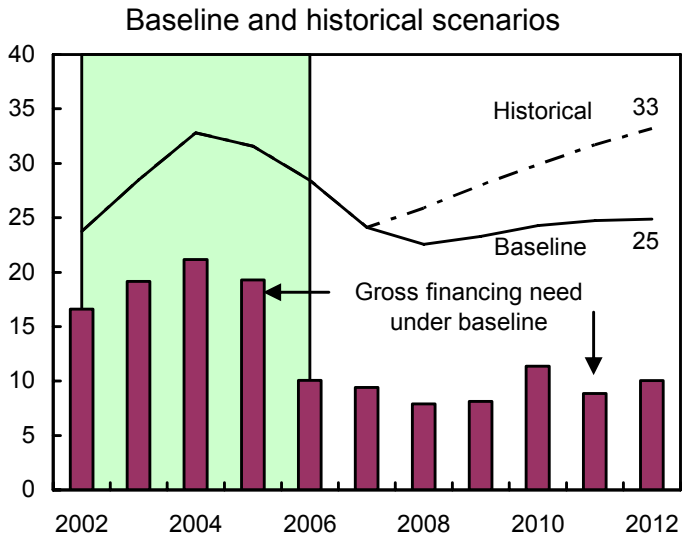

Growth shock (percent per year)

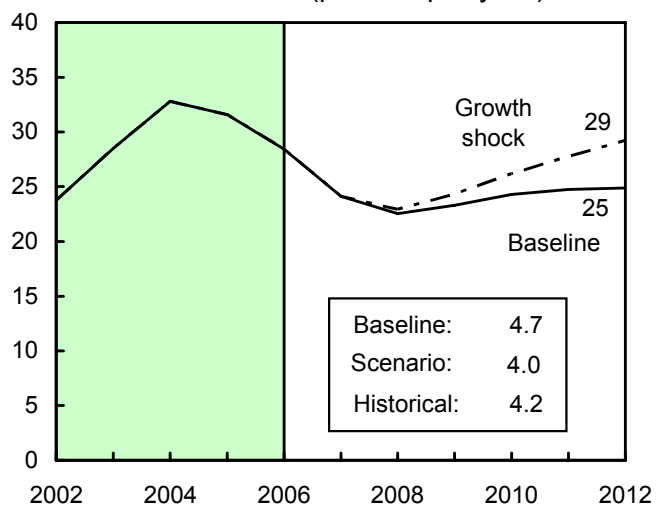

Combined shock ${ }^{2}$

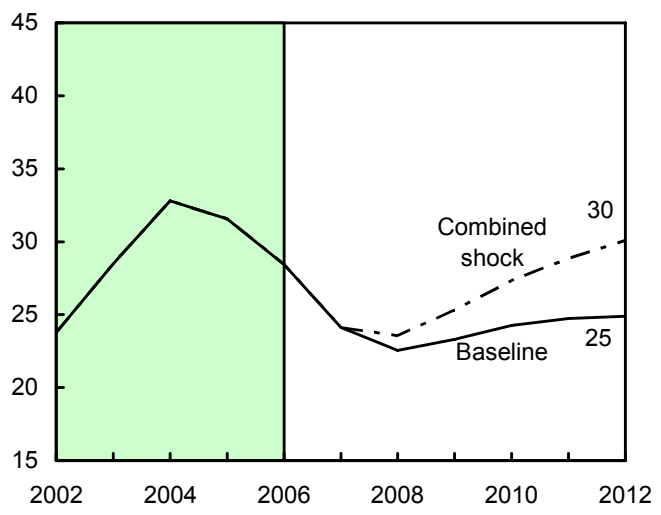

Interest rate shock (percent)

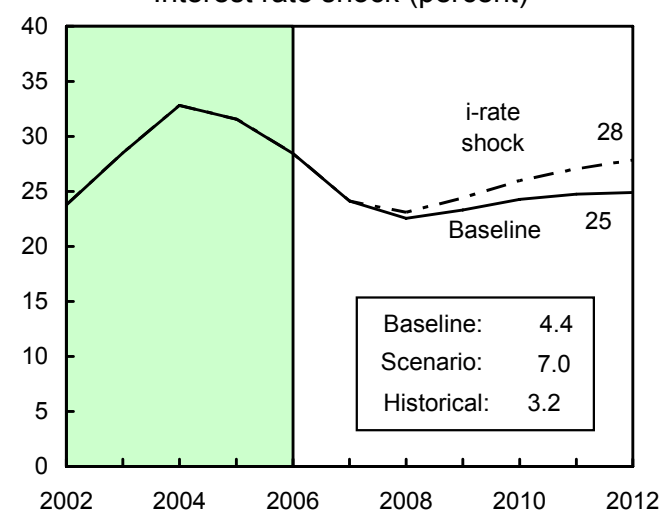

Primary balance shock (in percent of GDP) and no policy change scenario (constant primary balance)

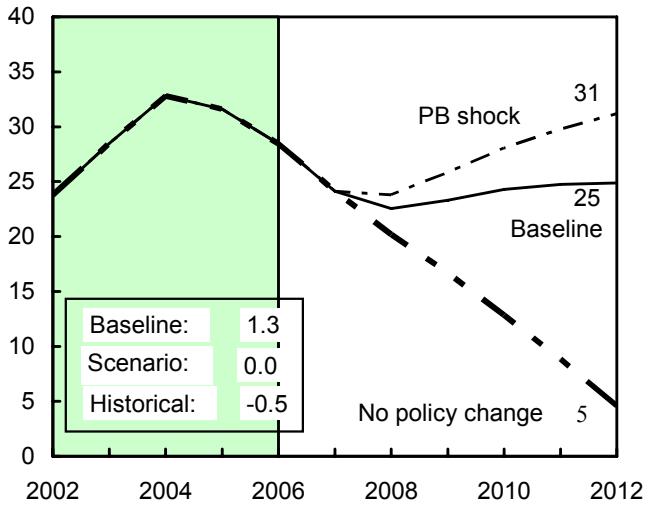

Real depreciation and contingent liabilities shocks ${ }^{3}$

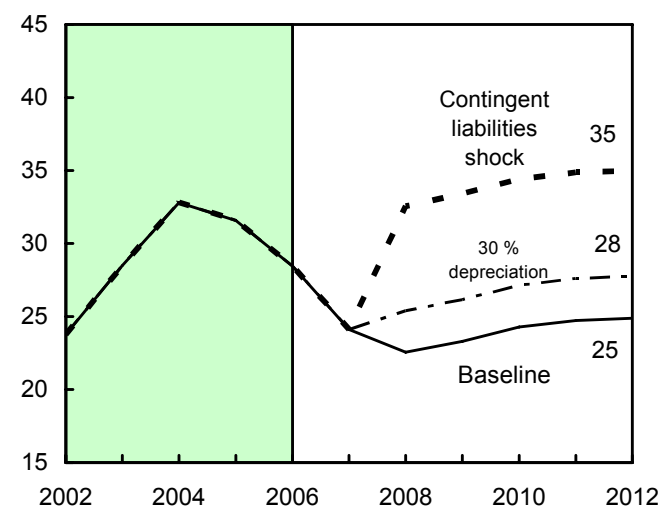

Sources: IMF staff estimates.

${ }^{1}$ Shaded areas represent actual data. Individual shocks are permanent one-half standard deviation shocks. Figures in the boxes represent average projections for the variables in the baseline and scenario presented. Ten-year historical average for the variable is also shown.

${ }^{2}$ Permanent $1 / 4$ standard deviation shocks applied to real interest rate, growth rate, and primary balance.

${ }^{3}$ One-time real depreciation of 30 percent and 10 percent of GDP shock to contingent liabilities occur in 2008, with real depreciation defined as nominal depreciation (measured by percentage fall in dollar value of local currency) minus domestic inflation (based on GDP deflator). 


\section{INTERNATIONAL MONETARY FUND}

EXTERNAL

Public Information Notice

RELATIONS

DEPARTMENT

Public Information Notice (PIN) No. 08/18

FOR IMMEDIATE RELEASE

February 15, 2008

Corrected: 2/19/08
International Monetary Fund

$70019^{\text {th }}$ Street, NW

Washington, D. C. 20431 USA

\section{IMF Executive Board Concludes 2007 Article IV Consultation with Namibia}

On January 18, 2008 the Executive Board of the International Monetary Fund (IMF) concluded the Article IV consultation with Namibia.1

\section{Background}

Namibia's real GDP has remained robust, broadly matching regional peers. For 2007, a modest strengthening of real GDP growth in part reflects buoyant diamond production. Namibia's external current account surplus has risen to high levels in 2006 and 2007, reflecting strong diamond exports, high global prices for other mineral exports, and large receipts from the Southern African Customs Union (SACU). Namibia's strengthened balance of payments position has accommodated a doubling of its international reserves since 2005. Portfolio and other capital investments abroad have also remained at high levels.

Inflation pressures intensified through the first half of 2007, reflecting increases in global food prices. After rising 7.2 percent in the year to July 2007, inflation declined to 6.6 percent in the year through October 2007. Consistent with Namibia's currency peg to the rand, the Bank of

\footnotetext{
${ }^{1}$ Under Article IV of the IMF's Articles of Agreement, the IMF holds bilateral discussions with members, usually every year. A staff team visits the country, collects economic and financial information, and discusses with officials the country's economic developments and policies. On return to headquarters, the staff prepares a report, which forms the basis for discussion by the Executive Board. At the conclusion of the discussion, the Managing Director, as Chairman of the Board, summarizes the views of Executive Directors, and this summary is transmitted to the country's authorities. This PIN summarizes the views of the Executive Board as expressed during the January 18, 2008 Executive Board discussion based on the staff report.
} 
Namibia has, except for the rate increase in December 2007, matched interest rate increases by the South African Reserve Bank, with an increase of 350 basis points since early 2006. Namibia's exchange rate was broadly stable, in nominal effective terms, in 2007.

The fiscal balance moved into surplus in the fiscal year 2006/07 (ending March 31, 2007), reflecting tight expenditure management and strong SACU receipts. Based on a further fiscal surplus projected for $2007 / 08$, public debt should fall below the government's target ceiling of 25 percent of GDP.

\section{Executive Board Assessment}

Executive Directors commended the authorities' sound macroeconomic management, which, together with a favorable external environment, has led to robust economic growth, subdued inflation, large current account surpluses, and a strengthened foreign reserve position. Directors also welcomed the progress toward achieving the Millennium Development Goals, while noting that much remains to be done to lower the high unemployment and poverty rates and the economy's vulnerability to shocks.

Directors noted that the overall outlook for Namibia is positive. Potential downside risks arise mainly from uncertainties regarding the global environment and slow progress in economic diversification. In particular, the key mining sector is vulnerable to a deterioration in the terms of trade. Directors also stressed that reforms to accelerate growth in the non-mineral sectors of the economy will be crucial to reduce unemployment and poverty. They emphasized the importance of further progress in addressing the HIVIAIDS pandemic. Directors encouraged the authorities to take advantage of the current favorable economic climate to build the necessary political support for key pending reforms.

Directors considered that the exchange rate peg to the South African rand remains appropriate. They stressed the importance for policy interest rate differentials with South Africa to be limited to levels that do not destabilize capital flows or official reserves. Directors were of the view that, despite large current account surpluses, there is no evidence of significant currency undervaluation.

Directors commended the authorities for their continuing sound fiscal policies. They welcomed the decision to use part of the recent strong receipts from the Southern African Customs Union (SACU) to reduce public debt through fiscal surpluses. Directors agreed that Namibia's strengthened fiscal position and the projected decline in public debt creates fiscal space for additional expenditure to upgrade infrastructure. Directors stressed, however, that improved expenditure prioritization is needed within the context of the new medium-term expenditure framework. They noted that personnel expenditure remains high by regional standards, and should be reduced in the context of a comprehensive reform of the civil service. Directors 
underlined the importance of reducing risks to the budget through strengthened oversight of public enterprises, and commended the approval of the State-Owned Enterprise Act while urging quick action to bring the Act into effect.

Directors welcomed the authorities' intention to strengthen tax administration and increase revenue collection from the non-mining sectors, noting the importance of maintaining fiscal sustainability in light of the projected decline in SACU receipts over the medium term. Directors attached high priority to strengthening the Inland Revenue Department, including by building its audit capacity, establishing a large-taxpayers' office, and improving administration of the value added tax.

Directors welcomed the favorable performance of the financial sector and the progress in strengthening regulatory oversight in line with FSAP recommendations. They encouraged efforts to foster competition in the banking sector. Directors noted that the authorities' intention to require higher levels of domestic investment by the pension and insurance industries should be carried out in a way that ensures that financial institutions can continue to invest safely and productively in order to generate favorable returns for savers. They welcomed the authorities' intention to implement any reforms to the regulatory regime cautiously, and to closely monitor the financial sector impact while working to broaden the range of domestic investment options.

Directors placed particular emphasis on reforms to reduce unemployment and poverty. They welcomed steps to strengthen labor relations through arbitration and conciliation services, and the plans to promote labor productivity and upgrade civil service skills. They encouraged the authorities to consider also further initiatives to liberalize the trade regime, improve the business environment, and speed up education reform to rapidly narrow the skills gap. Directors emphasized the importance of improving governance, and encouraged the authorities to join the Extractive Industries Transparency Initiative.

Public Information Notices (PINs) form part of the IMF's efforts to promote transparency of the IMF's views and analysis of economic developments and policies. With the consent of the country (or countries) concerned, PINs are issued after Executive Board discussions of Article IV consultations with member countries, of its surveillance of developments at the regional level, of post-program monitoring, and of ex post assessments of member countries with longer-term program engagements. PINs are also issued after Executive Board discussions of general policy matters, unless otherwise decided by the Executive Board in a particular case. 
Namibia: Selected Economic Indicators

\begin{tabular}{|c|c|c|c|c|}
\hline & 2004 & 2005 & 2006 & 2007 Est. \\
\hline & \multicolumn{4}{|c|}{ (Percent) } \\
\hline Change in real GDP & 6.6 & 4.8 & 4.1 & 4.4 \\
\hline \multirow[t]{2}{*}{ Change in CPI (end of period) } & 4.3 & 3.5 & 6.0 & 6.7 \\
\hline & \multicolumn{4}{|c|}{ (Percent of GDP) } \\
\hline Overall fiscal deficit/surplus ${ }^{1}$ & -3.4 & -0.5 & 3.4 & 2.6 \\
\hline \multirow[t]{2}{*}{ Public debt ${ }^{1}$} & 33.7 & 30.2 & 28.2 & 22.8 \\
\hline & \multicolumn{4}{|c|}{ (End of period; percent change) } \\
\hline Broad money & 16.2 & 9.7 & 29.8 & 18.8 \\
\hline \multirow[t]{2}{*}{ Credit to the private sector } & 19.4 & 20.1 & 14.7 & 11.2 \\
\hline & \multicolumn{4}{|c|}{ (Percent of GDP, unless stated otherwise) } \\
\hline Current account balance & 8.2 & 5.5 & 15.9 & 18.5 \\
\hline International reserves (months of imports) & 1.7 & 1.4 & 2.1 & 2.8 \\
\hline Exchange rate (Namibia dollar/U.S. dollar, end of period) & 5.6 & 6.3 & 7.0 & 6.8 \\
\hline
\end{tabular}

Sources: Namibian authorities; and IMF staff estimates.

${ }^{1}$ Figures are for fiscal year, which begins April 1. 


\section{Statement by Peter Gakunu, Executive Director for Namibia and Ebson Uanguta, Advisor to Executive Director \\ January 18, 2008}

The Namibian authorities appreciate the Fund's engagement and support for their economic program. They value the candid exchange of views with staff during the 2007 Article IV Consultation. They find the staff report informative, well balanced and containing useful analyses and advice on the country's economic policies, challenges, and prospects.

\section{Economic Performance ANd Prospects}

The Namibian authorities have continued to maintain sound macroeconomic management, which coupled with favorable external conditions, has sustained the economic growth in line with that of its CMA/SACU regional partners. The economy recorded robust growth, moderate inflation and strong external surpluses in 2006. Real GDP grew by 4.1 percent in 2006 led by growth in diamond, telecommunications, retail trade and financial sectors. GDP in 2007 is projected to grow by around 4.0 percent, and is expected to hover around 4.5-5 percent in the medium-term, underpinned by continued strengthening of the nonmining sector, including tourism initiatives. Notwithstanding the good performance, key downside risks to the economy include the possibility of a more rapid decline in onshore diamond mining than projected and weather-related shocks to agricultural production. Nevertheless, the authorities are ready to take suitable measures to address these challenges.

While inflation moderated at 5.1 percent during 2006, it increased in the beginning of the first quarter of 2007 mainly due to high food prices. However, it declined to 6.6 percent in October 2007 from a peak of 7.2 percent reached in July 2007, and is expected to moderate to 6 percent in 2008, due in part to sustained tightening of monetary policy.

The external current account surplus rose to 15.9 percent of GDP in 2006 from 5.5 percent in 2005, due to strong export performance supported by high commodity prices, and significant increase in SACU revenue inflows. The exchange rate has been stable in nominal effective terms in the 12 months through September 2007, and real effective exchange rate in the first nine months of 2007 was in line with the average for the preceding decade.

\section{Fiscal Policy}

The country's fiscal stance continues to remain prudent. Total revenue as a percent of GDP rose from 31.5 percent in 2005 to 36.3 percent in 2007. Enhanced revenue is attributed to mineral export taxes and SACU receipts that contributed to a fiscal surplus of 2.1 percent of GDP in 2006/07. However, the fiscal surplus is projected to decline to about 1.1 percent of GDP in 2007/08 fiscal year because of increased public spending to revamp key 
infrastructure and reduce public debt. In this respect, public debt would be reduced to an estimated 23 percent of GDP by mid-2008 from 28 percent in 2006/07. The authorities are committed to improving spending priorities, increasing fiscal space, and further reducing public debt.

The Namibian authorities are also committed to strengthening revenue collection. SACU currently accounts for more than one-third of total revenue. Given the temporary nature of SACU windfall/receipts, the authorities consider that a broad-based and effective domestic tax system capable of generating increased revenue needs further consolidation.

On the expenditure side, the authorities are taking advantage of the favorable fiscal situation to implement public expenditure reforms, aimed at accelerating growth and poverty reduction. The authorities recognize that state-owned enterprises continue to drain budgetary resources. In this regard, the adoption of the new SOE Governance Act, aimed at strengthening corporate governance in these enterprises, is an important development in the right direction. This would further strengthen SOE's performance, reduce quasi-fiscal activities and risks to the budget, and create more fiscal space. It is also important to note that the wage bill has declined to 13 percent of GDP in 2006/07 from 15 percent three years ago.

\section{Monetary And Exchange Rate Policy}

The authorities continue to be committed to the CMA arrangement as an appropriate monetary framework. Within the CMA, the Namibian currency is pegged to the Rand (1:1), and inflation and interest rates are aligned. While the country's macroeconomic conditions have been diverging in some instances from those of South Africa, the authorities still consider CMA as an appropriate framework for ensuring medium to long run price stability. The country's level of reserves has reached a robust level, covers adequately short-term external debt, and represents more than 3 months of imports cover. This is a significant achievement for the country, thanks to improved export performance, better than expected SACU receipts and the authorities' strong commitment to fiscal consolidation.

\section{FINANCIAL SECTOR}

The financial sector is profitable and well capitalized. In line with the FSAP recommendations, the authorities have taken steps to strengthen both banking and non-banks financial institutions. Though the sector is well regulated, a number of refinements have been issued recently, including amendments to the Banking Act mandating consolidated supervision which is expected to be promulgated by mid-2008. Furthermore, progress has been made towards risk-based supervision, with priority being given to on-site visits to potentially higher risk financial institutions to strengthen the sector.

While access to Namibia financial system remains limited, significant progress has been made over the past years to widen and deepen financial intermediation. To this end, banks 
and other financial institutions are making efforts to reach out to poorer households and small and medium-sized enterprises, including through innovative products like mobile banking, merchant-serviced ATMs, smart cards, lower-fee savings accounts, and micro-lending products that do not require collateral. Banks are also extending services to rural areas in the wake of road and power infrastructure connections. One of the local commercial banks established a smart partnership with the Post Savings Bank, which has widespread network in the rural areas, as a strategy to improving access to banking services by rural households.

The preparation of the country's financial sector charter that is under way and which is to be launched in the first half of 2008, is expected to add more impetus to access and intermediation efforts.

The authorities have strengthened anti-money laundering policies and enacted Financial Intelligence Act in 2007. A financial intelligence center has been established within the Central Bank of Namibia, and appropriate regulations would be finalized in due course. The authorities are now at the level of identifying and analyzing training needs and the roles of the respective government agencies in this undertaking.

\section{STRUCTURAl Challenges AND Risks}

The regulatory measures on domestic asset requirements, considered by the authorities, are aimed at reducing the 35 percent of domestic qualifying assets for dual-listed companies gradually over a five-year period. Even though Namibia has one of the highest gross national savings rate in sub-Saharan Africa in terms of pension funds and long term insurance, the country has not been able to fully benefit and utilize this capital for the much needed and broad-based economic development. The funds continue to flow out of the country, via duallisted companies. In this regard, the regulatory measures being contemplated would tighten domestic investment requirements for the dual-listed companies, with the view to encouraging retention of these resources for domestic investment. The authorities, aware of possible distortionary effect of the intended measures, have already started conducting research on possible investment instruments, and are encouraging the development of appropriate market based instruments. They are considering developing a framework for monitoring the likely impact on financial sector risk and returns. As a strategy to broadening the range of investment options, the authorities have been actively encouraging SOE with financial soundness to consider issuing bonds in the local market.

Fostering employment growth in the non-mining sectors to reduce unemployment remains a key priority of the Namibian authorities, who view economic diversification from the mineral sector to non-mineral manufacturing, tourism and other services as a significant step in reducing high unemployment. In this regard, they are committed to continue to create a conducive environment and putting in place measures to increase competitiveness, through improved skills and labor productivity. The government efforts of diversification have started 
bearing fruits as reflected by a growing number of diamond cutting and polishing companies established over the past 3 years.

Strengthening the health sector, in particular the fight against HIV/Aids pandemic, continues to remain a priority of government. The decline in Namibia's HIV prevalence rate from 22 percent in 2002 to 20 percent in 2006, has largely been attributed to the National Awareness Campaign run jointly by the government, private sector and international agencies. The program of public provision of antiretroviral (ART) drugs launched in 2003 currently covers about 40,000 patients or about 70 percent of those who could benefit from ART treatment. The improved fiscal space has enabled the authorities to allocate adequate resources to this priority area.

The Namibian authorities continue to put in place measures to strengthen business environment, including effective public services delivery. The World Bank's Doing Business 2008 survey ranked Namibia 43 out of 178 countries, with the country rated positively by business in a number of areas, including licensing framework and enforcing contracts. To improve effectiveness and skill levels in the civil service, the authorities will be launching a National Institute of Public Administration and Management in 2009. Measures to improve the overall quality of education under the Government Education Sector Improvement Programme (ETSIP), have been put in place.

The authorities have launched a Third National Development Plan, which serves as a key framework for implementing the country's development policies for sustained growth and poverty reduction. They are also of the view that criteria for concessional borrowing eligibility should be revisited to enable countries with high income inequality and widespread poverty better access to these facilities. In the new NDP3, efforts are under way to implement program-based budgeting to help improve accountability and help prioritize government expenditures.

\section{CONCLUSION}

The Namibian authorities remain committed to implementing prudent and sound policies, which they consider as key for accelerating growth, reducing unemployment and poverty. The authorities appreciate and continue to rely on the Fund's advice on areas of interest to the country's policy challenges, including better utilization of retained capital under Regulation 28 and $15^{1}$ to promote domestic investment. They also trust that the Fund and the international community would support their request to be considered for concessional borrowing, given the country's high income inequality and widespread poverty.

\footnotetext{
${ }^{1}$ Regulation 28 and 15 are provisions that allow Namibia to retain part of the Pension and Long term Insurance Funds to be invested in the domestic assets.
} 